\begin{abstract}
UNIVERSIDADE DE SÃO PAULO
FACULDADE DE FILOSOFIA, LETRAS E CIÊNCIAS HUMANAS DEPARTAMENTO DE LETRAS MODERNAS

PROGRAMA DE PÓS-GRADUAÇÃO EM LÍNGUA E LITERATURA

ITALIANA
\end{abstract}

FRANCISCO JOSÉ SARAIVA DEGANI

\title{
Pirandello "novellaro": da forma à dissolução
}

São Paulo

2008 


\section{UNIVERSIDADE DE SÃO PAULO \\ FACULDADE DE FILOSOFIA, LETRAS E CIÊNCIAS HUMANAS DEPARTAMENTO DE LETRAS MODERNAS \\ PROGRAMA DE PÓS-GRADUAÇÃO EM LÍNGUA E LITERATURA ITALIANA}

\section{Pirandello "novellaro": da forma à dissolução.}

Francisco José Saraiva Degani

Dissertação apresentada ao Programa de PósGraduação em Língua e Literatura Italiana do Departamento de Letras Modernas da Faculdade de Filosofia, Letras e Ciências Humanas da Universidade de São Paulo, para a obtenção do título de Mestre em Letras.

Orientador: Profa. Dra. Lucia Wataghin

São Paulo

2008 


\section{AUTORIZO A REPRODUÇÃO E DIVULGAÇÃO TOTAL OU PARCIAL DESTE TRABALHO, POR QUALQUER MEIO CONVENCIONAL OU ELETRÔNICO, PARA FINS DE ESTUDO E PESQUISA, DESDE QUE CITADA A FONTE.}

Degani, Francisco José Saraiva

Pirandello "novellaro": da forma à dissolução / Francisco José Saraiva Degani; orientador Lucia Wataghin

-- São Paulo, 2008.

$131 \mathrm{f}$.

Dissertação (Mestrado - Programa de Pós-graduação em Língua e Literatura Italiana. Área de concentração: Literatura Italiana) - Faculdade de Filosofia, Letras e Ciências Humanas da Universidade de São Paulo.

1. Novelle per un anno. 2. Luigi Pirandelo. 3. Literatura italiana - novela. 4. Início do século XX. 


\section{FOLHA DE APROVAÇÃO}

Francisco José Saraiva Degani

Pirandello "novellaro": da forma à dissolução

Dissertação apresentada à Faculdade de

Filosofia, Letras e Ciências Humanas da Universidade de São Paulo para obtenção do título de Mestre.

Área de Concentração: Literatura Italiana

Aprovado em:

Banca Examinadora

Prof. Dr.:

Instituição: Assinatura:

Prof. Dr.:

Instituição: Assinatura:

Prof. Dr.:

Instituição: Assinatura: 
DEDICATÓRIA

Ao outro Luigi. 


\section{AGRADECIMENTOS}

À Profa. Dra. Lucia Wataghin, por esta e outras oportunidades.

Aos professores, familiares e amigos que não permitiram que eu perdesse o fôlego na longa jornada que foi chegar até aqui.

Sinceramente. 


\section{RESUMO}

DEGANI, F. Pirandello "novellaro": da forma à dissolução. 2008. 131 f. Dissertação (Mestrado) - Faculdade de Filosofia, Letras e Ciências Humanas, Universidade de São Paulo, São Paulo, 2008.

Estudar a obra novelística de Luigi Pirandello é um modo de entender não apenas as razões que o levaram a ser um dos mais importantes escritores italianos do século XX, mas também o papel de cada um de nós no mundo e na vida. As novelas, baseadas em pequenos acontecimentos cotidianos, formam um grande mosaico da existência humana: uma nota no jornal, um amor acabado ou ainda nem começado, um simples gesto ou o apito de um trem, são situações que despertam a imaginação do autor e nas quais muitas vezes nos reconhecemos. Dramaturgo e romancista de sucesso, Pirandello nunca deixou de escrever novelas: foram 251 ao longo de sua carreira. Para ele, a novela era o espaço íntimo, insubstituível, reservado para a discussão existencial empreendida pelos seus personagens em uma época tão inquieta como o início do século XX. As novelas, reunidas no projeto Novelle per un anno, são de vital importância para se compreender a evolução das preocupações do autor e representam a base de seu pensamento. As últimas novelas, principalmente, trazem novas chaves de interpretação ao conjunto da obra e mostram um escritor novo e muito mais inquietante, que muitas vezes a crítica não soube reconhecer. Traçar a trajetória do Pirandello novelista, ou "novellaro", como ele se definia, relacionando-a com os outros aspectos de sua carreira literária, de seu pensamento e da época que ele tão bem retratou, é o objetivo deste trabalho.

Palavras chave: 1 . Novelle per un anno. 2. Luigi Pirandello. 3. Literatura italiana - novela. 4. Início do século XX. 


\section{ABSTRACT}

DEGANI, F. Pirandello "novellaro": from form to dissolution. 2008. $131 \mathrm{f}$. Dissertation (Master) - Faculdade de Filosofia, Letras e Ciências Humanas, Universidade de São Paulo, São Paulo, 2008.

To study Pirandello's short story is a means not only of understanding the reason why he became one of the most important Italian writers of the twentieth century but also the role we play in the world and life. His short stories, based on ordinary events, make the great mosaic of our lives - a piece of news, a love that has broken up or not even started, a gesture, a train whistle; situations that drive his thoughts, where many times we recognize ourselves. Successful play writer and novelist, Pirandello never stopped writing short stories: 251 along all his work life. According to Pirandello, a short story was the intimate, unique place, intended for the existential debates of his characters in the hard times of the beginning of the twentieth century. The short stories, brought together in the project Novelle per un anno, are of great importance to understand the evolution of the author's worries and represent the basis of his thought. The last short stories mainly bring new tools for interpretation to Pirandello's work and show a new, much more disturbing writer, many times not acknowledged by critics. To follow the course of the short-story writer Pirandello - or novellaro, as he used to call himself - connected with other aspects of his literary life, thought, and the time he described so well, is the focus of this work.

Keywords: 1. Novelle per un anno. 2. Luigi Pirandello. 3. Italian literature - short story. 4. Beginning of the twentieth century. 


\section{ABSTRACT}

DEGANI, F. Pirandello “novellaro": dalla forma alla dissoluzione. 2008. $131 \mathrm{f}$. Tesi

(Master) - Faculdade de Filosofia, Letras e Ciências Humanas, Universidade de São Paulo, São Paulo, 2008.

Studiare l'opera novellistica di Luigi Pirandello è utile per capire non solo le ragioni che lo hanno portato ad essere uno dei più importanti scrittori italiani del Novecento, ma anche il ruolo di ognuno di noi nel mondo e nella vita. Le novelle, basate su piccole vicende quotidiane, formano un grande mosaico della nostra vita: una nota sui giornali, un amore finito o non ancora cominciato, un semplice gesto o il fischio del treno, sono situazioni che fanno scattare la riflessione dell'autore e in cui spesso ci riconosciamo. Commediografo e romanziere di successo, Pirandello non smise mai di scrivere novelle: 251 lungo l'arco di tutta la sua carriera. Per lui la novella era lo spazio intimo, insostituibile, riservato alla discussione esistenziale intavolata dai suoi personaggi in un'epoca inquieta come l'inizio del XX secolo. Le novelle, raccolte sotto il titolo Novelle per un anno, sono d'importanza vitale per capire l'evoluzione delle preoccupazioni dell'autore e rappresentano la base del suo pensiero. Soprattutto le ultime novelle portano nuove chiavi d'interpretazione all'insieme dell'opera e rivelano uno scrittore del tutto nuovo e molto più inquietante, che spesso la critica non ha saputo riconoscere. Tracciare l'itinerario del Pirandello novelliere, o "novellaro" come lui si definiva, in rapporto con altri aspetti della sua carriera letteraria, del suo pensiero e dell'epoca che ha ritrattato così bene, è l'oggetto di questo lavoro.

Palavras chave: 1 . Novelle per un anno. 2. Luigi Pirandello. 3. Letteratura italiana - novella. 4. Inizio del XX secolo. 


\section{Notas de Leitura}

- Neste trabalho foram utilizadas as indicações das "Diretrizes para apresentação de dissertações e teses da USP: documento eletrônico e impresso" disponível no endereço eletrônico http://www.teses.usp.br/info/diretrizesfinal.pdf.

- A referência bibliográfica está de acordo com a normalização International Standard Organization (ISO) - ISSO 690 e ISO 690.2, exceto no que se refere ao nome das novelas que são apresentados entre aspas (“"), pois muitas deles referem-se também a livros do autor estudado (que é apresentado em itálico).

- A data entre parêntesis, junto ao nome de cada novela citada, refere-se ao ano da primeira publicação, pois não há dados suficientes para identificar com certeza o ano em que cada uma delas foi escrita.

- Após a data acima citada, aparece uma sigla, com um ou dois caracteres, que indica em qual volume das Novelle per un anno a referida novela se encontra. As siglas são as seguintes:
(A) - Appendice;
(BG) - vol. XIV. Berecche e la guerra;
(B) - vol. XIII. Candelora;
(DM) - vol. IX. Donna Mimma;
(G) - vol. XI. La giara;
(IS) - vol. VI. In silenzio;
(M) - vol. V. La mosca;
(NC) - vol. VIII. Dal naso al cielo;
(R) - vol. III. La rallegrata;
(SN) - vol. I. Scialle nero;
(TE) - Testi estravaganti.
(TT) - vol. VII. Tutt'e tre;
(UG) - vol. XV. Una giornata;
(US) - vol. IV. L'uomo solo;
(V) - vol. XII. Il viaggio;
(VD) - vol. X. Il vecchio Dio;
(VN) - vol. II. La vita nuda. 
Nota de tradução: Apenas os textos escritos por Luigi Pirandello são citados no original italiano, com tradução em nota de rodapé. Os demais textos de outros autores aparecem já traduzidos no corpo do trabalho. Todas as traduções são de minha autoria, exceto quando indicado o contrário em nota. 

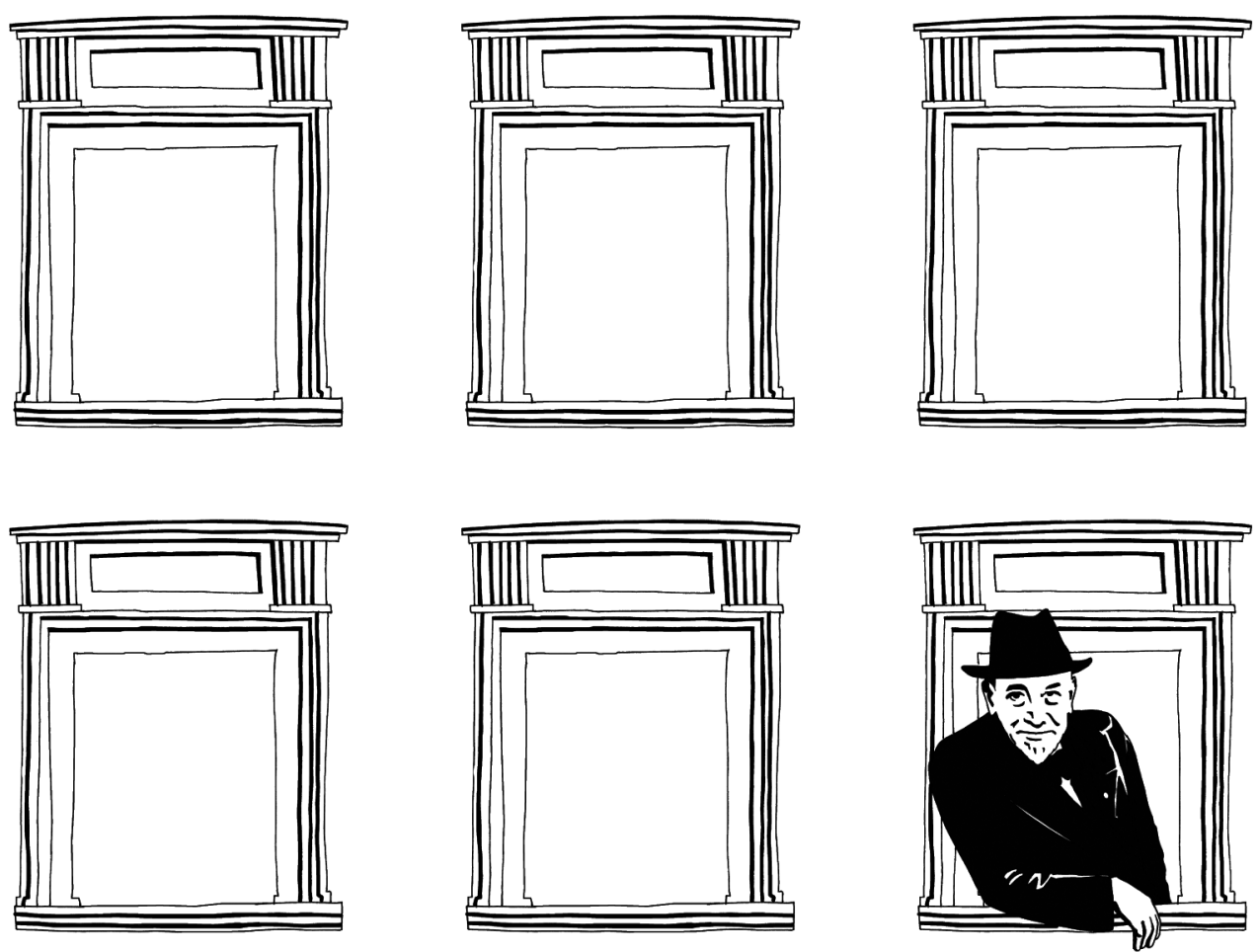

Pirandello "novellaro": da forma à dissolução 


\section{Sumário}

Introdução

1. Pirandello e sua época.

2. Vida e arte: três momentos na poética de Pirandello.

2.1. O contato com o mundo.

2.2. À procura de uma explicação: vida e forma.

2.3. A realidade “outra".

3. Pirandello "novellaro".

4. As Novelle per un anno.

4.1. Estrutura.

4.2. Personagens e conteúdo.

4.3. As últimas novelas.

5. A jornada final.

5.1 Temática.

5.2 Língua e estilo.

5.3. A dissolução da forma.

Considerações finais

Referências bibliográficas

Anexo 1: Gráfico - Número de novelas publicadas por ano.

Anexo 2: Novelas publicadas entre 1931 e 1936.

Anexo 3: Bio-bibliografia - Pirandello "novellaro". 
Per me si va nella città dolente

Per me si va nell'eterno dolore

Per me si va tra la perduta gente

Dante Alighieri. La Divina Commedia, Inferno, III, 1-3 


\section{Introdução}

Escritor, dramaturgo, poeta e ensaísta, o siciliano Luigi Pirandello (1867-1936) é um dos mais importantes autores italianos do século XX. Mais conhecido, na Europa e no mundo, por sua obra teatral, Pirandello foi autor de uma rica obra novelística à qual sempre se dedicou, desde as primeiras novelas ${ }^{1}$ publicadas em 1894 , no volume Amori senza amore, até sua morte em 1936

É considerado um escritor isolado, difícil de enquadrar em um movimento literário bem definido e suas obras nos levam a refletir sobre a existência humana, o mal de viver e o papel do homem na sociedade.

Substancialmente, as novelas ocupam todo o arco da produção de Pirandello, e representam o testemunho direto de suas preocupações nas diversas fases da carreira. Entetanto, não se atribui a estas novelas uma importância comparável à de suas obras teatrais ou romances. Pirandello é reconhecido, em primeiro lugar, como dramaturgo, em segundo como romancista, e apenas em última instância como novelista.

A crítica, que em geral está mais interessada na obra teatral de Pirandello, trata as novelas como uma espécie de grande "reservatório" dos temas desenvolvidos nos romances e

\footnotetext{
${ }^{1} \mathrm{Na}$ falta de um termo adequado em português, utilizo o termo novela para nomear o tipo de narrativa breve usado por Pirandello na sua obra em prosa, bem como a novela italiana no sentido boccacciano. As características deste tipo de narrativa serão discutidas adiante.
} 
no teatro, sem levar em conta que a obra de um autor não pode ser avaliada por apenas um ângulo.

A obra de Pirandello, sobretudo, apresenta relações internas auto referenciadas entre os gêneros por ele cultivados e as novelas, assim como a poesia, os romances e as peças teatrais, fazem parte de um sistema global em que os temas podem (e devem) ser estudados em conjunto, não havendo razão para se determinar qual seria o gênero mais ou menos importante.

$\mathrm{Na}$ maioria dos casos, a crítica reserva um grande espaço para a dramaturgia pirandelliana e quando se refere à novelística o faz "de passagem", apenas observando os pontos que interessam à dramaturgia. Com poucas exceções, estudam-se apenas algumas novelas, quase sempre as mesmas, sendo que a primeira produção (1894-1904) é praticamente ignorada; a novelística da época mais produtiva (1904-1920) é parcialmente avaliada, sobretudo em função de sua contribuição para temas e personagens desenvolvidos no teatro; as novelas finais (1930-1936) que, além de serem poucas, são consideradas atípicas, são tratadas separadamente e de maneira quase sempre superficial, descritiva, são completamente dissociadas do contexto da obra, e relacionadas apenas às peças consideradas "míticas".

As novelas, compostas com assiduidade, foram publicadas de maneira esparsa em jornais, revistas e pequenos volumes. Em 1922, seguindo a experiência da publicação de suas obras teatrais, reunidas em volume com título geral de Maschere Nude, Pirandello decide reordenar toda sua produção novelística em um projeto unitário que recebe o título de Novelle per un anno, e visa reunir a obra em 24 volumes, com 15 novelas cada um, compondo um total de 365 novelas, legitimando, assim, o nome do projeto. A morte do autor, no entanto, 
frustrou seu objetivo: apenas 15 dos 24 volumes foram publicados, sendo que o último volume, Una giornata, saiu póstumo em 1937.

A organização das Novelle per un anno, por não ter uma ordenação facilmente reconhecível, talvez tenha dificultado um pouco o trabalho da crítica que, em sua maioria, optou por não fazer relações entre temas, cronologia e personagens, preferindo eleger algumas das novelas como representativas do pensamento do escritor e se deter nelas. Na tentativa de dar ordem ao "caos pirandelliano", acabou-se privilegiando aquelas novelas que, de alguma forma, contribuíram para a confecção das peças teatrais e, por este motivo, foi criada a idéia de "reservatório".

As novelas discutem e refletem as preocupações do autor sobre a condição humana, sobretudo em função da sociedade e das instituições de sua época, e seu ensaísmo as completa de modo decisivo, servindo de comentário crítico sobre o exposto narrativamente. São notáveis os ensaios Arte e scienza, de 1901, e L'Umorismo, de 1908, que, além de comentar a obra narrativa, representam seu fundamento teórico. A maturação das idéias contidas nestes ensaios, principalmente no segundo, acompanham a evolução da narrativa do autor e a orientam.

Examinar a novelística de Pirandello sem destacá-la do conjunto da obra, mostrando as inter-relações e os contatos com o restante da produção (poesia, ensaísmo, dramaturgia e romance), parece ser uma alternativa viável para resgatar a importância e centralidade da narrativa curta na evolução do pensamento do escritor. Menos sujeitas a pressões da crítica e do público, as novelas permitiram um exercício de escrita mais livre, mais reflexivo, mais conectado com seu tempo, menos controlado, porém não menos empenhado. Os temas tratados são mais urgentes e ligados às modificações sociais, políticas e econômicas do início 
do século XX que condicionaram a evolução de obra e a experiência de Pirandello. Permitem um minucioso estudo do homem de seu tempo, elevando-o a paradigma da existência humana. Assim, resgatar e estudar a obra novelística de Pirandello, conectando-a à trajetória literária e de vida do autor, é um modo de entender não apenas as razões que o levaram a ser um dos mais importantes escritores italianos do século $\mathrm{XX}$, mas também o conjunto de sua obra, seu pensamento, esperando abrir caminho para novos e melhores estudos. 


\section{Vida e arte: três momentos na poética de Pirandello.}

A obra de Luigi Pirandello é bastante considerável, compreendendo 5 livros de poesia, sete romances, 251 novelas e mais de quarenta obras teatrais, além de algumas (poucas) incursões no cinema, ${ }^{2}$ arte que nasceu no início do século XX. Essa produção espalha-se ao longo dos seus 69 anos de vida, ou melhor, dos 52 anos decorridos desde a publicação de sua primeira novela em 1884, a já citada "Capannetta"(1884, A), até a publicação de sua última novela, "Effetti di un sogno interrotto" (1936, UG), no dia anterior à sua morte, em dezembro de 1936.

A concepção de vida e arte de Pirandello está estreitamente ligada à realidade sóciocultural do homem de sua época, e decorre mais da observação exaustiva dos fatos do que de uma posição filosófica consciente do autor. Certamente essa concepção recebeu a influência de Giacomo Leopardi, principalmente no que se refere às vãs presunções e à mesquinhez dos homens, mas também da educação universitária alemã do autor, que deu às alucinantes narrativas do siciliano uma profundidade e amplitude de introspecção e um domínio lógico preciso que as universalizam, levando-o a analisar, sobretudo em suas novelas, casos às vezes absurdos como forma de retratar o sofrimento humano.

\footnotetext{
${ }^{2}$ Entre outros, escreveu o roteiro do filme Acciaio (1933), encomendado pelo governo fascista, adaptou para o cinema a peça Come tu mi vиoi (1930), filmada nos Estados Unidos com Greta Garbo no papel principal, e chegou a iniciar o roteiro para o cinema do drama Sei personaggi in cerca d'autore.
} 
Em sua obra narrativa e teatral, vida e arte se confundem, examinam e influenciam mutuamente, como num processo de amadurecimento que aos poucos leva a uma profunda análise do ser humano e da sociedade de seu tempo. As relações entre o homem e a sociedade são atentamente examinadas pelo autor, que procurou representar as incertezas e angústias do século que se iniciava.

O amadurecimento da obra de Pirandello passa por três momentos marcantes. Em primeiro lugar, ele toma contato com o mundo que o cerca, as pessoas e a realidade como elas se apresentam. Sem se perguntar as razões das coisas, ele as descreve como são, ou como as vê, sem tentar julgá-las ou modificá-las.

Após esse momento de primeiro contato, que na maioria das vezes demonstra-se fonte de desilusão e sofrimento, ele sai em busca de uma explicação, das razões da desilusão, experimentando situações e reagindo de acordo com cada uma delas, tentando encontrar uma saída para o sofrimento humano; sistematiza a poética do humorismo e utiliza o espelho como metáfora da alma humana, o "ver-se viver", para tentar entender a vida que o circunda e da qual ele não é mero espectador.

Por fim, a investigação parece conduzir a uma solução além do tempo e do ambiente. É preciso tentar redimensionar estes fatores, equilibrar suas relações, pois a saída não está aparente, mas algo indica que deve existir. Pirandello parece estar indo na direção certa, mas não há mais tempo para examinar todas as hipóteses que ficam apenas delineadas em uma suspensão da realidade, na temática do "homem só”, da evasão e na poética do silêncio. ${ }^{3}$

\footnotetext{
${ }^{3}$ Curiosamente, a última novela do último volume das Novelle per un anno, "Una giornata" (1935, UG), tem exatamente esta estrutura (contato/busca de razões/a "outra" realidade).
} 


\subsection{O contato com o mundo.}

Ao tomar contato com o mundo, o jovem Pirandello procura entender as relações entre os homens, catalogando-as e descrevendo-as quase como um cientista de história natural, na tentativa de traçar um painel de relacionamentos que permita uma análise do conjunto. A primeira conclusão a que chega é de que as relações humanas são baseadas quase exclusivamente nas aparências, na forma das coisas, e não na realidade de cada um de nós; ou seja, temos um vazio interior que tentamos preencher externamente com nossa aparência. As primeiras novelas de Pirandello, reunidas no volume Amori senza amore (1894), ${ }^{4}$ são os testemunhos iniciais dessa análise.

É uma fase juvenil que vai aproximadamente até a publicação dos romances L'esclusa (1901) e Il turno (1902). ${ }^{5}$ Nessa fase, Pirandello escreve sob a influência dos grandes mestres do Naturalismo, principalmente Émile Zola e os veristas seus conterrâneos, Giovanni Verga e Luigi Capuana. Este último o incentivara a experimentar a narrativa em prosa, deixando gradualmente de lado a poesia (nesta época, Pirandello estava escrevendo as poesias do livro Zampogna, que publicará em 1901). A poesia acrescenta muito pouco à obra de Pirandello podendo ser consideradas um exercício de juventude. Uma tentativa de auto-conhecimento, reunião de idéias e intuições que mais tarde seriam reelaboradas na prosa. Veja-se, por exemplo, a poesia "Padron Dio", publicada no livro Zampogna (1901), mas de composição bem anterior, ${ }^{6}$ que depois foi reelaborada como a novela homônima (1898, UG).

Nesta fase, muito próxima do Verismo de Verga, os personagens são pouco caracterizados, muito parecidos uns com os outros, uniformes e absorvidos pelo ambiente em que circulam, são uma multidão de "vencidos", como em Verga, cada um vivendo uma vida

\footnotetext{
${ }^{4}$ O livro reunia as novelas "L'onda", "L'amica delle mogli" e "La signorina".

${ }^{5}$ Escritos respectivamente em 1893 e 1895.

${ }^{6}$ Zampogna reunia poesias escritas entre 1892 e 1898.
} 
amorfa e sem futuro que é deixada por conta do destino. A diferença em relação ao mundo de Verga é que os personagens pirandellianos não são resignados diante do destino que lhes cabe; eles gesticulam, debatem-se, tentam escapar de várias maneiras, apelando inclusive para a loucura, ou a falsa loucura; não têm um momento de sossego e tentam não se deixar levar pela vida, sempre controlados e vigiados por seus sentimentos. ${ }^{7}$ Mesmo quando alguns desses personagens têm, aparentemente, uma vida pacífica e comum, eles trazem dentro de si um descontentamento, um sofrimento agudo e reprimido que lhes causa grande inquietação. São como molas comprimidas que podem explodir a qualquer momento e arrebentar o mundo que as circunda. Basta um mínimo choque com o mundo, um quase nada para mandar para os ares o ambiente que tenta contê-los. ${ }^{8}$ Em Verga, havia a cumplicidade contida, quase despercebida, do autor para com seus pobres diabos e o destino que os oprimia; em Pirandello, a participação do autor na desdita de seus personagens é evidente, mas é uma cumplicidade áspera e sem doçura, quase um julgamento, que revela um estado de ânimo acusador, polêmico e muitas vezes cruel.

A impossibilidade de explicar porque cada movimento humano parece regulado pelo acaso, que tudo ordena e desagrega caprichosamente, sem uma lei natural ou relação de causa e efeito, diferencia a obra de Pirandello da obra dos que o precederam. Em Verga, por exemplo, e na narrativa Naturalista em geral, o que importa é o "fato", que é causado por um "fato" anterior e causa o "fato" seguinte, em uma cadeia circular fechada, que, mesmo não sendo coerente, obriga o personagem a viver de um determinado modo, a tomar decisões que sejam aceitas pela sociedade.

\footnotetext{
${ }^{7}$ Ver, como exemplo, a já citada novela Padron Dio (1898,.UG)

${ }^{8}$ Ver, como exemplo, a novela Lumie di Sicília (1900, VD).

${ }^{9}$ Por "fato", deve-se entender tanto o fato em si e o personagem que o vive, quanto a condição geral na qual este foi gerado e, por sua vez, gerou as conseqüências.
} 


\section{estrutura circular fechada}

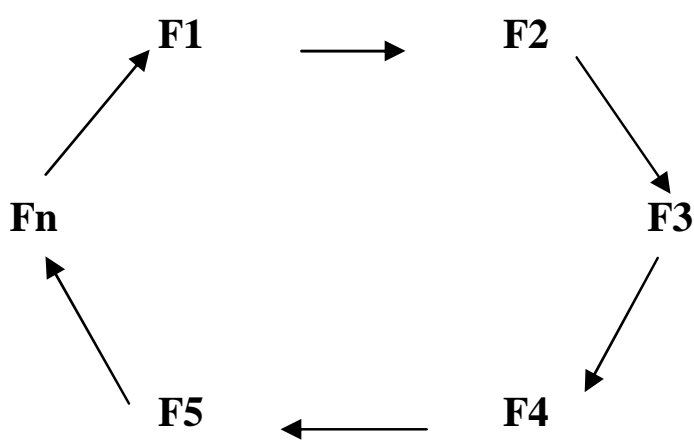

Desde o início de sua produção narrativa, Pirandello tem consciência de que o "fato" não pode ser rigidamente constituído, mas deve ser analisado em suas causas e redimensionado em suas conseqüências. Faz parte de uma estrutura aberta que pode levar a resultados inesperados, dependendo da ação do acaso e da postura do personagem.

\section{estrutura aberta}

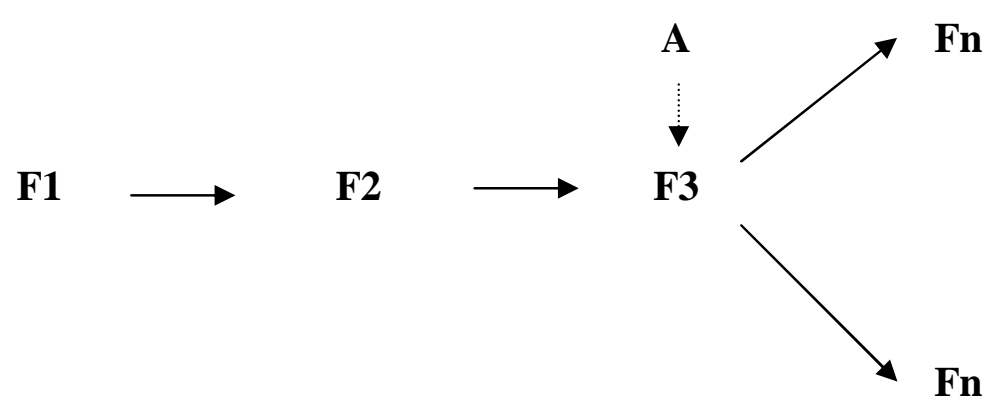

No romance L'esclusa (1901), por exemplo, a protagonista Marta Ajala, é rejeitada pelo marido e pela sociedade, acusada de ter pecado, mas ao pecar de verdade - e esta é uma decisão do próprio personagem que não se conforma com seu destino - é novamente aceita. Serve também como exemplo a novela "Il "fumo" (1901, SN), em que Mattia Scala, rico 
proprietário de terras perde suas posses e, aos poucos, comprando em parcelas as terras de um vizinho, tenta recompor seu patrimônio. O vizinho, no entanto, é assassinado por uma macaca (ação do acaso), e Scala, por não ter os recibos do montante já pago, perde novamente as terras. Sem se conformar, Scala incendeia a casa em que mora e o fogo se alastra por toda a colina que a cerca, destruindo as terras vizinhas sob as quais existia uma jazida de enxofre.

\section{2. À procura de uma explicação: vida e forma.}

Em um segundo momento, é preciso partir em busca de uma explicação, a simples constatação das artimanhas do destino e do acaso não são suficientes para justificar o sofrimento humano: o personagem se rebela e reage contra a vida tentando encontrar uma saída.

Pirandello procura encontrar a origem desse sofrimento e, para tanto, escava a psique humana tentando encontrar uma resposta. Esta busca o leva a examinar todos (ou quase todos) os tipos de relacionamento humano, numa espécie de mapeamento da realidade que, indo além, pura e simplesmente, do âmbito das relações sociais, acaba por se estender à condição do homem no mundo. São os anos da maturidade, em que o contato com os problemas humanos se aprofunda cada vez mais, fazendo com que Pirandello se afaste paulatinamente dos preceitos veristas e dirija sua atenção para a personalidade, a "alma" dos personagens, para a essência última das coisas, passando do "corpo" para a "consciência"

O aspecto mais significativo dessa transformação está no romance Il fu Mattia Pascal (1904), que rompeu definitivamente os laços de nosso autor com a estética verista. Mattia Pascal, depois da inebriante e efêmera liberdade, pretende voltar à sua personalidade anterior, 
mas agora lhe resta apenas ser "o falecido Mattia Pascal", máscara que a sociedade lhe prescreveu, espectro sem personalidade e sem vida, condenado a levar flores ao seu próprio túmulo.

É a partir de 1904, provavelmente, que Pirandello começa a pensar mais sistematicamente em uma poética do "Humorismo" e no binômio "vida e forma", criando o que Adriano Tilgher, filósofo e respeitado crítico militante de literatura e teatro, formulou como uma peculiar "filosofia" 10 pirandelliana, fio condutor de sua poética. Trata-se, todavia, de uma concepção simples, esquemática, mais próxima da fábula do que de uma teoria filosófica. Através da leitura das obras de Pirandello, sobretudo para o teatro, mas também das novelas, Tilgher elaborou uma teoria segundo a qual, estaria implícito na obra que o espírito humano, como todos os outros "fenômenos" da natureza, faz parte da lei da perene mutação que está em todas as coisas: uma lei segundo a qual tudo se transforma, tudo passa, tudo flui. Em outras palavras, "não se banha duas vezes a mesma mão na mesma água do mesmo rio".

A vida está no movimento, a morte, na imobilidade, e portanto, tudo o que está aprisionado em uma forma rígida é ausência de vida. Nada permanece como é hoje; nenhuma realidade é definitiva e conclusiva. No mundo não existe nada certo. Em nossa vida física e espiritual nada é absoluto e definitivo; tudo é instável e relativo. Nenhuma opinião, nenhum comportamento pode ser considerado imutável e conclusivo, tudo o que hoje é assim, amanhã não o será.

Esse forte conflito entre a força profunda da vida e as cristalizações da forma faz com que a vida acabe irremediavelmente sufocada pela forma, que é regulada pela ideologia e pelas convenções, pelas leis civis, contrariando os desígnios da própria vida que, por sua natureza, consistiria em um fluxo contínuo e incontrolável condenado a morrer ao se tentar fixá-lo em uma forma qualquer.

\footnotetext{
${ }^{10}$ TILGHER, Adriano. Studi sul teatro contemporaneo. Roma: Libreria di Scienze e Lettere, 1923.
} 
O homem participa desta lei da natureza, traz dentro si o fluxo contínuo e móvel, e, portanto, não pode ter uma personalidade única e estável, estando em constante transformação. Não tem apenas uma realidade, pois tudo é mutável e ilusório ou incerto. Assim, quem pretende ter uma personalidade definida e única, ou quer que os outros a tenham, lança-se a um trabalho absurdo e vão. Na novela "La trappola" (1912,US), Pirandello explica assim essa "filosofia":

In principio era il Caos, ma lo spirito di Dio non scorreva su di esso a ordinarlo. Il Caos era un immenso Flusso incandescente, in cui tutto ribolliva, informe e indistinto e senza tempo. Qualche parte di quello scorrente flusso si arrestò, si solidificò, assunse una forma: la quale era la trappola che a poco a poco avvolse di sé la materia ardente, la raggelò, la solidificò. Il flusso era la vita primeva dell'uomo e delle cose, la forma fu la morte: la nascita dell'uomo, della terra, degli astri fu dunque la morte della gran vita universale. Quella che noi chiamiamo vita è dunque la morte dell'originario flusso imprigionato dalla forma e dal tempo. ${ }^{11}$

Mesmo convencido de que se fixar em uma determinada "forma" significa morrer, já que toda "forma" é a cessação da vida, o homem tende fatalmente a vestir uma "forma", uma personalidade, que o caracterize. No momento exato em que ele a assume, sente que ela é a morte, que não lhe serve mais e deseja experimentar novas "formas", perpetuamente insatisfeito, infeliz e inseguro.

\footnotetext{
11 "No princípio era o Caos, mas o espírito de Deus não fluía sobre ele para ordená-lo. O Caos era um imenso Fluxo incandescente, no qual tudo fervia, informe, indistinto e sem tempo. Algumas partes deste fluxo contínuo pararam, se solidificaram, assumiram uma forma. Esta forma era a armadilha que pouco a pouco envolveu a matéria ardente, congelou-a, solidificou-a. O fluxo era a vida primitiva do homem e das coisas, a forma foi a morte: o nascimento do homem, da terra, dos astros foi, portanto, a morte da grande vida universal. O que nós chamamos vida é a morte do fluxo original aprisionado pela forma e pelo tempo". PIRANDELLO, Luigi. La trappola. In Novelle per un anno. 3 vol. Milano: Mondadori (“I Meridiani”), 2007, vol. 1, tomo 1, p. 775 .
} 
Mas não é apenas o indivíduo que tende fixar a si mesmo. Aqueles que estão a seu redor - a sociedade com seus preconceitos e convenções - também tendem a subjugá-lo a uma "forma" estática, de acordo com o modo como o vêem, baseados nas suas ações.

Na obra pirandelliana dessa segunda fase, o fato passa a determinar a "forma", são os acontecimentos que determinam e condicionam o indivíduo na "forma" que o identifica e aprisiona. É o que afirma, por exemplo, o personagem Simone Pau, em Quaderni de Serafino Gubbio operatore (1915):

Noi possiamo benissimo non ritrovarci in quello che facciamo; ma quello che facciamo è, resta fatto: fatto che ti circoscrive, ti da comunque una forma e ti imprigiona in essa. Vuoi ribellarti? Non puoi [...] Tu sei prigioniero di quello che hai fatto, della forma che quel fatto ti ha dato. ${ }^{12}$

Ou o Pai de Sei personaggi in cerca d'autore (1921):

[...] quando in qualcuno dei nostri atti, per un caso sciaguratissimo, restiamo, all'improvviso, come agganciati e sospesi, ci accorgiamo [...] di non essere in quell'atto, e che dunque un'atroce ingiustizia sarebbe giudicarci da quello solo, tenerci agganciati e sospesi, alla gogna, per una intera esistenza, come se questa fosse assommata tutta in quell' atto. ${ }^{13}$

O homem nunca conseguirá se fixar em uma "forma" que o represente, pois para ele "realidade" e "verdade" nunca coincidem, de maneira que ele nunca poderá fazer valer uma sua realidade imutável, porque não tem uma personalidade sua, única, mas está sempre

\footnotetext{
${ }^{12}$ Nós podemos muito bem não nos reconhecer naquilo que fazemos, mas o que fazemos é, permanece fato: fato que o circunscreve, que não obstante dá uma forma e o aprisiona nela. Você quer se rebelar? Não pode [...] Você é prisioneiro daquilo que fez, da forma que aquele fato lhe deu. PIRANDELLO, Luigi. Quaderni di Serafino Gubbio, operatore. In: Tutti i romanzi, 4 vol. Milano: Mondadori, vol. 2, 1949, p. 759.

${ }^{13}[. .$.$] quando em qualquer de nossos atos, por um acaso muito infeliz, ficamos de repente como que atrelados e$ suspensos, nos damos conta [...] de que não somos aquele ato, e que, portanto, seria uma atroz injustiça sermos julgados apenas por ele, sermos mantidos atrelados e suspensos, acorrentados, por toda uma existência, como se esta se resumisse toda naquele ato. PIRANDELLO, Luigi. Sei personaggi in cerca d'autore. In: Maschere nude, 4 vol. Milano: Mondadori, vol. 1, 1949, p.55.
} 
mudando, assumindo para cada um que o conhece uma "forma" diferente e não coincidente com aquilo que pensa e sente, o que torna inútil e ilusória a pretensão da sociedade em julgálo por um ou outro aspecto. Sua personalidade se desdobra e muda continuamente; ele nunca é o mesmo, mas um embrião de si mesmo, debatendo-se no escuro do mistério que envolve a vida, sem conhecimento, sem certezas ou verdades.

Essa absurda pretensão, nossa ou da sociedade, de buscar a definição em um ato ou "forma" na qual possamos nos reconhecer inteira e definitivamente, nos conduz à incomunicabilidade e à mais amarga solidão, à mais desolada incompreensão. É como se falássemos línguas diferentes, incompreensíveis, incapazes de estabelecer uma relação recíproca; como se fôssemos obrigados a permanecer imóveis enquanto a vida transcorre incontrolável, abandonando-nos às margens de um rio, como refugos.

A "forma" é a máscara, o aspecto exterior que o indivíduo assume dentro da organização social por vontade própria ou porque os outros assim o vêem e julgam. É na "forma" que o indivíduo se torna personagem.

O conceito de "forma" nas novelas e nos romances é equivalente ao conceito de "máscara" no teatro. A "forma" é determinada pelas convenções sociais, pela hipocrisia que está na base das relações humanas. É na máscara que encontramos o mais profundo contraste entre a ilusão e a realidade: a ilusão de que a realidade seja igual para todos e a realidade de que se vive sob uma "forma", da qual nunca se pode escapar. A máscara é a representação mais evidente da condenação do indivíduo a recitar sempre o mesmo papel, imposto de fora, com base nas relações sociais.

É o que acontece, por exemplo, com o personagem da novela "La carriola" (1916, C). Um dia, ao voltar para casa de trem, cansado e um tanto entediado, adormece e começa a sentir que tudo o que viveu até aquele momento lhe é estranho; tudo que construiu como 
advogado, ou o que os outros construíram em torno dele com base nas convenções sociais, não faz parte de sua essência. De repente, ele descobre que aquela não pode ser sua vida, que seu espírito não se reconhece naquele que todos respeitam e admiram.

Perché ogni cosa è una morte.

Pochissimi lo sanno; i più, quasi tutti lottano, s'affaticano per farsi, come dicono, uno stato, per raggiungere una forma; raggiuntala credono d'aver conquistato la loro vita, e cominciano invece a morire. Non lo sanno, perché non si vedono; perché non riescono a staccarsi più da quella forma moribonda che hanno raggiunta; non si conoscono per morti e credono d'essere vivi. Solo si conosce chi riesca a veder la forma che si è data o che gli altri gli hanno data, la fortuna, i casi, le condizioni in cui ciascuno è nato. Ma se possiamo vederla, questa forma, è segno che la nostra vita non è più in essa... Possiamo dunque vedere e conoscere soltanto ciò che di noi è morto. Conoscersi è morire. ${ }^{14}$

Dessas considerações sobre a luta insolúvel entre a estaticidade da forma e a constante mobilidade dos impulsos interiores, derivam muitos dos aspectos característicos da arte pirandelliana, principalmente nas obras que vão de 1904 (Il fu Mattia Pascal) até aproximadamente 1926 (Uno, nessuno e centomila), passando pelas quase duas centenas de novelas escritas no período.

De forma mais sistemática, Pirandello organizou as idéias acima descritas no ensaio L'umorismo, ${ }^{15}$ publicado em 1908 e revisto em 1920, que compõe, juntamente com o ensaio

\footnotetext{
${ }^{14}$ Porque tudo é morte. / Pouquíssimos sabem disso; os outros, quase todos lutam, esforçam-se para construir, como dizem, uma posição, para alcançar uma forma; depois de alcançá-la, acreditam ter conquistado sua vida, e, ao contrário, começam a morrer. Não entendem isso porque não se vêem; porque não conseguem mais se separar daquela forma moribunda que criaram. Não se reconhecem como mortos e acreditam estar vivos. Só vê isso quem com consegue ver a forma que deu a si próprio, ou que os outros lhe deram, a sorte, os acasos, as condições em que cada um nasceu. Mas se podemos ver essa forma, é sinal que nossa vida não está mais ali... Podemos, portanto, ver e conhecer apenas o que está morto em nós. Connhecer a si próprio é morrer. PIRANDELLO, Luigi. La carriola. In Novelle per un anno. Op. cit., vol. 3, tomo 1, p. 558.

${ }^{15}$ PIRANDELLO, Luigi. L'umorismo. Roma: Tascabili Economici Newton, 1993.
} 
Arte e scienza,${ }^{16}$ publicado em 1901, um manifesto de sua poética e declara, em certo sentido, seu rompimento definitivo com os veristas, para assumir uma identidade toda sua de literato e escritor.

As preocupações de Pirandello sobre o assunto já haviam aparecido anteriormente em um ensaio sobre Cecco Angioleri intitulado Un preteso poeta umorista del XIII secolo, publicado em 1896, e em um artigo de 1905 sobre Alberto Cantoni, Un critico fantastico, ambos também reunidos no citado volume Arte e scienza, de 1908. No primeiro ensaio Pirandello afirma que "dare una definizione dell'umorismo, la quale sia a un tempo comprensiva e comprensibile, è in sommo grado difficile". ${ }^{17}$ mas que sob o seu ponto de vista,

l'umorismo $[\ldots]$ è sempre una forma di sentimentalismo $[\ldots]$ che ride per una faccia, la faccia opposta piangendo; ride delle sue stesse lacrime, dei suoi sogni andati a vuoto o vani, dei suoi desideri sproporzionati alla possibilità del volere. $^{18}$

Essa primeira definição de humorismo é reelaborada no ensaio de 1908, tornando-se mais clara, e se traduz em chave de leitura de sua visão de mundo e da literatura que fará a partir deste momento. Não é por acaso que ele dedica a primeira edição do ensaio ao seu emblemático personagem Mattia Pascal. ${ }^{19}$

O ensaio L’umorismo tem sua gênese nas lições dadas por Pirandello no Istituto

\footnotetext{
${ }^{16}$ PIRANDELLO, Luigi. Arte e scienza. In: Saggi e Interventi. Milano: Mondadori, 2006, pp. 587-658.

17 "dar uma definição de humorismo que seja ao mesmo tempo abrangente e compreensível é extremamente difícil”. PIRANDELLO, Luigi. Un preteso poeta umorista del secolo XIII. In: Saggi, Poesie e Scritti varii. M. Lo Vecchio Musti (org.), Milano: Mondadori, 1960, p.248.

18 “o humorismo [...] é sempre uma forma de sentimentalismo [...] que ri por um rosto enquanto o rosto oposto chora; ri das suas próprias lágrimas, dos seus sonhos perdidos ou vãos, dos seus desejos desproporcionais às possibilidades da vontade." PIRANDELLO, Luigi. Un preteso poeta umorista del secolo XIII. Op. cit., p.250.

19 A dedicatória diz o seguinte: "Alla buon’anima di MATTIA PASCAL. Bibliotecario". (À boa alma de MATTIA PASCAL. Bibliotecário).
} 
Superiore di Magistero di Roma. Nele o autor traça a história do humorismo estudando suas manifestações na arte antiga e moderna. Dividido em duas partes, o ensaio apresenta na primeira a sua concepção de humorismo e faz um inventário filológico da palavra desde o latim, passando pelo italiano, o francês, o alemão e o inglês, discutindo se o humorismo seria um fenômeno literário moderno ou teria existido desde os gregos. Discute, também, apresentando casos concretos, as interpretações, nesta chave de leitura, de textos de Angiolieri, Pulci, Folengo, Berni, Boiardo, Ariosto, Tassoni, até Meli, Pascarella e Domenico Tempio, dedicando grande espaço a Rabelais, Montaigne e Cervantes. No intuito de deixar claras as bases do que pretende mostrar, Pirandello invoca argumentos da crítica romântica e da crítica clássica, baseado no ensaio Humour classico e moderno de Alberto Cantoni, para concluir que todas as partições são arbitrárias e que, apesar de o humorismo ter existido desde a antiguidade, sua melhor caracterização do humorismo é dada pela natureza dividida do homem moderno.

A segunda parte, intitulada "Essenza, caratteri e materia dell'umorismo" [Essência, características e matéria do humorismo], é mais bem estruturada contribuindo decisivamente para a compreensão de sua teoria. Nela o autor indaga as origens e a natureza do humorismo e examina a arte como um todo, para concluir que a arte "humorística" é a única verdadeira, pois é através dela que o artista pode denunciar as contradições da realidade.

A reflexão, segundo Pirandello, é o componente principal do humorismo que, através de um processo dialético de desdobramento do sentimento, traz à luz um sentimento oposto e autêntico que não deve ser confundido com a comicidade ou a dramaticidade: é o "sentimento do contrário" que se opõe à "percepção do contrário". A reflexão não é um elemento secundário, pois é através dela que podemos entender aquilo que acontece diante de nossos olhos. A reflexão é "come un demonietto che smonta il congegno d'ogni immagine, d'ogni 
fantasma messo su dal sentimento; smontarlo per veder com'è fatto; scaricarne la molla e tutto il congegno striderne, convulso". ${ }^{20}$

Ao nos depararmos com uma situação que nos parece "fora dos eixos", a primeira coisa que notamos é que algo está ou é ao contrário do que deveria ser. Surge então a "percepção do contrário" (avvertimento del contrario). Nesse momento, a reflexão deve interferir para mostrar o que está por trás daquilo que nos parecia estranho, decompondo esta percepção nos seus mínimos elementos, fazendo surgir o "sentimento do contrário" (sentimento del contrario). Para que essa reflexão possa ocorrer, é necessário um desmascaramento das impressões superficiais na busca do âmago da verdade contida em cada ação humana, sem a veleidade de descobrir os fundamentos da vida, mas com a dramática consciência que estes fundamentos continuam desconhecidos.

Para exemplificar a diferença entre o cômico e o humorístico, Pirandello usa o caso da "velha senhora" e a seguir o trecho em que Marmeladov, o personagem de Crime e Castigo, se dirige a Raskolnikov na estalagem. Note-se que estes dois exemplos não constam da versão do ensaio de 1908 , tendo sido incluídos posteriormente, na revisão publicada em $1920 ;{ }^{21}$ Em geral, o exemplo da velha senhora vem citado isoladamente, sem as análises que o acompanham. Isso faz com que o cômico seja considerado como a origem do humorismo pirandelliano, inclusive em razão das acepções mais comuns das palavras em questão. Na verdade, o exemplo mostra a decomposição efetuada pela reflexão em um movimento que leva o observador do fato externo ("percepção do contrário") à compreensão do fato

\footnotetext{
20 “como um demoniozinho que desmonta o mecanismo de cada imagem, de cada fantasia criada pelo sentimento, desmonta-a para ver como é feita, para descarregar sua mola e ver todo o mecanismo ranger convulso. PIRANDELLO, Luigi. L'umorismo. Op. cit., p. 86.

${ }^{21}$ As implicações deste fato não são objeto deste estudo, mas é importante salientar que toda a crítica, ao utilizar os exemplos, os apresenta como se já fizessem parte do ensaio em 1908. É comum encontrar referências aos acréscimos feitos por Pirandello na segunda versão, mas elas citam apenas aqueles relativos à polêmica com Benedetto Croce.
} 
("sentimento do contrário"), dentro de um deslocamento de perspectiva que não é necessariamente cômico.

Vedo una vecchia signora, coi capelli ritinti, tutti unti non si sa di quale orribile manteca, e poi tutta goffamente imbellettata e parata d'abiti giovanili. Mi metto a ridere. Avverto che quella vecchia signora è il contrario di ciò che una vecchia rispettabile signora dovrebbe essere. Posso così, a prima giunta e superficialmente, arrestarmi a questa impressione comica. Il comico è appunto un avvertimento del contrario. Ma se ora interviene in me la riflessione, e mi suggerisce che quella vecchia signora non prova forse nessun piacere a pararsi così come un pappagallo, ma che forse ne soffre e lo fa soltanto perché pietosamente s'inganna che parata così, nascondendo così le rughe e la canizie, riesca a trattenere a sé l'amore del marito molto più giovane di lei, ecco che io non posso più riderne come prima, perché appunto la riflessione, lavorando in me, mi ha fatto andar oltre a quel primo avvertimento, o piuttosto, più addentro: da quel primo avvertimento del contrario mi ha fatto passare a questo sentimento del contrario. Ed è tutta qui la differenza tra il comico e l'umoristico. ${ }^{22}$

É interessante notar que a "velha senhora" já havia aparecido na novela "Le dodici lettere" (1897, A), como personagem secundário. O que mostra que o autor, em sua primeira fase, já se preocupava, mas talvez sem teorizá-lo, em levar o leitor à reflexão através de um fato cômico. Para efeito de comparação segue o trecho da citada novela.

\footnotetext{
${ }^{22}$ Vejo uma velha senhora, com o cabelo pintado, todo besuntado sabe-se lá de qual horrível pasta, e toda deselegantemente empetecada e vestida com roupas juvenis. Começo a rir. Sinto que aquela velha senhora é o contrário do que uma velha senhora respeitável deveria ser. Posso assim, à primeira vista e superficialmente, deter-me nesta impressão cômica. O cômico é exatamente uma percepção do contrário. Mas se agora intervém em mim a reflexão, e me insinua que aquela velha senhora talvez não tenha nenhum prazer em se enfeitar assim, como um papagaio, mas que talvez sofra com isso e o faça apenas porque se engana piedosamente que enfeitada assim, escondendo dessa forma as rugas e os cabelos brancos, consiga manter o amor do marido muito mais jovem do que ela, então não posso mais rir dela como antes, porque justamente a reflexão, trabalhando em mim, me fez ir além daquela primeira percepção, ou melhor, mais fundo: daquela primeira percepção do contrário, me fez passar a este sentimento do contrário. E está toda aqui a diferença entre o cômico e o humorístico. PIRANDELLO, Luigi. L'umorismo. Op. cit., pp. 78-79.
} 
La signora Baldinotti si lusingava d'impedire i molteplici e sfacciati tradimenti del marito (che aveva otto anni meno di lei), parandosi e acconciandosi con straordinario lusso non più conveniente né all'età né al suo corpo, e di gusto assai dubbio. E confessava - Le pare, signora mia, che vestirei così e spenderei tanto per me, se non avessi il marito giovine? E non per tanto, che crede? rimango vestita e pettinata così ad aspettarlo, signora mia, fino a mezzanotte, alle due, alle tre, fino all'alba, fino all'alba tante volte!.. - E, così dicendo, la povera signora aveva le labbra e il mento convulsi e gli occhi pieni di lagrime. ${ }^{23}$

Apesar de ser o mais citado, o "exemplo da velha senhora” não é o único do ensaio. Logo a seguir nos deparamos com um exemplo que coloca em primeiro plano a situação observada de dentro e não mais de fora: Pirandello escolhe para ilustrar a diferença entre o cômico e o humorístico o trecho em que Marmeladov se dirige a Raskolnikov na estalagem:

- "Signore, signore! oh! signore, forse, come gli altri, voi stimate ridicolo tutto questo; forse vi annojo raccontandovi questi stupidi e miserabili particolari della mia vita domestica: ma per me non è ridicolo, perché io sento tutto ciò...."24

E explica Pirandello:

23 A senhora Baldinotti iludia-se de impedir as múltiplas e descaradas traições do marido (que tinha oito anos menos do que ela), enfeitando-se e arrumando-se com um luxo extraordinário não mais conveniente nem à sua idade, nem ao seu corpo, e de gosto muito duvidoso. E confessava - A senhora acha, minha senhora, que eu me vestiria assim e gastaria tanto comigo se não tivesse um marido jovem? Não é para tanto, não acha? Fico esperando-o vestida e penteada assim, minha senhora, até à meia-noite, às duas, às três, até o amanhecer, até o amanhecer muitas vezes!.. - E, dizendo isto, a pobre senhora tinha os lábios e o queixo convulsos e os olhos cheios de lágrimas. PIRANDELLO, Luigi. Le dodici lettere. In: Novelle per un anno. Op. cit., vol. 3, tomo 2, p. 1005.

24 "Senhor, senhor! Oh! Senhor, talvez como os outros o senhor ache ridículo tudo isso; talvez eu o incomode contando estes estúpidos e miseráveis particulares da minha vida doméstica: mas para mim não é ridículo, porque eu sinto tudo isso...”. PIRANDELLO, Luigi. L'umorismo. Op. cit., p. 79. 
E questo grido è appunto la protesta dolorosa ed esasperata d'un personaggio umoristico contro chi, di fronte a lui, si ferma a un primo avvertimento superficiale e non riesce a vederne altro che la comicità. ${ }^{25}$

Passando a seguir por outros exemplos - a poesia de Giuseppe Giusti, Cervantes e seu Don Quixote, Don Abbondio de I promessi sposi - Pirandello demonstra que a reflexão que transforma a "percepção" em "sentimento" não atinge apenas as situações cômicas e, portanto, o humorismo afunda suas raízes não na comicidade, mas no sofrimento. Com o humorismo nasce uma nova dimensão da vida que é dada pelo movimento que envolve a reflexão e gera o "sentimento do contrário".

O "sentimento do contrário" distingue o escritor humorista daquele irônico, satírico ou cômico pela sua atitude diante da realidade: o escritor cômico não se utiliza da reflexão, permanecendo na superfície dos fatos narrados e o riso que ele provoca pela percepção do contrário não é o riso amargo que a consciência da condição humana desencadearia. $\mathrm{O}$ escritor irônico preocupa-se apenas com a contradição verbal entre o momento cômico e o momento dramático. Por fim, o escritor satírico coloca em evidência os defeitos humanos, mostrando seus aspectos mais negativos com a intenção de indicar o caminho correto.

Com o humorismo e a reflexão Pirandello pretende entrar mais profundamente na realidade:

Non che all'umorista però piaccia la realtà! Basterebbe questo soltanto, che per poco gli piacesse, perché, esercitandosi la riflessione su questo piacere, glielo guastasse.

Questa riflessione si insinua acuta e sottile da per tutto e tutto scompone: ogni immagine del sentimento, ogni finzione ideale, ogni apparenza della

\footnotetext{
${ }^{25}$ E este grito é justamente o protesto doloroso e exasperado de um personagem humorístico contra quem, diante dele, se fixa em uma primeira percepção superficial e não consegue ver mais do que a comicidade. PIRANDELLO, Luigi. L’umorismo. Op. cit., p. 79
} 
realtà, ogni illusione.

[...] Tutti i fenomeni, o sono illusorii, o la ragione di essi ci sfugge, inesplicabile. Manca affatto alla nostra conoscenza del mondo e di noi stessi quel valore obiettivo che comunemente presumiamo di attribuirle. È una costruzione illusoria continua. ${ }^{26}$

É nessa visão da realidade que acontece o choque entre a ilusão, que constrói as coisas a seu modo, e a reflexão, que a decompõe nas suas diversas facetas:

Ora la riflessione, sì, può scoprire tanto al comico e al satirico quanto all'umorista questa costruzione illusoria. Ma il comico ne riderà solamente, contentandosi di sgonfiar questa metafora di noi stessi messa su dall'illusione spontanea; il satirico se ne sdegnerà; l'umorista, no: attraverso il ridicolo di questa scoperta vedrà il lato serio e doloroso; smonterà questa costruzione, ma non per riderne solamente; e in luogo di sdegnarsene, magari, ridendo, compatirà. ${ }^{27}$

O humorismo, portanto, distingue um aspecto que deriva da "percepção do contrário" e um aspecto que deriva do "sentimento do contrario". O primeiro é externo ao homem e facilmente visível, e por isso qualquer um é capaz de entendê-lo; o segundo é interno ao homem e não pode ser entendido senão através da reflexão.

Enquanto todos podem perceber o aspecto cômico, pois é fácil notar quando um acontecimento está fora de lugar ou um personagem se comporta de maneira contrária ao que

\footnotetext{
26“Não que o humorista, porém, aprecie a realidade! Bastaria apenas isso, por menos que a apreciasse, para que, aplicando a reflexão sobre este prazer, ele se perturbasse. / Essa reflexão insinua-se aguda e sutil por todos os lados e tudo decompõe: qualquer imagem do sentimento, qualquer ficção ideal, qualquer aparência de realidade, qualquer ilusão / [...] Todos os fenômenos, ou são ilusórios, ou sua razão nos foge, inexplicável. O que falta mesmo à nossa consciência de mundo e de nós mesmos é aquele valor objetivo que normalmente presumimos lhes atribuir. É uma construção ilusória contínua.” PIRANDELLO, Luigi. L’umorismo. Op. cit., p. 90

27 "Ora, a reflexão sim pode revelar tanto ao cômico e ao satírico quanto ao humorista essa construção ilusória. Mas o cômico somente rirá, contentando-se em esvaziar essa metáfora de nós mesmos criada pela ilusão espontânea; o satírico desdenhará dela; o humorista, não: através do ridículo dessa descoberta verá o lado sério e doloroso, desmontará essa construção, mas não apenas para rir dela; e em vez de desdenhar dela, tomara que rindo, compadeça-se". PIRANDELLO, Luigi. L'umorismo. Op. cit., p. 90
} 
todos consideram normal, o dramático-humorístico é entendido e sentido apenas por aqueles que usam a reflexão e, portanto, não pela maioria, já que esta segue regras gerais aceitas passivamente sem se comover com as necessidades individuais. Para Pirandello cada um tem seu próprio modo de pôr em ação a reflexão, pois as necessidades pessoais são absolutamente individuais.

Riassumendo: l'umorismo consiste nel sentimento del contrario, provocato dalla speciale attività della riflessione che non si cela, che non diventa, come ordinariamente nell'arte, una forma del sentimento, ma il suo contrario, pur seguendo passo passo il sentimento come l'ombra segue il corpo. L'artista ordinario bada al corpo solamente: l'umorista bada al corpo e all'ombra, com'essa ora s'allarghi ed ora s'intozzi, quasi a far le smorfie al corpo, che intanto non la calcola e non se ne cura. ${ }^{28}$

Isso faz do humorismo um processo de representação da realidade, dos acontecimentos e dos personagens. Durante a concepção e a execução da obra de arte, o escritor através da reflexão coordena os vários elementos da estrutura da obra, fugindo do caos das sensações e dos sentimentos. Não é possível esconder a reflexão, nem mascará-la ou eliminá-la da vontade e da consciência de um personagem, como acontece com o sentimento.

La riflessione, durante la concezione, come durante l'esecuzione dell'opera d'arte, non resta certamente inattiva: assiste al nascere e al crescere dell'opera, ne segue le fasi progressive e ne gode, raccosta i varii elementi, li coordina, li compara. [...] La coscienza, in somma, non è una potenza creatrice, ma lo specchio interiore in cui il pensiero si rimira; si può dire anzi ch'essa sia il pensiero che vede sè stesso, assistendo a quello che esso fa spontaneamente. ${ }^{29}$

\footnotetext{
28 "Resumindo: o humorismo consiste no sentimento do contrário, provocado pela especial atividade da reflexão que não se oculta, que não se torna, como comumente na arte, uma forma do sentimento, mas o seu contrário, mesmo seguindo passo a passo o sentimento como a sombra segue o corpo. O artista comum cuida apenas do corpo: o humorista cuida do corpo e da sombra, como ela às vezes se alonga e às vezes se alarga, quase fazendo as contrações do corpo que, entretanto, não a leva em conta e não se preocupa com ela." PIRANDELLO, Luigi. L'umorismo. Op. cit., p. 98

29 “A reflexão, durante a concepção, assim como durante a execução da obra de arte, certamente não permanece inativa: assiste o nascimento e ao crescimento da obra, segue suas fases progressivas e goza com elas, reúne os
} 
É com a reflexão que o escritor humorista evidencia as contradições da realidade:

Cominciamo da quella che l'illusione fa a ciascuno di noi, dalla costruzione cioè che ciascuno per opera dell'illusione si fa di sé stesso. Ci vediamo noi nella nostra vera e schietta realtà, quali siamo, o non piuttosto quali vorremmo essere? Per uno spontaneo artificio interiore, frutto di segrete tendenze o d'incosciente imitazione, non ci crediamo noi in buona fede diversi da quel che sostanzialmente siamo? E pensiamo, operiamo, viviamo secondo questa interpretazione fittizia e pur sincera di noi stessi. ${ }^{30}$

E qual é a verdadeira e genuína realidade? Para Pirandello ela não pode existir porque a verdadeira realidade é caracterizada pela lei da pluralidade extremamente relativa, baseada na decadência do eu e na não univocidade:

La vita è un flusso continuo che noi cerchiamo d'arrestare, di fissare in forme stabili e determinate, dentro e fuori di noi, perché noi già siamo forme fissate, forme che si muovono in mezzo ad altre immobili, e che però possono seguire il flusso della vita, fino a tanto che, irrigidendosi man mano, il movimento, già a poco a poco rallentato, non cessi. Le forme, in cui cerchiamo d'arrestare, di fissare in noi questo flusso continuo, sono i concetti, sono gli ideali a cui vorremmo serbarci coerenti, tutte le finzioni che ci creiamo, le condizioni, lo stato in cui tendiamo a stabilirci. Ma dentro di noi stessi, in ciò che noi chiamiamo anima, e che è la vita in noi, il flusso continua, indistinto, sotto gli argini, oltre i limiti che noi imponiamo, componendoci una coscienza, costruendoci una personalità. In certi momenti tempestosi, investite dal flusso, tutte quelle nostre forme fittizie crollano

vários elementos, coordena-os, compara-os. [...] A consciência, em resumo, não é uma potência criadora, mas o espelho interior no qual o pensamento se mira; pode-se dizer até que ela é o pensamento que vê a si mesmo, assistindo aquilo que ele faz espontaneamente." PIRANDELLO, Luigi. L'umorismo. Op. cit., p. 78

30 "Comecemos por aquilo que a ilusão faz a cada um de nós, isto é, pela construção que cada um faz de si mesmo por obra da ilusão. Vemo-nos em nossa verdadeira e genuína realidade, como somos ou, até mesmo, como gostaríamos de ser? Por um artifício interior espontâneo, fruto de tendências secretas ou imitação inconsciente, não acreditamos, com boa fé, diferentes daquilo que substancialmente somos? E pensamos, agimos e vivemos segundo esta interpretação fictícia e,no entanto, sincera de nós mesmos." PIRANDELLO, Luigi. L’umorismo. Op. cit., p. 90 
miseramente; e anche quello che non scorre sotto gli argini e oltre i limiti, ma che si scopre a noi distinto e che noi abbiamo con cura incanalato nei nostri affetti, nei doveri che ci siamo imposti, nelle abitudini che ci siamo tracciate in certi momenti di piena straripa e sconvolge tutto. ${ }^{31}$

Os aspectos mais evidentes da poética do humorismo aparecem na obra de nosso autor da seguinte forma:

- O riso amargo: voltado contra os homens que tentam se iludir em fixar, definir e parar a eterna mobilidade da vida, destinado a enfatizar o contraste entre as formas estáticas, convencionais, sociais, consolidadas pelas leis, pelos usos e costumes que os homens criaram, e que não está de acordo com o eterno fluir da realidade viva e atual.

- O desdobramento da consciência: se a verdade é relativa e algo que não se pode compreender, então nossa consciência também não tem um aspecto unitário, é como a "erma bifronte", com uma face que ri da outra que chora; o que deveria ser a unidade de medida, o metro para conhecer e julgar as coisas, decompõe-se e varia de uma pessoa para a outra ou, na mesma pessoa, de um momento para o outro, já que a realidade é relativa, eternamente móvel e contraditória.

- O grotesco e o paradoxo: manifestam-se quando decidimos não aceitar a

\footnotetext{
31 “A vida é um fluxo contínuo que nós procuramos parar, fixar em formas estáveis e determinadas, dentro e fora de nós, porque nós já somos formas fixadas, formas que se movem em meio a outros imóveis e que, porém, podem seguir o fluxo da vida até que, enrijecendo pouco a pouco, o movimento cada vez mais lento, não cesse. As formas nas quais procuramos parar e fixar em nós este fluxo contínuo, são os conceitos, são os ideais com os quais gostaríamos de conservar-nos coerentes, todas as ficções que criamos, as condições, o estado no qual tendemos a nos estabilizar. Mas, dentro de nós mesmos, naquilo que chamamos alma, e que é a vida em nós, o fluxo continua, indistinto, sob as barreiras, além dos limites que nos impomos, compondo-nos uma consciência, construindo-nos uma personalidade. Em certos momentos tempestuosos, sob as investidas do fluxo, todas as nossas formas fictícias desmoronam miseravelmente; e até aquilo que não escorre sob as barreiras e além dos limites, mas que nos parece distinto e que nós canalizamos com cuidado em nossos afetos, nos deveres que nos impomos, nos hábitos que nos traçamos, em certos momentos de inundação transborda e devasta tudo." PIRANDELLO, Luigi. L’umorismo. Op. cit., p. 93.
} 
máscara que a sociedade nos impõe, como faz Chiàrcaro em "La patente" (1911, R), ou nos rebelamos contra ela, como faz Vitangelo Moscarda em Uno, nessuno e centomila (1926).

- A análise introspectiva do homem: que procura conhecer e entender a eterna mobilidade para fixá-la e estabilizá-la em uma forma, de maneira a convencer a si próprio e aos outros das suas "razões".

Uma vez estabelecidas a origem e a natureza da relação vida e forma e a tarefa do escritor humorista, resta verificar como o personagem pirandelliano entra em contato com essa realidade e como reage diante dessa lei implacável que o obriga a escolher uma máscara. Isso, em geral, acontece de improviso, causado por algum acidente que muitas vezes é banal, mas chama sua atenção e o faz refletir, faz saltar a mola comprimida, faz com que entenda o jogo da vida. Então, ele vê tudo claro, entende qual é o mecanismo que regula a vida humana e explode numa reação que se confunde muitas vezes com a loucura, e que na verdade é um andar contra a corrente, um choque contra o mundo que o chama de louco apenas por não aceitar suas leis, pois, depois que se entendeu o jogo, é preciso aprender a jogar para conseguir a liberdade. É o caso, por exemplo, do personagem Belluca, da novela "Il treno ha fischiato" (1914, US), que ao ouvir o apito do trem, refugia-se em um mundo ideal, distante dos seus sofrimentos quotidianos, semeado de montanhas nevadas, horizontes azuis e densas florestas que, momentaneamente, tentam deter o fluxo da vida.

As reações dos personagens, no entanto, podem ocorrer de várias formas, dependendo de seus temperamentos e da situação em que eles entendem o jogo da vida. Pode haver uma reação passiva e resignada, uma espécie de resistência passiva, em que eles aceitam a máscara que os outros lhes dão, convivem com ela, impondo-se leis mesmo sabendo que elas são 
mutáveis, agarram-se àquela máscara na esperança, ilusória, de que ela possa refletir algo de seu, para ter um pouco de paz consigo mesmos e com os outros. Mas aos poucos a máscara se revela inadequada e então eles cedem, deixam-se levar e aceitam tudo com resignação abandonando-se à "pena de viver". Como no caso do professor de história das religiões Bernardino Lamis, da novela "L'eresia catara" (1905, M), que vive uma vida miserável sustentando a cunhada com vários filhos e cuja única alegria é ter escrito um livro sobre a heresia cátara ${ }^{32}$ ignorado pela crítica, e que havia sido, três anos depois, praticamente copiado por um autor alemão. O professor Lamis prepara uma aula em que fará um ataque ao autor alemão e à crítica que o havia elogiado, mas no dia da aula seus dois únicos alunos faltam por causa do mau tempo e o professor, enlevado na sua lição, não nota que dá aula para os casacos da turma da sala ao lado postos para secar.

A posição passiva e resignada é transitória e logo assume um aspecto irônicohumorístico. É a reação do personagem que não aceita passivamente os fatos da vida, mas contrariado, aceita a máscara que os outros lhe dão, ou que ele mesmo se dá, assumindo um comportamento polêmico, frio e obstinado, que vai contra todas as leis sociais tradicionais e constituídas, zombando do destino que o colocou nessa situação, rindo de si mesmo e ostentando um desprezo pela vida que irá desaguar numa exasperada revolta moral. O personagem olha para sua imagem refletida no espelho, se descobre ridículo e a evita.

O homem, segundo Pirandello, não tem culpa dessa sua condição, uma vez que está dividido entre uma força moral que o impele para o bem e uma força instintiva que o impele para o mal:

Ecco un alto funzionario che si crede, ed è, poveretto, in verità, un galantuomo! Domina in lui 1'anima morale. Ma un bel giorno l'anima

\footnotetext{
${ }^{32}$ Importante dissidência da Igreja Católica na Europa, entre os séculos XI e XV.
} 
istintiva, che è come la bestia originaria acquattata in fondo a ciascuno di noi, spara un calcio all'anima morale e quel galantuomo ruba. ${ }^{33}$

Nesses casos, o humorismo pirandelliano torna-se tristeza e amarga lamentação, uma vez que as ilusões humanas nascem de um sentimento espontâneo e ingênuo, mas quando o homem aceita conscientemente a máscara, mostrando-se diferente do que realmente é, mentindo continuamente para si mesmo e para os outros, comete um engano. Este engano Pirandello denuncia cruamente, sem piedade, transformando as ilusões em um humorismo cínico e quase maligno. Os comportamentos insinceros, as tortuosidades da consciência, as hipocrisias, ou seja, as máscaras às quais os homens se habituam, devem ser denunciadas para abrir os olhos daqueles que as aceitam, e aceitando-as acreditam ter alcançado a felicidade, quando, na verdade, perpetuam equívocos e agravam irremediavelmente os males sociais. Expressões típicas dessa reação irônico-humorística contra a sociedade e suas leis, são a novela "La patente" (1911, R), em que Rosario Chiàrcaro, tendo fama de trazer má sorte, dirige-se ao juiz D’Andrea para que lhe dê um Alvará de mau-olhado (iettatore) para que ele possa tirar proveito disso. O mesmo se dá na peça Il berretto a sonagli (1917), derivada das novelas "La verità" (1912, US) e "Certi obblighi” (1912, NC), em que o protagonista Ciampa, diante da possibilidade de que a esposa de seu patrão denuncie o envolvimento deste com a própria esposa, argumenta sobre as perdas sociais que podem ocorrer e a faz se passar por louca.

A terceira forma de reação é a dramática, que nasce quando o homem desesperado por não conseguir se adaptar à máscara, nem zombar humoristicamente da vida e de seus contrastes, ou ainda lidar com a imagem que lhe impuseram e aquilo que realmente sente,

\footnotetext{
${ }^{33}$ Eis um alto funcionário que acredita ser, e na verdade é, coitado, um cavalheiro! Predomina nele a alma moral. Mas um belo dia a alma instintiva, que é como a besta original escondida no fundo de todos nós, dá um chute na alma moral e aquele cavalheiro rouba. PIRANDELLO, Luigi. L'umorismo. Op. cit., p. 93
} 
arranca a máscara da representação, a máscara que agora está realmente "nua", vazia, e se mostra em toda sua humanidade desiludida, dolorosa e humilhada. Do riso humorístico passa ao pranto, da comédia ao drama, e se sente incomunicável, ofendido e infeliz. A situação parece insolúvel e a única saída é a morte ou a loucura, ou ambos, e ele permanece suspenso entre a realidade e a ilusão. A morte que anteriormente acontecia por um acidente fortuito, não predeterminado, agora é desejada e aceita como uma solução irreversível. É a trágica anulação da personalidade do homem entregue às forças que ele não consegue dominar, marionete sem vontade à mercê de um destino desconhecido e tirânico. A reação dramática talvez seja a que mais se identifica com o teatro pirandelliano, pois está presente em duas de suas obras mais importantes: Sei personaggi in cerca d'autore (1921) e Enrico IV (1923), mas as novelas também apresentam muitos personagens que decidem arrancar a máscara, como a protagonista de "La veste lunga" (1913, US), Didì Brilla, que se suicida durante uma viagem de trem em que vai ser apresentada ao noivo escolhido pelo pai ou a protagonista de “"Leonora, addio"” $(1910, \mathrm{~V})$ que também se suicida diante dos filhos por não suportar mais a máscara imposta pelo marido.

\subsection{A realidade "outra"}

É possível fixar entre 1928-29 o início de um terceiro momento na obra de Pirandello, que poderia ser chamado de "suspensão da realidade" ou dos "mitos". Depois de ter tomado contato com o mundo, o mundo de início de século que o cercava e oprimia, e constatada a "pena di vivere", Pirandello havia reagido à desilusão com a ironia humorística e o desprezo dramático, mas de acordo com ele, a ilusão é, talvez, a mais necessária das virtudes humanas 
e, por isso, o homem sempre procurará uma "forma", um modus vivendi, para poder se relacionar com os outros e enganar a si mesmo na vã esperança de encontrar algum prazer em viver. As tentativas de evitar a pena de viver, de encontrar um lugar na sociedade e uma forma que reflita sua verdade interior, são aspirações humanas pelas quais vale a pena lutar. Se a realidade não fornece esta ilusão, se a constatação a que se chega é que o homem está fragmentado, não se reconhece diante do espelho e não encontra uma saída para seu sofrimento, é hora de tentar encontrar uma realidade alternativa, na qual o espírito, não regulado pelo fluxo da vida, consiga encontrar um sentido, uma unidade. É o momento da suspenção da realidade, da poética do silêncio e do retorno aos "mitos", mesmo com a consciência de que se trata de ilusões passageiras, sensações fugazes que, no entanto, podem nos ajudar na construção de uma unidade espiritual. A esta fase pertencem as últimas novelas e as peças "míticas" La nuova colonia (1928), Lazzaro (1929), I giganti della montagna (1935-36).

As incertezas e desilusões ainda são muitas, a vida social e política parecem reprimir qualquer tentativa de entendimento entre os homens, tornando a máscara desejável e a "forma", apesar de significar morte, um instrumento de sobrevivência. Os mitos e o sentimento místico, então, teriam a capacidade de buscar no íntimo humano aquele sentimento cada vez mais reprimido e, assim, reconstituir emoções verdadeiras e duradouras pela aproximação com a natureza ${ }^{34}$ através da fé (Lazzaro), da família (La nuova colonia) e da arte (I giganti della montagna).

\footnotetext{
${ }^{34}$ É importante lembrar que a natureza, principalmente neste período, aparece com frequiência na obra de Pirandello, ora de maneira explícita, ora veladamente, e é considerada geralmente benévola e materna, como no primeiro Leopardi ou em Giovanni Pascoli. Ver, por exemplo, o último romance do autor, que já preanunciava esta terceira fase, Uno, nessuno e centomila (1926) em que o protagonista, Vitangelo Moscarda, encontra como saída a imersão na natureza.
} 
A vida, destruída pela impossibilidade de se construir uma identidade, renova-se na natureza, fazendo ressurgir a fantasia, as ilusões, os instintos e os mitos contra as forças negativas e destruidoras. Isto não quer dizer que o antigo Pirandello esteja completamente esquecido, ou que os temas anteriores tenham desaparecido completamente. Eles ainda resistem e estão sempre urgentes e vivos, não são mais predominantes, mas convivem nesta nova fase apenas iniciada. Assim como as fases não são estanques, os temas se entrelaçam e amparam de maneira a permitir uma passagem articulada entre elas. Além das obras para teatro já citadas, podemos reconhecer a nova fase principalmente nas novelas escritas entre 1930 e 1936, ou nas páginas idílico-humorísticas do inacabado romance-testamento Informazioni sul mio involontario soggiorno sulla terra.

Praticamente toda a obra pirandelliana é marcada por esse desejo de encontrar uma solução para a miséria que condena o homem. Seus personagens experimentam todas as situações e armadilhas que a vida é capaz de preparar e se debatem dentro delas procurando uma maneira de sair, tentam dar ordem e razão à vida, mas só encontram mais desgosto e desilusão.

O homem tende naturalmente a uma solução, tende a dar forma ao Caos, harmonia à desordem, mesmo se depois a "forma" trouxer a morte, mesmo se a tentativa está destinada a falir. Esta solução não está na loucura ou na fuga, como o próprio Pirandello constatou, não está na morte, mas além desta, está naquilo que é essencial ao ser humano, naquilo que ele traz dentro de si e que lhe é mais caro e íntimo, na consciência que rejeita a máscara e se expande procurando atingir outras consciências mais verdadeiras que não necessitam da ilusão para serem completas. Está na arte que é capaz de atingir o "sentimento do contrário" sem rir ou se compadecer, na arte muitas vezes esquecida e até considerada morta pela humanidade, mas que sobrevive nos mitos e na natureza, indo além da vida e superação dos 
limites humanos conhecidos.

A morte do autor não permitiu que esta investigação fosse completada, a solução apenas vislumbrada não pôde ser concluída. Mesmo assim, apesar das poucas obras que compõem esta última fase (21 novelas e 3 peças teatrais, sendo uma incompleta), e algumas ainda se ressentindo das influências da fase anterior, parece que Pirandello tinha encontrado a saída. Prova disso talvez seja a frase do mago Cotrone, de I giganti della montagna, explicando à Condessa como se vive em La Scalogna:

Non bisogna più ragionare. Qua si vive di questo. Privi di tutto, ma con tutto il tempo per noi: ricchezza indecifrabile, ebollizione di chimere. Le cose che ci stanno attorno parlano e hanno senso soltanto nell'arbitrario in cui per disperazione ci viene di cangiarle. Disperazione a modo nostro, badiamo! Siamo piuttosto placidi e pigri; seduti, concepiamo enormità, come potrei dire? mitologiche; naturalissime, dato il genere della nostra esistenza. Non si può campare di niente; e allora è una continua sborniatura celeste. Respiriamo aria favolosa. Gli angeli possono come niente calare in mezzo a noi; e tutte le cose che ci nascono dentro sono per noi stessi uno stupore. ${ }^{35}$

\footnotetext{
${ }^{35}$ Não é preciso mais pensar. Aqui se vive disto. Privados de tudo, mas com todo o tempo para nós: riqueza indecifrável, ebolição de quimeras. As coisas que estão ao nosso redor falam e apenas têm sentido no arbitrário em que, por desespero, resolvemos alterar. Desespero à nossa maneira, claro! Somos um tanto pacíficos e preguiçosos; sentados, imaginamos enormidades, como posso dizer? mitológicas; muito naturais, dada a natureza de nossa existência. Não se pode viver de nada; e então é uma contínua embriaguez celeste. Respiramos ar fabuloso. Os anjos podem, sem mais nem menos, descer no meio de nós; e todas as coisas que nascem dentro de nós são um espanto para nós mesmos. PIRANDELLO, Luigi. I giganti della montagna. In: Maschere nude, 4 vol. Op. cit., vol. 2, 1952, p. 631.
} 


\section{Pirandello "novellaro".}

A carreira literária de Pirandello inclui vários gêneros, desde a poesia escrita, principalmente na juventude, até o teatro que o popularizou. Mas é na novela, gênero que nunca deixou de cultivar, que o universo pirandelliano encontra sua máxima realização. Ainda que em tempos e ritmos diferentes, as novelas configuram-se como o grande laboratório em que nosso autor refletiu sobre a difícil aventura do homem de seu tempo, dando vida a personagens que seriam seus legítimos representantes.

Desde a adolescência, o jovem Luigi demonstra predisposição para a literatura, escrevendo peças teatrais para serem representadas em casa, pelos irmãos, sob sua direção. Em 1884, então com 17 anos, publica no jornal "La Gazzetta del Popolo della Domenica" uma novela, "Capannetta - Bozzetto Siciliano" (1884, A), que recebe forte influência das idéias e da obra de seu conterrâneo Giovanni Verga.

Depois de completar os estudos secundários, inscreve-se, por influência do pai, na Faculdade de Direito de Palermo, mas cursa ao mesmo tempo a Faculdade de Letras. Decidindo-se definitivamente pelo curso de letras, deixa Palermo em 1887, para completar o curso na Università degli Studi di Roma La Sapienza. Devido a uma discussão com o professor de latim, Onorato Occioni, reitor da faculdade, transfere-se, por recomendação do professor de Filologia Romana, Ernesto Monaci, para a Universidade de Bonn, onde se 
formará em 1891 com uma tese, em alemão, sobre o dialeto de Girgenti. ${ }^{36}$ Durante este período, publica seus primeiros escritos: dois livros de poesia - Mal giocondo e Pasqua di Gea - e uma tradução das Elegias Romanas, de Goethe.

Retornando à Itália, depois de uma breve estada em Agrigento, transfere-se definitivamente para Roma, financiado pelo pai, para se dedicar à vida literária e à carreira de escritor, abandonando definitivamente as pretensões acadêmicas e a filologia, que "guasta lo stomaco e rimpicciolisce il cervello". 37

Em Roma, conhece o messinês Ugo Fleres, poeta, jornalista e crítico, que o introduz no ambiente literário da capital apresentando-o a vários outros conterrâneos radicados em Roma e ligados à escola verista, como Giuseppe Màntica, Giovanni Alfredo Cesario, Giuseppe Aurelio Costanzo, Nino Martoglio, Ugo Ojetti e Luigi Capuana. Em 13 de novembro de 1892, publica, na revista "Tavola Rotonda", a novela "La ricca" (1892, A), e no mesmo ano começa a escrever seu primeiro romance, Marta Ajala, publicado em 1901 com o título L'esclusa.

O ano de 1894 pode ser considerado como inaugural na novelística pirandelliana, com a publicação de seu primeiro livro de narrativa, o já citado livro de novelas Amori senza amore, uma vez que as duas novelas publicadas anteriormente ainda não caracterizam uma produção constante. Assim, é a partir deste ano, em que publicou sete novelas, e o livro que recolhia três delas, que nosso autor passa a escrever mais regularmente a narrativa curta.

Suas novelas são publicadas principalmente nas revistas "Nuova Antologia" e "Marzocco", nas quais o escritor colaborava também com artigos, ensaios e crítica de teatro. A partir daí, as novelas acompanharão toda a carreira do escritor, se bem que nos primeiros

\footnotetext{
${ }^{36}$ Laute und Lautentwickelung derMundart von Girgenti (Fonética e desenvolvimento fônico do dialeto de Girgenti)

37 "arruína o estômago e encolhe o cérebro". Carta à irmã Lina, datada de 13 de janeiro de 1891. Cfr. GIOVANARDI, Daniela. I lettori d'italiano in Germania. Tübingen: Gunter Narr Verlag, 1996, p. 46.
} 
tempos pareça que ele as escrevia de forma diletante, ou seja, não pretendia fazê-lo profissionalmente, pois ainda considerava a poesia, e talvez o teatro, como sua verdadeira forma de expressão. Prova disso é que nos primeiros anos de produção não solicitava dos editores das revistas uma remuneração pelas novelas, bastando-lhe que fossem publicadas.

Ao escrever suas novelas, o autor percorria o caminho da tradição narrativa italiana que surgira no século XIV com o Novellino e que alcançara sua forma definitiva com Boccaccio em seu Decameron. A novela é uma forma narrativa breve que se concentra em um acontecimento, extremamente relevante, o ponto culminante da vida de um personagem. Muitas vezes têm-se a impressão de que esse acontecimento é mais importante do que o próprio personagem, mas na verdade, ele serve como veículo para pôr à prova as certezas do protagonista, testando suas forças e fraquezas, suas reações diante de uma situação limite, impulsionando-o a buscar a compreensão do que muitas vezes é ininteligível, transformandoo em paradigma da condição humana.

Toda a novelística, como a obra de Pirandello em geral, é baseada no personagem vivendo uma situação limite; o momento em que, muitas vezes em meio a um acontecimento banal e sem importância, experimenta uma espécie de revelação, uma epifania, e começa a "entender o jogo". É o instante em que a máscara cai, ou é arrancada, e ele se vê diante de si mesmo, como no olho de um furacão com todas as forças da vida agindo à sua volta.

Nas novelas, e mais tarde no teatro, os personagens do universo pirandelliano são o veículo através do qual o autor representa as angústias de sua própria vida e de seu tempo. São uma quase multidão que se agita e debate, entra e sai de cena, às vezes ostensivamente, às vezes nas pontas dos pés, para representar em voz alta a comédia delirante e absurda da vida. São notáveis as novelas em que o escritor dá voz ao personagem enquanto tal: "Personaggi" (1906, A), "La tragedia di un personaggio" (1911, US) e "Colloqui coi personaggi" (1915, A), 
bem como seu drama mais famoso Sei personaggi in cerca d'autore (1921). Segundo Debenedetti: “A psicologia nunca atinge os personagens, não coincide nunca com eles: não chega a ser sua motivação, porque é a sua punição." 38

Já estabelecido em Roma, participando da vida intelectual da maior cidade italiana e casado com Maria Antonietta Portolano desde 1894, Pirandello dedica-se cada vez mais à narrativa, mas ainda sem deixar de lado a poesia. O nascimento dos filhos e as constantes dificuldades financeiras do pai, que provia o sustento de toda a família, praticamente obrigam Pirandello a aceitar, em 1897, o cargo de professor de Lingüística e Estilística no "Istituto Superiore di Magistero di Roma", que ocupará por mais de vinte anos.

As aspirações literárias, no entanto, não são esquecidas e, em 1898, juntamente com Carlo Falbo e Ugo Fleres, funda a revista semanal "Ariel" que terá 25 edições. Sobre o grupo fundador da revista e sua posição artística, que incluía Luigi Capuana e outros sicilianos, diz Romano Luperini:

De fato, tratou-se de um núcleo de resistência que, ao mesmo tempo em que constatava a crise do positivismo e do naturalismo e gradualmente afastavase destas posições, também não pretendia aderir a novas, fossem elas o simbolismo, o irracionalismo decadente ou, mais tarde, as dos jovens grupos florentinos ou do nascente neo-idealismo representado por Benedetto Croce. $^{39}$

As novelas e os romances sucedem-se de forma irregular, uma vez que as obrigações de professor e colaborador de revistas literárias consomem boa parte do tempo necessário para a escrita de ficção, e ainda é forte a inclinação para a poesia.

\footnotetext{
${ }^{38}$ DEBENEDETTI, Giacomo. Italiani del Novecento. Firenze: Giunti, 1995, p.141

${ }^{39}$ LUPERINI, Romano. Pirandello. Roma-Bari: Editori Laterza, 2005, pp. 11-12.
} 
O ano de 1903 é, sob muitos aspectos, difícil para a família Pirandello. O dote de Antonietta, que fora aplicado em uma mina de enxofre e sustentava a maior parte das despesas da família, é totalmente perdido quando a mina se alaga. Antonietta, que já não tinha uma saúde mental muito estável desde a juventude, abalada pelo choque, sofre uma paralisia nas pernas que a manterá presa ao leito por seis meses. A doença evolui até atingir uma grave forma de paranóia com manifestações perigosas para si e para os outros - a doença a deixará incapaz, sob cuidados médicos pelo resto da vida.

O desequilíbrio econômico obriga Pirandello, depois de pensar em suicídio, a definir em outras bases a sua relação com a literatura que, se antes era desinteressada, agora deve se tornar fonte de renda para o sustento da família, visto que o magro salário de professor não podia certamente bastar para suas necessidades. Além disso, passa a dar lições particulares de alemão, graças à sua competência no idioma. Em uma carta, do início de 1904, endereçada ao amigo Angiolo Orvieto, que havia sido diretor da "Marzocco", ele resume bem a nova situação:

Avevo la novellina, intitolata La buon'anima, e invece che al "Marzocco", l'ho mandata alla "Riviera ligure". E sai perché? è triste, molto triste, questo perché; ma, anche a costo d'affliggerti, sarà meglio che te lo dica, per togliere ogni ombra fra noi. [...] Sappi che da circa un anno le condizioni finanziarie della mia famiglia, per una improvvisa sciagura, non sono più quelle di prima. Una grande zolfara, che dava a mio padre e a tutti noi l'agiatezza, s'è allagata, e l'allagamento ha prodotto danni per più di quattrocento mila lire. La sciagura non è del tutto irrimediabile. Mio padre ha già speso in un anno circa duecento mila lire per la costruzione d'un acquedotto e d'un piano inclinato. Ora la zolfara comincia a votarsi ma ci vorrà per lo meno un altr'anno, prima che si riprenda l'estrazione del minerale. Intanto io son rimasto... con tre figliuoli e la moglie... immagina tu in quale stato! Il misero stipendio di professore straordinario all'Istituto 
Superiore mi basta appena per pagar la pigione di casa. Bisogna che m'ajuti con le mani e coi piedi, per guadagnare, scrivendo. È una terribile prova, amico mio! inattesa! [...] Tu sai che da parecchi anni presto al "Marzocco" gratuitamente la mia collaborazione. Figurati con che cuore vorrei seguitare a mandar di tanto in tanto qualche novella. Ma... te l'ho detto, ne avevo una e per venticinque lire l'ho mandata a un altro giornale! $!^{40}$

Ainda para Angiolo Orvieto, ele explica sua resignação em escrever narrativas curtas em detrimento da poesia:

[...] da quando mi son messo a scriver novelle, son diventato di professione "novellaro" (come direbbero a Roma) e nessuno pensa più che cominciai da poeta e se per poco mi rivolgo a un editore per avere stampato un libro di versi, mi sento rispondere: "Se per un libro di novelle, sì; versi, no: i versi non vanno!". 41

A vocação, ou melhor, o gosto pela poesia, porém, nunca seria completamente esquecido. Um de seus últimos trabalhos para o teatro, La favola del figlio cambiato (1934), é escrito em versos.

\footnotetext{
40 "Eu tinha a novelinha intitulada La buon'anima, e em vez de enviá-la à "Marzocco", mandei para a "Riviera ligure". E você sabe porque? É triste, muito triste, esse porquê; mas, mesmo a custo de afligi-lo, é melhor que eu diga, para acabar com qualquer sombra entre nós. [...] Saiba que há cerca de um ano, as condições financeiras de minha família, por uma calamidade imprevista, não são mais como antes. Uma grande mina de enxofre, que dava a meu pai e a todos nós comodidade, alagou-se, e o alagamento produziu danos de mais de quatrocentas mil liras. A calamidade não é completamente irremediável. Meu pai já gastou cerca de duzentas mil liras para a construção de uma barragem/declive e um aqueduto. Agora a mina começa a esvaziar, mas ainda demorará mais um ano para que se reinicie a extração do mineral. No entanto, eu fiquei... com três filhos e esposa... imagine você em que estado! O mísero salário de professor extraordinário no Istituto Superiore basta apenas para pagar o aluguel da casa. É preciso que eu ajude escrevendo com "mãos e pés" para sobreviver. É uma provação terrível, meu amigo! Inesperada! [...] Você sabe que há muitos anos presto gratuitamente minha colaboração à "Marzocco". Você não imagina como eu gostaria de, de vez em quando,enviar uma novela. Mas... como disse, tinha uma e por vinte e cinco liras mandei para outro jornal!" ARMELliNI, G.; COLOMBO, A. La letteratura italiana: Primo Novecento, vol. 7. Bologna: Zanichelli, 1999, p. 318.

41 “'...] desde que comecei a escrever novelas, tornei-me 'novellaro' (como diriam em Roma) de profissão, e ninguém lembra mais que comecei como poeta. E se de vez em quando me dirijo a um editor para que ele publique um livro de versos, ele me responde: 'Se for um livro de novelas, sim; versos, não: os versos não agradam!'. PUPO, Ivan. Interviste a Pirandello: "Parole da dire, uomo, agli altri uomini”. Soveria Mannelli, Rubbettino Editore, 2002, p. 107.
} 
O fato é que, em termos de narrativa, Pirandello já havia publicado, até este momento, 67 novelas em jornais e revistas, sendo algumas recolhidas nos volumes Amori senza amore (1894), Beffe della vita e della morte (1902) e Quand'ero matto... (1902), além de 2 romances - L'esclusa e Il turno -, e estava preparando seu romance mais conhecido, Il fu Mattia Pascal, cuja primeira versão iria ser publicada em capítulos, a partir de abril de 1904, na revista "Nuova Antologia". Apesar de contar com uma produção narrativa bastante razoável, parece que o autor ainda a considerava apenas como uma "experiência" (como havia sugerido Capuana) pela qual não receberia remuneração e que não se configuraria como profissão. Mas as necessidades financeiras e a possibilidade de comercializar suas narrativas breves certamente foram decisivas para modificar essa opinião e levá-lo a assumir a narrativa profissionalmente.

Em realidade, as tentativas de escrever para o teatro haviam sido constantes desde a juventude, mas até aquele momento ele não conseguira encenar nenhuma das peças que escrevera. A poesia havia dado alguns frutos, porém não tivera sucesso de crítica, nem de público. A crítica e o ensaísmo, publicados nas revistas especializadas, também não tiveram grande repercussão. Por outro lado, a narrativa curta, se não havia feito grande sucesso até aquele momento, também não decepcionara, sendo bem recebida e poderia garantir uma renda adicional. De fato, ao saber das necessidades financeiras do autor, a direção da revista "Marzocco" enviou a Pirandello a quantia de 100 liras, como retribuição pelas novelas já publicadas.

Pirandello estava então com 37 anos e tinha mulher e filhos para sustentar. As novelas, além de tudo, ofereciam um vasto campo para suas indagações, para o desenvolvimento de personagens e para a busca de uma explicação e uma saída para a "pena di vivere". Se analisarmos bem, as dificuldades financeiras e o conseqüente agravamento da 
doença da esposa, não apenas direcionaram o autor para a narrativa, mas também encerraram sua primeira fase - o contato com o mundo - e o levaram a procurar uma explicação.

Seria extremamente redutivo afirmar que a maior ou menor produção novelística de Pirandello tivesse motivos exclusivamente econômicos; mas, ao mesmo tempo, é fato que a narrativa breve, pelo menos nas duas primeiras décadas do século XX, constituía um gênero largamente comercializável. Publicada nas terceiras páginas dos jornais e em um grande número de revistas e periódicos, ${ }^{42}$ a novela garantia um rendimento muito superior ao que Pirandello poderia obter com outros gêneros literários ou com a carreira de professor extraordinário. Sem dúvida, as dificuldades econômicas que Pirandello teve de enfrentar, levaram-no a optar pela novela e determinaram quantitativamente sua produção. Basta observar o gráfico abaixo, ${ }^{43}$ que ilustra o número de novelas publicadas por ano, e a curva de tendência da média das publicações anuais, para se verificar que o volume das publicações reflete, em termos gerais, as necessidades econômicas do autor. Ele se acentua a partir do nascimento dos filhos, Stefano (1895), Lietta (1897) e Fausto (1899), e aumenta decididamente após 1903, data do alagamento da mina de enxofre, começando a decair após sua estréia como dramaturgo (1910-11), diminuindo até chegar a zero na época de sua maior atividade teatral, para crescer novamente ao final da vida do autor, quando Pirandello havia decidido completar seu projeto Novelle per un anno (ver capítulo 4).

\footnotetext{
${ }^{42}$ Muitas vezes Pirandello publicava a mesma novela em um jornal e em uma ou duas revistas.

${ }^{43}$ Ver gráfico ampliado, e com mais relações com a carreira de Pirandello, no anexo 1.
} 
NOVELAS PUBLICADAS $\times$ ANO

Curva de tendência

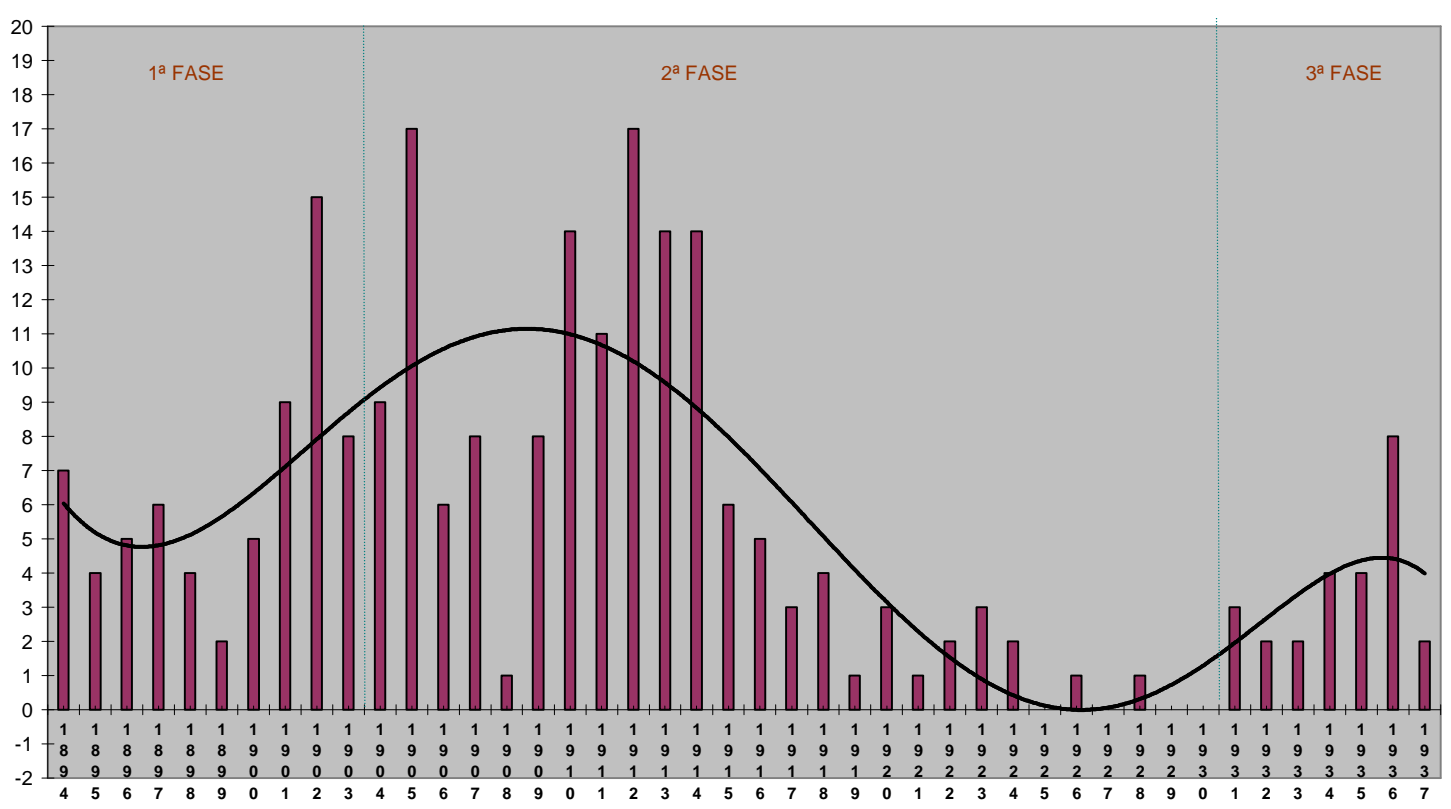

Mas Pirandello dá à novela uma atenção que vai além desta limitadora perspectiva econômica, pensando-a inclusive em termos teóricos, dando-lhe um estatuto e possibilidades cognitivas, preocupando-se com sua excessiva comercialização, com a produção artificial e repetitiva enquanto mercadoria literária largamente homologada pelo gosto corrente. ${ }^{44}$ No plano da reflexão teórica, Pirandello examina em vários escritos o problema da relação entre romance e novela. Em 1908, por exemplo, no ensaio Soggettivismo e oggettivismo nell'arte narrativa, ele nega qualquer distinção quantitativa, exterior e rigidamente formal entre os dois gêneros. Para o autor, a novela é

più che uno speciale componimento d'arte narrativa, è una maniera d'arte, senz'alcuna determinazione di lunghezza o brevità, indipendente insomma dall'estensione o dalla complessità maggiore o minore della favola. ${ }^{45}$

\footnotetext{
${ }^{44} \mathrm{O}$ que também era, aliás, uma preocupação do amigo e escritor Federigo Tozzi, ao discorrer sobre o gênero.

45 "mais do que um tipo especial de arte narrativa, é uma expressão de arte, sem qualquer determinação de extensão ou brevidade, independente, em resumo, da extensão ou da complexidade maior ou menor do
} 
Pirandello considera a novela um gênero autônomo, cuja especificidade é ter um caráter cognitivo e representativo alheio ao universo do romance. A brevidade da novela permite examinar, em fragmentos isolados, a realidade física e psíquica e, recortando os fatos, exprime numa condensação dos acontecimentos uma experiência desesperada, alucinada, que cristaliza o momento elevando-o à condição de paradigma. Segundo o autor, parafraseando e completando o pensamento de Niccolò Tommaseo, a novela é um gênero muito mais próximo da tragédia clássica do que do romance:

La novella e la tragedia classica condensano in piccolo spazio i fatti, i sentimenti che la natura presenta dilatati o dispersi. L'una e l'altra pigliano il fatto, a dir così, per la coda; e di questa estremità si contentano; intese a dipingerci non le origini, non i gradi delle passioni, non le relazioni di quella con i molti oggetti che circondano l'uomo e servono a sospingerla, a ripercuoterla, ad informarla in mille modi diversi, ma solo gli ultimi passi, l'eccesso insomma. ${ }^{46}$

Pirandello entende que a intensidade, implícita tanto na tragédia quanto na novela, é a única maneira de investigar conflitos e transmitir idealmente aquilo que não é passível de explicação. Para tanto, é preciso não se preocupar com nuances e gradações, pois apenas através de uma forma não mediada, mas direta, focalizada no particular, no momento, no gesto isolado e conclusivo, é possível se desfazer de qualquer aura de sacralidade e abandonar nossa natural predisposição à generalização para extrair significados universais de ações

enredo." PIRANDELLO, Luigi. Soggettivismo e oggettivismo nell'arte narrativa. In: Saggi, poesie, scritti varii. M. Lo Vecchio Musti (org.). Milano: Mondadori, 1960, p. 186-87.

${ }^{46}$ A novela e a tragédia clássica condensam, em um pequeno espaço, os fatos, os sentimentos que a natureza apresenta dilatados ou dispersos. Uma e outra pegam o fato, por assim dizer, pelo rabo; e se contentam com esta extremidade, interessadas em retratar, não as origens, não o grau das paixões, não sua relação com os muitos objetos que circundam o homem e servem para levá-lo adiante, reproduzi-lo, moldá-lo de mil maneiras diferentes, mas somente os últimos passos, em resumo, o excesso. PIRANDELLO, Luigi, Soggettivismo e oggettivismo nell'arte narrativa. In: Saggi, poesie, scritti varii. Op. cit., p. 205. 
particulares. A representação do "excesso", do gesto último e desesperado, desencadeado por um momento revelador de todo um sistema de valores, de um conflito entre o bem e o mal que transcende o homem, coloca em jogo os anseios mais profundos do inconsciente. Entretanto, este ainda é um procedimento moral, pois trata-se de um gesto autêntico e libertador, não determinado pela hipocrisia das convenções. A novela, portanto, é o instrumento da crise, e Pirandello a utiliza para refletir sobre as grandes modificações que estavam ocorrendo naquele momento de transição e de redefinição do papel do intelectual.

Pelo exposto acima, nota-se o empenho de Pirandello em definir exatamente a delimitação do gênero novela. É importante notar ser ele o último escritor a identificar seus escritos breves como "novela", pois já era corrente na época o termo "conto" para designar a narrativa curta. No prefácio às Novelle per un anno, Giovanni Macchia afirma:

Devido à importância que sempre atribuiu à sua necessidade de narrar, era previsível que Pirandello quisesse dar a essa forma expressiva, constituída de narrativas às vezes breves, às vezes longas e cansativas, uma denominação nobre: não conto, não fábula, mas justamente novela. ${ }^{47}$

Os termos novela e conto, principalmente em italiano, muitas vezes se confundem tendo sido usados indiscriminadamente até o final do século XIX para nomear este gênero de narrativa. Em português, entende-se como novela uma narrativa de tamanho intermediário entre o romance e o conto, porém com características temáticas mais próximas às do romance. As diferenças, no entanto, são mais sutis e difíceis de detectar.

O termo "conto", no sentido utilizado hoje em dia, afirma-se no início do século XX. O "conto" é o "conte" francês, o "cuento" espanhol, o "tale" ou "short story" inglês, e indica sempre uma narrativa em prosa desenvolvida em poucas páginas. O termo novela, sobretudo

\footnotetext{
${ }^{47}$ MACCHIA, Giovanni. Premessa. In: Novelle per un anno. Op. cit, vol. 1, tomo 1, p. XVI.
} 
na Europa, traz a marca de um gênero prevalentemente italiano e, em particular, toscano, graças à fama do Decameron, mas mesmo na Itália, a partir do final do século XIX, foi gradativamente substituído pela palavra "racconto". Tanto que o termo "novela", em espanhol, e o termo "novel", em inglês, indicam o gênero literário romance e não a narração breve.

Existe, por outro lado, outra característica a ser considerada: a novela tem um caráter mais episódico e intuitivo do fato, está ligada ao acontecimento, enquanto o conto pode ser entendido como algo mais dilatado no tempo, desvinculado do fato, do evento, e possui uma implicação mais psicológica. Segundo Asor Rosa,

[...] a novela não é um gênero de argumento, de registro ou de destinatário. A única característica que os une é o seu caráter narrativo, ou seja, a evocação ou a representação de fatos aliada ao corte quantitativo que lhe é essencial. A novela é etimologicamente una 'nova', ou seja, uma notícia, é algo ligado à realidade. ${ }^{48}$

Nas primeiras novelas, aquelas de Boccaccio e do Novellino, o entrecho narrava uma espécie de armadilha, de brincadeira, de zombaria (beffa) que um dos personagens armava para o protagonista que tanto podia se safar através da inteligência ou mostrar-se um idiota ridículo, como é o caso do personagem Calandrino, ${ }^{49}$ de Boccaccio. Em Pirandello, a armadilha reveste-se de tons humorísticos, no sentido pirandelliano, e não é mais aplicada por um personagem, mas é a própria vida a prepará-la para o protagonista que, paradoxalmente, tenta escapar, não mais pela inteligência ou "esperteza", mas por um comportamento anômalo que muitas vezes será entendido como loucura ou fuga da realidade.

\footnotetext{
${ }^{48}$ ASOR ROSA, Alberto. La novella occidentale dalle origini ad oggi. Roma: Edizioni Moderne Canesi, 1960, pp. 9-17.

${ }^{49}$ BOCCACCIO, Giovanni. Decameron: Giornata VIII, Novella. III. Milano: Garzanti, 1976.
} 
Depois de um breve ressurgimento com Matteo Bandello no século XVI, a novela italiana que estivera em declínio por quase dois séculos, em parte por causa da censura da igreja, começa a ser resgatada por obra dos escritores românticos, desta vez, porém, numa tentativa moralístico-didática de educar as baixas camadas da população. São dessa época autores como Cesare Cantù, Giulio Carcano, Ippolito Nievo e Francesco Dall'Ongaro. No final do século XIX, Giuseppe Verga resgata definitivamente esse tipo de narrativa com o lançamento de duas coletâneas de novelas: Vita dei Campi e Novelle Rusticane. O verismo de Verga deixa de lado os ditos de espírito e as acrobacias verbais, presentes na tradição boccacciana, para examinar motivações internas e a influência do meio ambiente, limitando o peso da fatalidade que é típica das narrativas breves que nessa época também se desenvolveram em outros países como, por exemplo, a Rússia e a França. A novela passa a representar a irracionalidade da vida e a maneira pela qual o destino ou a "fortuna" condicionam e destroem seus protagonistas, sem entender, porém, a vida como agente intencional dessa destruição.

Segundo Salvatore Battaglia, Pirandello

desmonta cada vez mais a técnica da novela [...], a faz às vezes teatro, disputa, memória, protesto, solilóquio, investigação psicológica ou aforismo dialético, descrição empírica ou polêmica abstrata, e a insere em um grumo de pena, a dilata em uma caprichosa aventura do intelecto. ${ }^{50}$

A primeira produção novelística de Pirandello, de 1894 a 1903, segue esse filão desenvolvido por Verga e reproduz, grosso modo, duas dimensões fundamentais da vivência do autor: a siciliana, mais ligada ao campo e à Itália do sul, atrasada e quase feudal, e a

\footnotetext{
${ }^{50}$ BATTAGLIA, Salvatore. Pirandello narratore. In: Occasioni critiche: saggi di letteratura italiana. Napoli: Liguori, 1964, pp. 186-187.
} 
romana, da capital burguesa do início do século XX. A maioria destas novelas tem como fundo um tema amoroso sempre voltado para o sofrimento humano, a "pena di vivere". Parte delas foi recolhida nos volumes já citados: Amori senza amore (1894), Beffe della morte e della vita e Quand'ero matto... (1902). O sofrimento representado pela absoluta solidão do personagem, de seus gestos e de seus pensamentos, de suas palavras e de seus silêncios, são as bases lançadas pelo escritor para desenvolver sua poética e já pressagiam temas posteriores.

Em 1904, Pirandello publica seu primeiro grande sucesso narrativo: o romance $\mathrm{Il} f u$ Mattia Pascal. Esta obra, considerada polêmica à época, é um dos motivos que o leva a elaborar de maneira mais sistemática sua poética do Humorismo. Apesar de ser possível identificar com clareza traços do humorismo em Il Fu Mattia Pascal, é na novelística da fase que se inicia a partir daí que esta poética se realiza mais completamente. O ambiente passa gradativamente a segundo plano e o foco da narrativa está cada vez mais direcionado ao personagem que, na impossibilidade de uma vida completamente livre, passa a utilizar o discurso humorístico para desmascarar convenções, hipocrisias e mentiras da sociedade. São personagens derrotados que falam da impossibilidade de qualquer diálogo, da incomunicabilidade na vida quotidiana, como, por exemplo, o protagonista da novela "La trappola" (1912, US):

No, no, come rassegnarmi? E perché? Se avessi qualche dovere verso altri, forse sì. Ma non ne ho! E allora perché? Stammi a sentire. Tu non puoi darmi torto. Nessuno, ragionando così in astratto, può darmi torto. Quello che sento io, senti anche tu, e sentono tutti. ${ }^{51}$

\footnotetext{
51 "Não, não, como me resignar? E por quê? Se eu tivesse algum dever para com os outros, talvez sim. Mas não tenho! Então, por quê? Olha, você não pode dizer que estou errado. Ninguém, pensando abstratamente, pode dizer que estou errado. O que eu sinto, você também sente, e sentem todos." PIRANDELLO, Luigi. La trappola. In: Novelle per un anno, 3 vol. Op. cit., vol. 1, tomo 1, p. 775.
} 
De 1903 a 1928, Pirandello escreveu e publicou mais de 150 novelas, ${ }^{52}$ e os romances I vecchi e i giovani (1909), Suo marito (1911), publicado sucessivamente com o título Giustino Roncella nato Boggiòlo, Si gira... (1916), republicado posteriormente com o título definitivo de Quaderni di Serafino Gubbio operatore, e Uno, nessuno e centomila (1926). A grande virada na carreira "novellara" do agrigentino, porém, foi o início da colaboração, graças ao sucesso de Il Fu Mattia Pascal, no jornal "Corriere della Sera”, em 1909, no qual publicou até a véspera de sua morte. Algumas das novelas produzidas neste período foram reunidas nos volumes Bianche e nere e Erma bifronte (1904), La vita nuda (1910), Terzetti (1912), Le due maschere (1914), La trappola e Erba del nostro orto (1915), E domani, lunedì... (1917), Un cavallo nella luna (1918), Berecche e la guerra e Il carnevale dei morti (1919).

Em 9 de dezembro de 1910, aos 43 anos, Pirandello estréia como autor teatral com os atos únicos Lumie di Sicilia e La morsa, o primeiro elaborado a partir da novela homônima (escrita em 1900) e o segundo da novela L'epilogo (1898). A partir daí, ele se dedicará cada vez mais à atividade teatral, não apenas como autor, mas também como encenador e diretor de companhias teatrais. O teatro, que lhe trará fama mundial, é uma nova virada na carreira do escritor que de poeta torna-se narrador e de narrador transforma-se em dramaturgo. Ao invés de ser um prejuízo, essas reviravoltas acrescentam mais possibilidades à obra do siciliano que utiliza e reutiliza temas e personagens em uma espécie de intertextualidade interna ao próprio conjunto de sua obra. Isso levou alguns críticos a definir suas novelas como repositório de temas e personagens para a obra teatral. Contrariando essa perspectiva redutora, o que de fato se verifica é uma espécie de movimento circular e intercomunicativo entre os três gêneros, o que torna cada obra ao mesmo tempo única e completa em si mesma e passível de novas

\footnotetext{
${ }^{52}$ Ver gráfico anexo 1.
} 
leituras, aperfeiçoamentos e combinações para melhor representar um universo fragmentado, repleto de sofrimento e de tensões que regulam as relações entre os homens. Assim, por exemplo, o senhor Pinzone, preceptor do protagonista da novela "La scelta" (1898, A), é também o preceptor do jovem Mattia Pascal; o anjo Centuno da novela "Lo storno e l'angelo Centuno" (1910, NC) também é personagem do drama I giganti della Montagna (1936); a fábula do filho trocado, aprendida na infância, é tema da novela "Il figlio cambiato" (1902, NC) e do drama em versos La favola del figlio cambiato (1934); a peça que os atores de Sei personaggi in cerca d'autore (1921) estão ensaiando, e criticam, no início do drama, é Il giuoco delle parti (1918), do próprio Pirandello; os dois suicídios da novela "E due!" (1901, $\mathrm{SN}$ ), são feitos da mesma maneira que o falso suicídio de Adriano Meis, personagem de Il fu Mattia Pascal (1904).

No entanto, é somente a partir de 1916 que o teatro substitui gradualmente a novela. De 1917 a 1921, ano da estréia do drama Sei personaggi in cerca d'autore, são publicadas apenas 12 novelas, enquanto no período seguinte, até 1928, este número cai para 9. O grande sucesso no teatro, as constantes viagens e o público que exige sempre novas peças, obrigam o autor a diminuir a produção novelística.

Depois de dois anos sem publicar novelas, Pirandello retoma gradualmente a produção a partir de 1931, impulsionado pelo desejo de completar o projeto, iniciado em 1922, das Novelle per un anno. As novelas deste período, no entanto, apresentam características diferentes das anteriores e revelam personagens com desejo de anulação, de evasão do dia-adia para um plano superior de experiência; eles não falam mais da impossibilidade do diálogo ou da incomunicabilidade, preferem se calar e viver sem linguagem. É o que alguns críticos chamaram de "linguagem da evasão", atribuindo ao Pirandello maduro o título de "poeta do 
silêncio". ${ }^{53}$ Se no arco temporal em que desenvolveu sua obra Pirandello não alterou sua amarga visão da vida, o personagem, sensível ao momento cultural, recebe traços cada vez mais imprecisos e evanescentes, sugeridos por uma dimensão "surreal". Se não exatamente surreais, os personagens deste período apresentam um ar de irreversível estranhamento da vida. Não é mais a fuga do personagem para dentro de um espaço particular, muitas vezes confundido com a loucura, como, por exemplo, na novela "Il treno ha fischiato" (1914, US), na qual o protagonista (Belluca), ao ouvir o apito do trem, refugia-se em um mundo ideal, distante dos seus sofrimentos quotidianos, semeado de montanhas nevadas, horizontes azuis e densas florestas que, momentaneamente, tentam deter o fluxo da vida; trata-se de um outro tipo de alienação, uma inversão na ordem lógica das coisas que invade a consciência e produz um estado de sonho que destrói a percepção de tempo e espaço, levando deliberadamente à morte como única maneira de fazer cair a máscara.

Nessa última fase, Pirandello tenta recriar o movimento, já teorizado no ensaio L'umorismo, da divisão da psique do personagem que se desloca em direções opostas "avvertimento del contrario" e "sentimento del contrario" - criando um momento de extrema lucidez no qual o personagem toma consciência da sua verdadeira vida interior em momentos que, algumas vezes, precedem a morte física, como no caso da novela "Di sera, um geranio" (1934, BG).

Apesar dos títulos das últimas novelas parecerem-se muito com os das primeiras, em que a realidade é convencional, referindo-se a objetos como uma simples flor de jardim ou acontecimentos corriqueiros como uma visita, o autor siciliano narra experiências sob uma perspectiva que não pode ser atribuída a estruturas convencionais de tempo e espaço e nas quais a psique está em constante conflito e desintegração.

\footnotetext{
${ }^{53}$ Cfr. TERRACINI, Benvenuto. Le "Novelle per un anno" di Luigi Pirandello. In: Analisi stilistica. Milano: Feltrinelli, 1966, p. 369-395.
} 


\section{As Novelle per un anno.}

Por volta de 1922, Luigi Pirandello propõe-se a organizar e sistematizar definitivamente sua vasta produção de narrativas curtas, que naquele momento contava com aproximadamente 210 novelas publicadas, acumuladas desde 1894. Em um projeto unitário, que receberia o título de Novelle per un anno, pretendia reunir 365 novelas, uma para cada dia do ano, por um ano inteiro, sem que nenhuma delas tivesse as características de um determinado dia, mês ou mesmo de alguma estação.

Como procedera em suas obras teatrais, que vinham sendo reunidas desde $1918 \mathrm{em}$ um projeto que recebeu o título de Maschere Nude, Pirandello, já convencido e investido da sua profissão de "novellaro", talvez quisesse dar uma visão de conjunto à sua obra novelística, reunindo os escritos já publicados de maneira esparsa em jornais, revistas e em 14 volumes de coletâneas, cujos títulos, sempre remetendo às suas idéias sobre o humorismo, continham termos contraditórios, um pouco irônicos e quase sempre amargos: Amori senza amore (1894); Beffe della morte e della vita e Quand'ero matto... (1902); Bianche e nere e Erma bifronte (1904); La vita nuda (1910); Terzetti (1912); Le due maschere (1914); La trappola e Erba del nostro orto (1915); E domani, lunedì... (1917); Un cavallo nella luna (1918); Berecche e la guerra e Il carnevale dei morti (1919). 
A promessa, no entanto, não pôde ser cumprida devido à morte do autor em 1936. Sua atividade teatral e os constantes compromissos com turnês e filmagens, tanto na Itália como no exterior, não permitiram que ele completasse a cifra prometida das 365 novelas, legitimando assim, o título do projeto.

\subsection{Estrutura}

O plano da obra compreendia 24 volumes, cada um deles com 15 novelas. ${ }^{54} \mathrm{O}$ autor, no entanto, declarou à época que gostaria de vê-las publicadas em um único volume, o que, naquele momento era uma empresa impossível, uma vez que mais de um terço das novelas previstas ainda não havia sido escrita. Para a organização dos volumes, Pirandello revisou cuidadosamente cada novela, sendo que algumas, como "Pena di vivere così" (1920, IS), foram praticamente reescritas.

Os 13 primeiros volumes saíram pela editora Bemporad entre 1922 e 1928 e cada um deles recebeu o título da primeira novela do volume: Scialle nero, La vita nuda, La rallegrata e L’uomo solo (1922); La mosca e In silenzio (1923); Tutt'e tre (1924); Dal naso al cielo e Donna Mimma (1925); Il vecchio Dio (1926); La giara, Il viaggio, Candelora (1928). Em 1934, saiu o décimo quarto volume, Berecche e la guerra, e postumamente, em 1937, o volume Una giornata, ambos pela editora Mondadori, que havia comprado os direitos da obra. Em 1938 foi publicado mais um volume, também póstumo, que recebeu o título de

\footnotetext{
${ }^{54}$ Se fizermos as contas, 24 multiplicado por 15, perfaz um total de 360. Segundo Luperini: "De fato, será preciso supor que o autor teria parado nessa quota ou que teria acrescentado outras 5 novelas nos últimos volumes, para igualar o número de novelas ao número dos dias do ano." LuPERINI, Romano. Pirandello. Roma-Bari: Laterza, 2005, pp. 136-37.
} 
Appendice, no qual foram reunidas as novelas que o autor não havia incluído em volumes anteriores.

Nem todos os volumes contêm o número canônico de quinze novelas. Existem quatro volumes que não seguem esta regra, pois têm um número de novelas inferior a 15: no volume In silenzio encontramos, de fato, 13 novelas, porque a novela tripartida "Va bene" vale por 3; o mesmo acontece no volume Donna Mimma, onde a novela que dá título à coletânea também é dividida em três partes; no volume $I l$ vecchio Dio, temos 12 novelas que com a novela em quatro partes "Quand'ero matto..." completam o número estabelecido; e, por fim, no volume Berecche e la guerra, a novela epônima é composta por oito capítulos, aos quais foram acrescidas outras 7 novelas para compor a quota de 15. Assim, a atual edição das Novelle per un anno contém 225 novelas, às quais podemos acrescentar as outras 26 publicadas no volume Appendice, que talvez seriam recuperadas nos volumes seguintes, perfazendo um total de 251 novelas.

Os dois últimos volumes incluem, em sua maior parte, novelas escritas a partir de 1930, com a inserção de novelas escritas anteriormente para completar a cifra prevista de 15 . Trata-se de 19 títulos escritos ente 1930 e 1936: como se vê, é uma produção bem pequena se comparada à anterior, mas é possível afirmar, como veremos, que estas novelas têm uma maior homogeneidade de temas e linguagem, sendo mais representativas da maturidade do autor.

A crítica, até agora, não conseguiu respostas plausíveis para o critério de seleção adotado pelo escritor e para as relações entre os textos das novelas e o contexto dos vários volumes do corpus. Na organização das novelas, dentro de cada volume, o autor siciliano não utilizou a ordem precedente de publicação sendo que no primeiro volume (Scialle nero), encontramos textos produzidos num intervalo de mais de 20 anos, de 1894 - a novela "Se..." 
(1894, SN) - a 1920 - a novela "Rimedio: la geografia"(1920, SN). Além disso, Pirandello também não seguiu uma lógica facilmente reconhecível, uma vez que a disposição dos textos não é cronológica ou temática, e a relação, quando existe, entre as novelas de um mesmo volume, é tênue e difícil de identificar. ${ }^{55} \mathrm{Na}$ verdade, o critério temático parece pouco mais do que um pretexto para reunir o que, até o início do projeto, eram exemplares esparsos de uma produção fragmentária. Mas quanto a isso, o próprio Pirandello, devemos lembrar, já havia advertido:

Mi affretto ad avvertire che le novelle di questi ventiquattro volumi non vogliono essere singolarmente né delle stagioni, né dei mesi, né di ciascun giorno dell'anno. Una novella al giorno, per tutt'un anno, senza che dai giorni, dai mesi o dalle stagioni nessuna abbia tratta la sua qualità. ${ }^{56}$

Também é preciso lembrar que, com apenas 210 novelas já escritas no início do projeto, seria muito difícil, se não impossível, criar uma obra como a de Boccaccio em que as jornadas (aqui poderiam ser os volumes) tivessem um argumento comum como fio condutor. Como afirmou Pirandello, em 1922,

Queste novelle che vado raccogliendo sono in fondo quasi novelle nuove, tanto son corrette, mutate. Alcune sono addirittura riscritte. Non ho potuto, tuttavia, ordinare i volumi proprio come avrei voluto perché non sono ancora in possesso di tutta la mia produzione. ${ }^{57}$

\footnotetext{
${ }^{55}$ Recentemente, Emma Grimaldi (Il labirinto e il caleidoscopio. Percorsi di letture tra le "Novelle per un anno" di Luigi Pirandello), fez uma tentativa de definir uma relação entre as novelas, mas com resultados, ao que parece, nem sempre convincentes, apesar de propor algumas relações bem interessantes.

56 "Apresso-me em advertir que as novelas destes vinte e quatro volumes não pretendem ser representativas, nem das estações, nem dos meses, nem de cada um dos dias do ano. Uma novela por dia, por um ano inteiro, sem que nenhuma delas traga características dos dias, dos meses ou das estações." Cit. in LUPERINI, Romano. Introduzione a Pirandello. Op. cit., pp. 113-114.

57 "Essas novelas que estou reunindo são, no fundo, quase novelas novas, de tanto que são corrigidas, mudadas. Algumas são até reescritas. Não pude, no entanto, ordenar os volumes exatamente como gostaria porque ainda não tenho toda minha produção". PIRANDELLO, Luigi. Intervista con Diego Manganella. In: Saggi $e$ Interventi: Esternamenti. Op. cit., p. 1152.
} 
Certamente, ao reordenar todo seu patrimônio novelístico, Pirandello pretendia atribuir um caráter de atemporalidade à sua mensagem literária e sugerir uma fruição sincrônica das novelas, nas quais os personagens, com suas frustrações e sofrimentos, seriam pequenos e imutáveis "espelhos". Ou melhor, pequenos retratos da vida cotidiana, uma vida revelada nos seus mínimos e cruéis detalhes.$^{58}$ Não se deve, no entanto, entender a organização das novelas como uma tentativa de colocá-las em uma moldura (cornice) como fez Boccaccio no Decameron, pois era claro para Pirandello que a condição humana no caótico século XX, com suas guerras e incertezas, não caberia numa moldura harmoniosa.

O título Novelle per un anno, traz ainda o próprio conceito da espiral do tempo, em que cada ano se renova no seguinte, numa repetição infinita, permitindo ao leitor sempre novas leituras e reflexões. O caráter emblemático dessas novelas assim organizadas dentro da produção pirandelliana e, por isso mesmo, a própria razão de sua organização, foi ilustrado por Giovanni Macchia:

Lendo estas novelas uma após outra, não se percebem etapas possíveis pelas quais o caos, o caos pirandelliano, transforme-se em cosmo, mas apenas representações aparentes de um falso cosmo que quase irremediavelmente recomece a ser caos. ${ }^{59}$

\footnotetext{
${ }^{58}$ Apesar de a crítica ter consagrado na obra de Pirandello a imagem do "espelho", talvez uma representação mais apropriada ao conjunto das novelas, assim organizadas, seria a de um grande edifício que dispõe de tantas janelas abertas quantas são as novelas, cada uma delas focalizando um pequeno fragmento da vida, de maneira a formar um grande e torturante afresco. Restariam, porém, algumas janelas fechadas; estas seriam as novelas que faltaram para completar o projeto.

${ }^{59}$ MACCHIA, Giovanni. Premessa. In: Novelle per un anno. Op. cit, vol. 1, tomo 1, p. XIX.
} 


\subsection{Personagens e conteúdo}

Se durante o período em que Pirandello desenvolveu sua obra ele não alterou sua amarga visão de mundo, a escrita, entretanto, sensível ao momento cultural, desenhou na fisionomia do personagem os sinais das diferentes fases; e, se no início, o personagem teve os traços bem marcados do verismo, depois, nas últimas novelas, esses traços passam a ser quase indecifráveis. A leitura sincrônica dos textos, da maneira como o autor os organizou nas Novelle per un anno não evidencia essas mudanças. Assim, é preciso escolher a linha diacrônica de publicação (na falta de dados relativos à data de composição) para recuperar o desenvolvimento dos elementos formais e de conteúdo ocultos na labiríntica ordenação da coletânea de 1922. Um percurso não muito fácil, mas que permite recompor alguns dados autobiográficos que o autor, mais do que em outras obras, imprimiu nas Novelle per un anno.

Considerando a seqüência temporal original de publicação, 11 das primeiras 13 novelas são estruturadas em torno de um tema amoroso, o mesmo que inspira o romance L'esclusa, composto em 1893. Os personagens sofrem, humoristicamente, com "amori senza amore", amores reprimidos, frustrados, traídos, brutalizados pelo ciúme, sublimados na memória, mas que sempre dão vazão a uma inextinguível ânsia de viver. De 1884 (data de publicação de "Capannetta") até 1911, 51 novelas em 130 ainda são ligadas ao tema amoroso, mas nas últimas, publicadas de 1921 a 1936, em sintonia com um pessimismo cada vez maior, 21 em 32 falam da angústia da morte, da doença e da velhice, que também é a velhice do autor, em que, acabados os amores, a esperança e o desejo, não é possível mais suportar o mundo.

Ainda utilizando uma investigação diacrônica, é possível localizar 6 novelas, distribuídas em vários volumes, inspiradas na Primeira Grande Guerra: "Berecche e la 
guerra", (1914, BG), "Colloquii coi personaggi” (1915, VD), "La camera in attesa" (1916, C), “Quando si comprende" (1918, DM), “Jeri e oggi" (1919, NC) (continuação da anterior) e "Frammento di cronaca di Marco Leccio e della guerra sukka carta nel tempo della grande guerra europea" (1919, A). Nelas, o autor parece dividido entre a paixão interventista, ${ }^{60}$ alimentada pelas tradições ressurgimentais da família, o horror pelas inevitáveis atrocidades bélicas e a filosófica contemplação dos eventos, em uma não muito isenta perspectiva histórica, uma vez que seu filho Stefano foi prisioneiro dos austríacos. O período da guerra, além da prisão do filho, parece ter marcado muito Pirandello, pois coincidiu também com o agravamento do estado mental da esposa e a morte da mãe.

A tragédia da guerra inicia uma espécie de dissolução da poética do humorismo em que o "sentimento do contrário", que revelava, em ocasiões de riso fácil, aspectos dolorosos da realidade, passa gradativamente a ter como ponto de partida o riso amargo e sem graça. No tormento cotidiano da "grande carnificina" da guerra, não há mais lugar para filtros que disfarcem o confronto doloroso com as desventuras e as aflitivas razões da realidade, que desorganizam as defesas fictícias impostas pelo humorismo.

Nas novelas posteriores à guerra, as temáticas, cada vez mais marcadas pelo pessimismo, vão muito mais fundo do que as anteriores na busca das razões do sofrimento. Se antes o personagem, ferido nas relações familiares e sociais, traído em sua ingenuidade pela hipocrisia e oportunismo dos outros, tentava se defender de maneira exasperada e paradoxal, tomando atitudes antagônicas irredutíveis, agora ele procura a solidariedade e, às vezes, a compreensão. Basta comparar a disputa que se trava em "La Giara" $(1909, \mathrm{G})$ entre o patrão don Lollò Zirafa e o consertador de jarros zi' Dima Licasi, ou na determinação Chiàrchiaro, de "La Patente" (1911, US), diante da "schifosa umanità" dos concidadãos que lhe atribuíram a

\footnotetext{
${ }^{60}$ Orientação política que propunha a intervenção militar da Itália na Primeira Guerra.
} 
fama de trazer mau-olhado, com a relação de humana cordialidade que se estabelece, em "La Cattura" $(1918, \mathrm{G})$, entre os seqüestradores inexperientes e sua vítima, um velho proprietário de terras, ou no encontro de dois antigos rivais, em "Sedile sotto un vecchio cipresso" (1924, DM), aproximados pela doença e pela velhice numa espécie de piedade terminal.

Nas Novelle per un anno, os espaços em que os personagens circulam coincidem com aqueles freqüentados e vividos pelo autor: Agrigento com a vila natal Caos, a marina de Porto Empedocle, os vilarejos vizinhos, e Roma, a maior cidade italiana; e cada uma delas contribui de maneira diferente para a composição temática das novelas.

Agrigento, cidade que conserva todas as características de uma Itália quase feudal, castigada pelo sol, ainda marcada pela crendice e pela superstição, fornece situações e personagens ligados à terra e ao meio rural, na maioria das vezes atormentados pela falta de recursos, de perspectivas, e ameaçados por sócios infiéis, especuladores e pelos próprios patrões. São proprietários de terras, de minas de enxofre, arrendatários, empreiteiros, usurários, todos oprimidos pela ruína econômica e marginalidade social. Na luta pela sobrevivência, aparecem camponeses, serviçais, mineiros, escriturários e mendigos; na política provincial encontramos representantes do governo, da igreja, socialistas e alguns remanescentes da geração garibaldina. Os temas ainda são muito ligados ao verismo, mesmo que seja um verismo ou naturalismo cada vez mais negado em seus pressupostos essenciais. Esses personagens, em sua maioria, povoam as primeiras novelas tendendo a desaparecer nas novelas finais, ou a terem menos marcados os traços ligados à terra.

A área romana serve como pano de fundo para frustrações existenciais, incomunicabilidade, solidão e discussões mais passionais. A estratificação social dos personagens romanos é variada: junto a exemplares do mundo parlamentar e acadêmico, 
aparece um vasto número de funcionários públicos, escrivães, aposentados, trabalhadores no comércio, aspirantes frustrados à glória literária e artística, costureiras, balconistas, babás e cantoras de café-concerto obrigadas a se prostituir por necessidade. Os personagens romanos, em seu caráter burguês, não se diferenciam muito daqueles que habitam outras cidades italianas, como Nápoles ou Florença, ou as cidades no exterior, como Bonn ou Nova Iorque: cidades estas que também fazem parte da biografia do autor. Mas a geografia, em termos de cidades, condiciona apenas parcialmente os personagens; o mais importante é sua tipologia humana que se impõe sobre o ambiente. Como afirmou Petrônio, trata-se aqui de

$$
\begin{aligned}
& \text { um grupo }[\ldots] \text { de novelas "ideológicas", de ambientação citadina e } \\
& \text { construídas sobre temas que se costumou chamar de "pirandellianos": } \\
& \text { dissolução da consciência, negação de qualquer verdade objetiva, } \\
& \text { relativismo, pena di viver e a piedade desta pena. }{ }^{61}
\end{aligned}
$$

Com certeza, as Novelle per un anno são o autêntico testamento de Luigi Pirandello e o testemunho do minucioso e completo estudo a que o autor se dedicou durante toda sua vida literária. São uma espécie de "bloco de notas" ao qual ele confiou suas observações sobre a vida para tentar compreender o absurdo da aventura humana com suas cenas sempre muito diversificadas, de um espetáculo ora cômico, ora trágico, e quase sempre grotesco, e seus personagens com seus desejos e ódios, amores e necessidades.

Gente da cidade e do campo, movimentando-se nos ambientes pequeno-burgueses de Roma ou nas pobres regiões do interior da Sicília, os personagens das novelas de Pirandello podem ser consideradas como um microcosmo representativo de toda uma humanidade,

\footnotetext{
${ }^{61}$ PETRONIO, Giuseppe. Le novelle surrealistiche di Pirandello. In: Le novelle di Pirandello (S. Milioto org.). Atti del Convegno di Studi, Agrigento, 6-10 dicembre 1979. Agrigento: Edizioni del Centro Nazionale di Studi, 1980, p. 211.
} 
suportando uma vida amarga, muitas vezes resignados e trazendo dentro de si uma quase maldição atávica. Seu comportamento com relação à vida, quando tentam se livrar do torpor da resignação que os oprime, ou é uma rebelião sem sentido que os isola numa profunda solidão, ou uma alienação de tudo e de todos que os leva a um sofrimento ainda maior. O personagem pirandelliano carrega dentro de si um forte instinto de rebelião, incorporando e reproduzindo o que seria o desejo comum a todos nós, de vida e de liberdade, que faz com que ele, antes de se render à inevitável derrota que o espera, se debata, indague e sofra à procura de uma explicação; um caminho que, pelo menos, torne aceitável o destino que lhe foi assinalado, mesmo sabendo que não poderá fazer mais do que aceitar a derrota.

Na novela "La distruzione dell'uomo" (1921, M), por exemplo, Nicola Peti, depois de ter se dado conta, a duras penas, da inutilidade da vida, decide eliminá-la pela raiz afogando uma mulher que espera seu décimo sexto filho, pensando assim exterminar na criança todos os homens. Já em “Canta l'Epistola” (1911, R), o protagonista, depois de ter chegado à mesma conclusão sobre a irracionalidade da vida, pratica conscientemente uma espécie de suicídio interior, anulando-se na vida de uma folha de grama.

Todo o personagem pirandelliano está sempre à procura de um remédio para sua miséria existencial, mas este remédio nunca é algo de positivo ou construtivo: em geral é a anulação psíquica do próprio indivíduo, ou a loucura, uma loucura que se realiza na violência ou na descoberta de uma dimensão de vida artificial. Assim, o protagonista de "Rimedio: la Geografia" (1920, SN), cansado de cuidar da mãe moribunda, descobre nas cartas geográficas a única possibilidade de evasão, mesmo fictícia, para a insipidez de uma vida sem sentido. Do mesmo modo, na novela "Il treno ha fischiato" (1914, US), o protagonista encontra um precário equilíbrio na dimensão onírica para onde é quase obrigado a se transportar para fugir da mediocridade de uma existência sem esperanças. Da mesma forma, o professor 
Maraventano, em "Pallottoline!" (1902, G), refugia-se no Observatório de Monte Cavo e se perde com a mente no espaço, para não sentir a dor das misérias da vida, enquanto o doutor Fileno, em "La tragedia d'un personaggio" (1911, US), cria para si uma filosofia de vida, a filosofia "del lontano", que para expulsar da mente a dor causada por um fato presente, imagina que este aconteceu em um passado já remoto.

No entanto, nem todos os personagens têm o privilégio de conseguir escapar da vida, dominada, além das misérias humanas, também pela incompreensão na qual cada um é obrigado a viver. A maioria deles está condenada a permanecer, para sempre, prisioneira e vítima da triste realidade cotidiana. Todos os personagens das novelas, tanto aqueles que se "salvam" na loucura ou no sereno mundo das fugas fictícias quanto aqueles que permanecem escravos da "pena di vivere", são derrotados por uma vida que sempre lhes é estranha e hostil, apesar de nunca abandonarem a luta para encontrar sua identidade e um lugar na sociedade que não os compreende e marginaliza. Por isso, tanto nos ambientes pequeno-burgueses quanto nas pobres regiões sicilianas, debatem-se homens permanentemente angustiados, sempre à procura de um meio para melhorar ou afirmar sua posição social, e sempre rechaçados por um destino cruel, como acontece, por exemplo, em "Le tre carissime" (1894, VD), com as filhas de um aposentado, ansiosas para encontrar marido, ou, em "L'amica delle mogli” (1894, A), com os rapazes interioranos que não conseguem pedir a mão de uma jovem de família, bem de vida, intimidados pela exuberante elegância da cidade.

Assim, todos os personagens pirandellianos, apesar das diferenças sociais ou culturais, sofrem a mesma condenação à derrota na luta pela existência: qualquer rebelião é vã e toda vez que, consciente ou inconscientemente, esforçam-se para sair da condição em que foram relegados pela vida, sofrem uma espécie de desintegração total de sua personalidade e de sua vontade que os conduz à derrota total. O homem pirandelliano encontra-se, portanto, imerso 
numa solidão sem fim, excluído do mundo e de seus semelhantes com os quais não consegue se comunicar, vencido por acontecimentos que não é capaz de dominar e com a personalidade destruída, sempre só e sofrendo até a morte, qualquer que ela seja: em um leito de hospital, sozinho, repetindo febrilmente os movimentos do trabalho que fez em vida - "La mano del malato povero" $(1915, \mathrm{~V})$, ou em uma miserável cama de hotel - "Nell'albergo è morto un tale" (1915, C), ou no seu próprio berço, sem ter conhecido o afeto materno - "L'ombrello" $(1909, \mathrm{~V})$.

A existência não oferece nada ao homem pirandelliano, a não ser dor e, com sorte, loucura: loucura como forma de rebelião, pois se o indivíduo reage, é no papel de louco. Como o protagonista de "Fuga" (1923, NC), o senhor Bareggi, que, sofrendo de muitos males, mas principalmente de uma sufocante monotonia em seu trabalho, um dia salta na carroça do leiteiro e lança o cavalo em uma corrida desenfreada pelas ruas da cidade até alcançar o campo, talvez à procura da liberdade e de si mesmo. Para os que decidem vivê-la, a vida acaba por se transformar em uma terrível armadilha de morte; aliás, como em L’umorismo, ela é a própria morte e todos os homens, mortos inconscientes, como fica evidente na novela "La trappola" (1912, US): "siamo tanti morti affaccendati, che si illudono di fabbricare la vita, ma invece generano morte". ${ }^{2}$

Não menos doloroso é o quadro da existência humana mostrado nas novelas de ambiente siciliano. Em sua maioria pertencentes às duas primeiras fases do escritor, elas são fruto de uma escolha artística em que se misturam o amor pela terra natal, a dolorosa consciência das culpas atávicas na alma de seus conterrâneos e as responsabilidades não apenas históricas, mas também sociais e morais de toda uma coletividade. Essas novelas

\footnotetext{
62 "somos tantos mortos atarefados, que se iludem de fabricar a vida, mas, ao contrário, geram morte". PIRANDELlO, Luigi. La trappola. In: Novelle per un anno. Op. cit, vol. 1, tomo 1, p. 778.
} 
oscilam, umas mais outras menos, entre o amargo sarcasmo das condenações sem recurso e o não menos amargo sentimento de piedade pelos destinos fadados - sem culpa de ninguém ou por culpa de todos - à falência inevitável.

Sob muitos aspectos, as narrativas que têm como pano de fundo a Sicília podem ser caracterizadas por uma maior liberdade de imagens, um maior despojamento de representação, mas, ao final das contas, quando a novela termina, os personagens sempre se encontram nas mãos de um destino que os leva à marginalização e à morte. Os personagens sicilianos são plenos de vitalidade e mais bem delineados que aqueles da cidade, mas todos se arrastam pela vida com dificuldade, vítimas de circunstâncias e situações que os oprimem e humilham, como o epilético Bata, em "Male di luna" (1913, NC), que sofre em silêncio suas transformações em lobisomem, ou o protagonista de "Ciàula scopre la luna" (1912, NC) que, sempre afundado nas entranhas da mina, obrigado a trabalhar e humilhado pelo capataz, descobre a lua, para consolo de seus males e medos:

E Ciàula si mise a piangere, senza saperlo, senza volerlo, dal gran conforto, dalla grande dolcezza che sentiva, nell'averla scoperta, là, mentr'ella saliva pel cielo, la Luna, col suo ampio velo di luce, ignara dei monti, dei piani, delle valli che rischiarava, ignara di lui, che pure per lei non aveva più paura, né si sentiva più stanco, nella notte ora piena del suo stupore. ${ }^{63}$

Um tema muito freqüente nas novelas sicilianas é o do marido traído, mas a comicidade com que é tratado é apenas aparente: em "Al valor civile" (1902, VD), Bruno Celèsia salva de morrer afogado ninguém menos do que o amante da esposa; na novela "Certi

\footnotetext{
63 "E Ciàula começou a chorar, sem perceber, sem querer, pelo grande conforto, pela grande doçura que sentia, por tê-la descoberto, lá, enquanto ela subia no céu, a Lua, com seu amplo véu de luz, ignorante dos montes, das planícies, dos vales que iluminava, ignorante dele, que também não tinha mais medo dela, nem se sentia mais cansado, na noite agora plena de seu espanto." PIRANDELLO, Luigi. Ciàula scopre la luna. In: Novelle per un anno. Roma: Newton Compton Editori, p. 705.
} 
obblighi” (1912, NC), Quacquèo, o marido traído, obrigado pela população que o desafia a surpreender em flagrante a esposa, para vingar sua honra diante da coletividade, esconde o amante em um armário e abre a janela para gritar à multidão furiosa: "Non c'è nessuno! Apro la porta... Chi vuol salire, salga; se volete accertarvene. Ma non c'è nessuno!"64 Na verdade, mesmo as novelas que se destacam pela comicidade, como "La giara" (1909, G), com seu grupo de camponeses alegres e cheios de vida, trazem, em concordância com a poética do Humorismo, um tom sarcástico, onde a comicidade é apenas um véu que cobre a amargura da sátira social.

Considerando que as novelas foram escritas durante um período de mais quarenta anos e que abrangem praticamente toda a escala social, a Itália de norte a sul (com algumas referências ao exterior) e uma infinita série de tipos humanos, elas, de certa forma, apresentam uma profunda unidade temática, formando um grande afresco do sofrimento absurdo e cruel que atinge todos os homens que torna estéril qualquer tentativa de rebelião e os condenando a uma eterna solidão.

Nesse sentido, as novelas pirandellianas, em seu conjunto, não fazem mais do que espelhar a crise - crise social, mas principalmente moral - da sociedade italiana, e européia, do final do século XIX e início do século XX, com suas tentativas de rebelião e redenção, com suas frustrações, escândalos, angústias e medos. O super-homem dannunziano é um mito para poucos e, além do mais, destinado a também sofrer graves desilusões; os vencidos de Verga suportam o sofrimento sem se rebelar, sem ilusões; mas a vida verdadeira é algo de triste e miserável contra a qual os personagens de Pirandello se rebelam na tentativa de não sofrer toda a sua negatividade.

\footnotetext{
${ }^{64}$ Não tem ninguém! Vou abrir a porta... Quem quiser subir que suba; se vocês querem ter certeza. Mas não tem ninguém!” PIRANDELlO, Luigi. Certi obblighi. In: Novelle per un anno. Op. cit., p. 701.
} 
Dessa forma, ao organizar suas novelas em um labiríntico e quase insondável conjunto de idéias e sentimentos, Pirandello não poderia, nem era sua intenção, se ater apenas à representação de fatos, mas fazer uma reflexão contextualizada sobre eles, ou seja, refletir sobre a falência do indivíduo diante das obscuras finalidades da existência, em um estudo preciso e detalhado da psique humana quando levada à condições extremas.

\subsection{As últimas novelas}

Como já mencionado, Pirandello diminui sua produção de novelas a partir de 1921 (ano da estréia de Sei personaggi in cerca d'autore), devido ao sucesso alcançado pelo seu teatro, as obrigações e funções que é obrigado assumir. $\mathrm{O}$ teatro parece consumir todo seu tempo disponível para outras atividades, inclusive a de professor, não lhe restando tempo para a produção narrativa.

Entre 1921 e 1928, foram publicadas apenas 10 novelas, além de seu último romance Uno, nessuno e centomila (1926), depois de uma gestação de mais de 12 anos. Essa interrupção também reflete um momento de transição que, já no último romance, apontava o aparecimento de uma fase mais centrada na interioridade do personagem e na tentativa de sua reconstrução.

Apesar das vicissitudes, a vontade de concluir o projeto das Novelle per un anno ainda impulsionava o escritor para a narrativa curta. O próprio Pirandello parecia ter consciência de que esta nova fase poderia render mais e melhores frutos quando, em 1935, decidido a completar seu projeto, escreveu ao diretor do "Corriere della Sera", Aldo Borrelli: 
"Vi mando, appena tornato da New York, questa novella, e Vi prometto che riprenderò regolarmente la mia collaborazione perché è ferma mia intenzione compire le mie Novelle per un anno." 65

Depois de dois anos sem publicar narrativa (1929 e 1930), Pirandello recomeça lentamente seu trabalho com as novelas, publicando até sua morte 21 escritos que, em sua maioria, estão reunidos nos dois últimos volumes das Novelle per un anno. ${ }^{66}$

Estas últimas novelas apresentam características bem diferentes das anteriores, tendo sido denominadas "surreais"por alguns críticos. Um surrealismo, porém, muito particular, como toda a obra de Pirandello, que não pode ser comparado ao surrealismo francês, e nem mesmo ao gênero praticado pelos seus contemporâneos Buzzati e Bontempelli, mas que pode ser descrito como um irreversível estranhamento da vida que coloca o personagem diante de uma nova possibilidade de escapismo, um escapismo mais próximo da redenção, mais ligado à dissolução do personagem e sua reconstrução na natureza.

Como afirmou Petrônio, estas novelas revelam uma nova dimensão do autor, são menos estilisticamente carregadas e

menos inclementes, [...] o léxico, o estilo, a música do discurso tornam-se mais leves, em um esforço evidente para encontrar os tons necessários para aquele mundo de impressões e sensação esfumadas, surreais ou irreais. ${ }^{67}$

A relação com o mundo externo, superficial e angustiante, é representada por um contato alienante de quem se sente perdido em um lugar que não conhece ou não reconhece, como acontece ao anônimo passageiro jogando para fora de um trem em "Una giornata"

\footnotetext{
65 "Envio-lhe, recém chegado de New York, esta novela, e prometo que recomeçarei regularmente minha colaboração, pois é firme minha intenção de terminar as minhas Novelle per un anno.". PIRANDELLO, Luigi. Carteggi inediti: con Ojetti, Albertini, Orvieto, Novaro, De Gubernatis, De Filippo. Sarah Zappulla Muscarà (org.). Roma: Bulzoni, 1980, p. 241.

${ }^{66}$ Ver relação completa das novelas escritas entre 1930 e 1936 no Anexo 2.

${ }^{67}$ PETRONIO, Giuseppe. Le novelle surrealistiche di Pirandello. In: Le novelle di Pirandello. Op. cit., p. 211.
} 
(1936, UG). Nesta novela que finaliza o último volume das Novelle per un anno, por exemplo, o autor traça alegoricamente a jornada da vida, onde o tempo, como o trem que deixou o protagonista na estação, nunca pode ser detido e atinge seu momento culminante na consumação do amor que também é morte, na cama que se transforma em tumba. Pirandello retrata nesta novela o momento particular da vida no qual o homem moderno, depois de ter perdido qualquer relação com o mundo externo, e tendo sido suspensa qualquer dimensão de tempo, compreende a inconsistência de todas as coisas e a sua incapacidade de comunicação com a sociedade e com o mundo. É um momento de vazio, como se a vida não lhe pertencesse, e de evasão, já que a vida tem sentido próprio que não pode ser detido; é um momento de silêncio absoluto, em que o protagonista tenta escutar e compreender suas razões interiores.

E se a realidade não serve mais como referência para a representação, a língua das últimas novelas atenua sua função referencial para se transformar em uma comunicação interior, nitidamente emotiva. É bom lembrar que a linguagem de Pirandello, antes de se decantar nessas tardias provas narrativas, era caracterizada pela mimese naturalista da língua falada, repleta de termos e locuções sicilianas conscientemente italianizadas e de numerosos toscanismos, em um tecido lingüístico heterogêneo entremeado de vocábulos consagrados da tradição literária italiana, sugerindo um propósito "anti-literário", de maneira a melhor representar o substrato social narrado. Para Romano Luperini,

O próprio Pirandello, neste período, parece particularmente sensível à exigência de uma mensagem positiva e às vezes [...] explicitamente ideológica, que modifique sua imagem aos olhos dos leitores e dos espectadores e atenue os elementos desagregantes e amargamente humorísticos da própria arte. ${ }^{68}$

\footnotetext{
${ }^{68}$ LUPERINI, Romano. Pirandello. Op. cit., p. 152.
} 
Assim, as novelas da sua última fase, parecem reunir e resumir a posição histórica do autor, a dissolução de qualquer certeza, de qualquer ideal retoricamente ostentado, da ética, da metafísica e da própria história, retirando a máscara da nossa existência no mundo para buscar o íntimo do personagem e mostrar que a vida, apesar de não ser mais do que caos, destruição, loucura e morte, pode ser encarada com menos hostilidade, pois talvez permita uma espécie de "renascimento" àqueles que compreendem o jogo. 


\section{A jornada final}

As novelas compostas a partir de 1931 representam um grupo mais reduzido (21 novelas, das quais 19 publicadas nas Novelle per un anno) e cronologicamente destacado das anteriores devido a um período de recesso do escritor, pelos motivos já relatados. Apesar de darem continuidade a muitos dos temas explorados por Pirandello, elas apresentam características de estilo e tema que as diferenciam das precedentes, principalmente por terem uma linguagem estilisticamente menos carregada, menos terrena e, em certo sentido, menos grotesca.

Em sua maioria, falam de sensações que vão além do real, de aventuras negadas aos homens deste mundo, de um retorno à natureza, de dissipação e morte. Por isso, muitos críticos leram nessas novelas um tom ou um clima surrealista e, como Terracini, identificara na obra de Pirandello, na sua trajetória novelística principalmente, um processo que vai do "pseudorealismo inicial à exasperação progressiva de todos os aspectos de relativismo até a evasão surrealista", ${ }^{69}$ o que reproduz, de certa maneira, o trinômio contato com o mundo/procura de uma explicação/a realidade "outra". Por sua vez, Leone De Castris, em sua Storia di Pirandello, define a última fase de Pirandello uma "veleidade surrealista", que decompõe o drama das criaturas da própria arte "em momentos de

\footnotetext{
${ }^{69}$ TERRACINI, Benvenuto. Le "Novelle per un anno" di Luigi Pirandello. In: Analisi stilistica, Op. cit., p.
} 322. 
absoluta e desesperada gratuidade ontológica, em simples fragmentos de percepção"; um mergulho na escuridão do irracional e uma "evasão surreal" que, segundo ele, significam e comportam uma involução e desagregação da arte de Pirandello, o qual, assim, se aproximaria do curso do pensamento e da consciência européia, mas se afastaria do caminho que ele havia seguido até então, e da lógica deste caminho. ${ }^{70}$

Apesar de similares, são duas análises que apresentam divergências importantes para o mesmo grupo de escritos. Enquanto Terracini, fazendo uma análise estritamente estilística, rejeita qualquer relação, ou possibilidade de uma relação de dependência entre a obra de Pirandello e o curso histórico e social de seu tempo, e insiste continuamente no caráter completamente pessoal, completamente individual, da psicologia e do estilo do autor, sem buscar o que existe nele de novo, original, e fruto de uma participação na vida sócio-histórica da época, com a variedade e complexidade infinita de suas articulações, De Castris chega a conclusões que diminuem a consistência artística da obra de Pirandello em sua última fase, e, mesmo identificado-a com o momento histórico, sugere uma incompatibilidade instintiva entre o irracional e o surreal, a natureza do escritor e a lógica de sua arte

A obra de um escritor pode ser concebida como um processo contínuo que, em relação e à semelhança do curso da história, às vezes evolui de maneira uniforme e às vezes avança por saltos e rupturas, sendo sempre passível, no entanto, de ser organizada em fases que guardam alguma relação entre si. Cada fase permite uma análise e julgamento segundo sua lógica interna e segundo os elementos que motivam seu desenvolvimento, que se articula a partir das experiências vividas. Assim, não se poderia definir esta fase como uma involução, como o quer De Castris. Se Pirandello, em seus últimos anos, julgou insuficien-

\footnotetext{
${ }^{70}$ Cfr. DE CASTRIS, Leone. Storia di Pirandello. Bari: Laterza, 1962, respectivamente nas páginas 179 ,
} $189,191,194$ 
te os instrumentos de análise do real (psicológico e social) utilizados até então e procurou e experimentou outros, enveredando pelo fabuloso, pelo mito e pelo surreal, deve-se considerar suas razões, decorrentes, sem dúvida, do extenso e minucioso estudo que o levou à constatação de uma realidade "outra" (ou ao esboço desta constatação, já que ficou inacabado) de um novo sistema, e não à mera introdução de fatos novos em um tecido antigo. Da mesma forma, sua nova arte tem estreita correspondência com o momento sócio-cultural europeu e, sobretudo, italiano.

Não seria arbitrário, portanto, isolar este grupo de novelas e estudá-lo separadamente sem, no entanto, destacá-lo do tronco de toda a novelística de Pirandello.. Lendo estas novelas, mesmo sem muita atenção, como observa Moestrup, ${ }^{71}$ fica evidente que elas têm uma "distinct unity", ou seja, constituem, sem invalidar a obra precedente, um bloco unitário, com algumas características que lhe são peculiares.

\subsection{Temática}

Analisando os temas desenvolvidos neste bloco unitário, vemos que se distanciam bastante dos que eram freqüentes nos primeiros escritos do autor que, como já mencionado, eram em grande parte de fundo amoroso. Agora, a temática gira principalmente em torno de dois pólos que às vezes se comunicam: a morte e a oposição entre o mundo do homem (a cidade) e o mundo da natureza (o campo). Não que estes temas não estivessem presentes nas novelas anteriores, mas a perspectiva é outra, a linguagem mais leve estilisticamente e

\footnotetext{
${ }^{71}$ Moestrup, Jørn. The structural patterns of Pirandello's work, Odense, University Press, 1972, p. 252
} 
há muitos momentos de epifania. Romano Luperini, ${ }^{72}$ com base em Petronio, ${ }^{73}$ também identifica essas temáticas nas últimas novelas e as relaciona com uma necessidade do autor em encontrar "outra" ordem das coisas, que permita "revelar e celebrar liricamente o Ser em sua imobilidade a-histórica" ${ }^{74}$ o que comporta uma reconstituição da identidade pessoal, sem interferências externas, sociais ou históricas. Devemos lembrar que estamos no período da consolidação do Fascismo e que esta celebração do Eu pode ser antes entendida como a reação de Pirandello à radicalização de seu pessimismo, motivado principalmente pelos fatos históricos e econômicos da época. A visão pirandelliana da vida sempre foi de um relativismo desesperado para o qual contribuíram várias razões: motivos de natureza psicológica, experiências de vida, tomada de consciência da vida social, cultural e da atmosfera de seu tempo. É de se supor que essas razões nunca operem separadamente, mas que se sobrepõem e combinam em uma síntese que corresponderia à natureza de cada um; por isso, não é possível tentar detectar somente fundamentos psicológicos, ou culturais, ou sociais em sua obra.

Em sua visão desesperada e angustiada da vida e do homem, Pirandello nunca chegou a identificar, como Leopardi, a causa da "pena di vivere" em uma força indiferente e cruel emanada da natureza, ou como Svevo, em uma “doença” incurável cuja solução única seria a destruição do próprio mundo. Ao que tudo indica, ele define as causas últimas do sofrimento como humanas e sociais, podendo ou não ser influenciadas por razões econômicas ou políticas:

\footnotetext{
${ }^{72}$ LUPERINI, Romano. Pirandello. Op. cit.

${ }^{73}$ PETRONIO, Giuseppe. Le novelle surrealistiche di Pirandello. In: Le novelle di Pirandello. Op. cit.

${ }^{74}$ PETRONIO, Giuseppe. Le novelle surrealistiche di Pirandello. In: Le novelle di Pirandello. Op. cit. p. 153.
} 
Quanto più difficile è la lotta per la vita e più è sentita in questa lotta la propria debolezza, tanto maggiore si fa poi il bisogno del reciproco inganno [...] Il mentire a noi stessi, vivendo coscientemente solo la superficie del nostro essere psichico, è un effetto del mentire sociale. L'anima che riflette sè stessa è un'anima solitaria; ma non è mai tanta la solitudine interiore che non penetrino nella coscienza le suggestioni della vita comune, con gl'infingimenti e le arti trasfigurative che la caratterizzano. Vive nell'anima nostra l'anima della razza o della collettività di cui siamo parte; e la pressione dell'altrui modo di giudicare, dell' altrui modo di sentire e di operare, è risentita da noi inconsciamente: e come dominano nel mondo sociale la simulazione e la dissimulazione, tanto meno avvertite quanto più sono divenute abituali, così simuliamo e dissimuliamo con noi medesimi, sdoppiandoci e spesso anche moltiplicandoci. $^{75}$

Ou seja, já em 1908, Pirandello percebia que o sofrimento humano deriva de um mal social, de um mal que nos obriga a um "mentir social" e que, apesar de muitas vezes passar despercebido, influencia nossas atitudes e posturas diante dos nossos sentimentos mais íntimos. Aliás, é exatamente esse caminho que nosso autor toma quando parte à procura de uma explicação, na medida em que, lentamente, vai transferindo o ambiente de suas novelas da longínqua Sicília camponesa para a Roma médio-burguesa. A cidade, enquanto lugar de maior densidade de vida social, onde o homem vive em estreito contato com outros homens é, sem dúvida, o lugar de máxima alienação e sofrimento. E a solução que Pirandello vai buscar é uma só: a "natureza", onde o homem não está mais em contato

\footnotetext{
75 "Quanto mais difícil é a luta pela vida e mais sentida nesta luta a própria fraqueza, maior se faz a necessidade de um engano recíproco [...] Mentir a nós mesmos, vivendo conscientemente apenas a superfície de nosso ser psíquico, é um efeito do mentir social. A alma que reflete a si mesma é uma alma solitária; mas nunca há uma solidão interior tão grande que não penetrem na consciência as influências da vida comum, com simulações e as artes transfigurativas que a caracterizam. Vive em nossa alma, a alma da raça ou da coletividade de que somos parte; e a pressão do modo de julgar dos outros, do modo de sentir e operar dos outros, nós sentimos inconscientemente: e como dominam no mundo social a simulação e a dissimulação, tanto menos percebidas quanto mais se tornam habituais, também simulamos e dissimulamos com nós mesmos, duplicando-nos e muitas vezes até nos multiplicando" PIRANDELLO, Luigi. L'umorismo, op. cit. pp. 91-92.
} 
com os outros homens, onde pode gozar de um "momento di silenzio interiore", ${ }^{76}$ quando a alma, despida de todas as suas máscaras habituais, permite que existência seja algo mais do que uma experiência árida e inquietante. Talvez este seja o mesmo lugar privilegiado por Leopardi com seus "spazi interminati" e "sovrumani silenzi e profondissima quiete", onde a alma pode escutar a si mesma e não mentir mais, redescobrindo assim sua autenticidade; onde talvez seja possível a reconstituição do Eu dilacerado pelas relações sociais e penúrias de uma época cheia de incertezas e arbitrariedades.

Parece sintomático também que o último romance do autor, Uno nessuno $e$ centomila, publicado em 1926, tenha tido um tempo de composição tão longo, já que foi iniciado em 1909. Neste romance, que narra a trajetória de Vitangelo Moscarda a partir do momento em que a esposa chama a atenção para seu nariz torto, acompanhamos o protagonista em busca de sua verdadeira identidade, discutindo o sistema social de sua época e as máscaras que a sociedade lhe impõe. A cidade, assim, com sua rede de relações, parece ser a causa do mal que afeta Moscarda, que ao final, dado como louco, procura reconstituir sua identidade dissolvendo-se na natureza:

Nessun nome. Nessun ricordo oggi del nome di jeri; del nome d'oggi, domani.[...] E non sa di nomi la vita. Quest'albero, respiro trèmulo di foglie nuove. Sono quest'albero. Albero, nuvola; domani libro o vento: Il libro che leggo, il vento che bevo. [...] La città è lontana. [...] muojo ogni attimo io, e rinasco nuovo e senza ricordi: vivo e intero, non più in me, ma in ogni cosa fuori. ${ }^{77}$

\footnotetext{
${ }^{76}$ PIRANDELLO, Luigi. L'umorismo. Op. cit., p 93.

77 "Nenhum nome. Nenhuma recordação, hoje, do nome de ontem; do nome de hoje, amanhã. [...] E a vida não conhece nomes. [...] Esta árvore, respiro trêmulo de folhas novas. Eu sou esta àrvore. Àrvore, nuvem: amanhã livro ou vento. O livro que leio, o vento que bebo. [...] A cidade está distante. [...] Morro a cada instante, e renasço novo e sem recordações: vivo e inteiro, não mais em mim, mas em todas as coisas fora." PIRANDELLO, Luigi. Uno, nessuno e centomila. Milano: Mondadori, 1949, pp. 755-757.
} 
Talvez o tempo levado por Pirandello para desenvolver o romance tenha sido o tempo da maturação em busca de uma solução. O tempo de escrita do romance corresponde quase que integralmente à sua segunda fase - à procura de uma explicação -, fase esta em que escreveu a maior parte de suas novelas. Os primeiros capítulos do romance contemplam e retratam todas as idéias de Pirandello sobre o humorismo, que provavelmente os escreveu à medida que desenvolvia suas indagações. O último capítulo, no entanto, traz um fato novo em sua poética: a redenção. A reconstituição do Eu agora conjugado com a natureza. Até este momento o personagem pirandelliano, num rápido momento de iluminação causado por um fato corriqueiro, vislumbrava a verdadeira vida, aquilo que ele realmente era e como eram, juntamente com ele, todos os homens, tomando consciência do que poderia ser se pudesse ficar suspenso naquele instante efêmero. Mas a epifania levava a um estado de suspensão da realidade que durava apenas um instante, depois não restava nada mais senão recompor a máscara e retornar à "pena di vivere", resignadamente ou não, como alguém que tivesse visto momentaneamente o paraíso e depois tivesse de voltar ao inferno cotidiano.

Vitangelo Moscarda é o primeiro personagem de Pirandello a escapar desta armadilha. A natureza parece ser a solução para os problemas do homem e as incertezas do século que já havia concluído seu primeiro quarto. A conclusão de muitas das últimas novelas é semelhante à do romance: não mais se rebelar, não mais se debater. A luta apaixonada, ridícula, e por isso mesmo humorística, contra as imposições da vida social deve terminar, já que se demonstrou inútil; é preciso se resignar à solidão como única possibilidade de viver. 
Nas últimas novelas, o contraste entre cidade e campo torna-se tanto mais insistente quanto mais cresce em Pirandello o pessimismo. Quanto mais Pirandello adquire consciência do sentido trágico da vida, mais a cidade aparece como a causadora de todos os males, enquanto a natureza, em contrapartida, ganha um fascínio cada vez maior com a promessa de uma paz consoladora. Por isso, nessas novelas, a cidade ganha dimensões cada vez maiores. Em muitas delas não figura mais a Roma dos anos anteriores, mas as vertiginosas cidades americanas:

Parrà strano, ma anche in America c'è chi crede che le tartarughe portino fortuna. [...] Pur abituato com'è alla vista fantasmagorica di quella sua enorme città, ha sempre occhi nuovi per lasciarsene stupire e anche immalinconire un po', se pensa che a tutte quelle prodigiose costruzioni è negato di imporsi come durevoli monumenti e stan lì come colossali e provvisorie apparenze di un'immensa fiera, con quegl'immobili sprazzi di variopinte luminarie che danno a lungo andare una tristezza infinita, e tant'altre cose ugualmente precarie e mutevoli. ${ }^{78}$

É certo que a cidade americana correspondia a uma experiência do autor. De fato, suas peças estavam sendo representadas em Nova Iorque. Henry Ford o financiava e Greta Garbo havia sido a protagonista do filme As you desire me, baseado na peça Come tu mi vuoi (1930). A América encantava o mundo como símbolo do progresso e da liberdade. Mas nas novelas, a cidade não aparece como símbolo de progresso e liberdade, como para muitos de seus contemporâneos, ela surge como o lugar das multidões, onde as

\footnotetext{
78 “Pode parecer estranho, mas até na América há quem acredite que as tartarugas tragam sorte. [...] Mesmo habituado como está à visão fantasmagórica daquela sua enorme cidade, tem sempre novos olhos para se deixar espantar e também entristecer um pouco, se pensa que a todas aquelas prodigiosas construções é negado impor-se com monumentos duráveis, e estão ali com colossais e provisórias aparências de uma imensa feira, com aqueles jatos imóveis de luminárias coloridas que dão, ao percorrê-las, uma tristeza infinita, e tantas outras coisas igualmente precárias e mutáveis.” PIRANDELLO, Luigi. La tartaruga. In: Novelle per un anno. Op. cit., p. 750.
} 
possibilidades de contato humano são muito maiores e, portanto, ainda maior a possibilidade de violência e sofrimento.

Os momentos de epifania, agora muito mais frequientes e seus efeitos mais duradouros, em geral estão ligados a lembranças ou experiências relativas à vida campestre, quando no âmago de seu sofrimento o homem (re)descobre a natureza e se encanta. Esses momentos, que De Castris definiu como vontade de evasão, devem-se muito mais, em Pirandello, à tentativa de superação do pessimismo, como nos dias passados com os pais no campo que o rapaz assassino, de "Il chiodo"(1936, UG), relembra, ou no silêncio sem fim da noite em que o velho refugiado no campo, de "Vittoria delle formiche" (1936, UG), aplaca suas angústias, ou na noite campestre em que Cinci, de "Cinci" (1932, BG), perde consciência de si e das coisas, ou ainda na cintilante pureza dos astros, vistos da ponte sobre o rio, enquanto o tempo e as coisas permanecem suspensos num espanto atônito em "Un'idea" (1934, BG). São epifanias calculadas e provocadas pelos personagens, e não efêmeras consolações causadas por um incidente qualquer. São momentos de extrema doçura, em que o personagem se vê por inteiro e sabe que, conquanto esteja só, pode reevocá-los a qualquer instante. Não é a mesma coisa que a fuga de Belluca, em "Il treno ha fischiato" (1914, US), para um mundo de sonhos, ou o espanto de Ciàula diante da lua - "Ciàula scopre la luna" (1912, NC)). Agora, os momentos ganham a dimensão de eternidade. Pode-se viver neles; pode-se alcançá-los sem o obscurecimento piedoso da razão - e talvez até seja possível atingir "outra" ordem das coisas.

Outro tema recorrente nas últimas novelas, e estreitamente ligado aos anteriores, é a morte. Se a vida é mentira e há obrigatoriedade da máscara, é natural que cause dor. Devemos então lançar mão de todos os meios possíveis para nos livrarmos da "pena di vivere", seja a epifania efêmera de um outro mundo sonhado, mas proibido, ou a tentativa 
de escapar do fluxo contínuo da vida e vê-la passar, observando, sem viver, aqueles que vivem, ou então a loucura, voluntária ou real, ou, por fim, a morte.

Se a obra de Pirandello é uma meticulosa e apaixonada resenha de casos, numerosos e estranhos, em que o homem percebe a máscara, sente seu peso e faz um esforço para arrancá-la e recuperar seu verdadeiro rosto, então é natural que o pensamento da morte, ou sua aproximação, ou o medo que causa, façam parte dessa tomada de consciência. Assim, o tema da morte, que sempre fora até então recorrente nas novelas, torna-se quase uma obsessão nos últimos escritos. Os motivos são muitos e decorrem não apenas do que seria a evolução natural da obra do escritor. Devemos lembrar que Pirandello já havia passado dos sessenta anos. Havia chegado à idade em que começamos a nos familiarizar com a imagem da morte, com o momento em que os amigos começam a desaparecer; a hora em que, em nossas fantasias e meditações, fazemos um balanço e procuramos concluir projetos, como uma maneira de exorcizá-la e bani-la, à medida que nos preparamos para sua chegada.

Além disso, o mundo, na Itália e na Europa, havia se tornado mais triste e deprimente. As ditaduras pesavam, ainda mais na Itália, onde o fascismo havia se tornado a grande máscara de todos os italianos. Não que Pirandello devesse agora se tornar "antifascista", o que estava fora da lógica de seu pensamento, mas a máscara do fascismo era pesada e evidente demais: uniformes e divisas, camisas negras, inventar descendências, conquistar, sujeitar, cobrir o silêncio da natureza com o barulho da política. O fascismo impunha máscara sobre máscara e Pirandello devia sentir-se sufocar. Por outro lado, a tão sonhada fama havia chegado obrigando-o a atender às expectativas do público, da crítica e da academia. Os deveres eram tantos que o enrijeciam numa forma: uma forma imposta externamente pela história, que tentava criar certezas, e uma forma interna, que ele mesmo 
havia criado, não permitiam mais que ele vivesse - se é que viveu alguma vez - de acordo com suas leis e seus desejos.

Dessa maneira, a cidade se faz cada vez mais opressora, a natureza cada vez mais atraente; a remota infância na Sicília (como metáfora de campo) parece o paraíso perdido; a “corda pazza"de Ciampa ${ }^{79}$ dispara, e ele, se na vida social se comporta de acordo com a(s) máscara (s), se desafoga na arte tentando, talvez, a própria reconstituição. Pirandello sonha romper a seriedade fúnebre de uma festa, em que a maioria dos convidados não sabe o que está fazendo ali, com o som das risadas escandalosas e sem motivo de um camponês e seus dois filhos - "C"è qualcuno che ride" (1936, UG) -, destruir os habitantes de toda uma cidade apenas soprando sobre eles - "Soffio" (1931, BG) -, trazer uma vaga intenção de suicídio em uma noite límpida e cheia de estrelas - "Un'idea" (1934, BG), colocar-se na pele de um velho cavalo abandonado que "Non pensa a nulla. Nemmeno d'esser libero. Né dove o come andrà a finire. Nulla. [...] La sera è mite. Il cielo è stellato. Domani sarà quel che sarà." ${ }^{80}$ : exatamente o contrário de ser a pessoa importante que ele era naquele momento.

Pirandello, certamente, teve como meta um experimentar contínuo. Alguns temas, algumas soluções, já apareciam “in nuce” em seus primeiros escritos e foram desenvolvidos aos poucos na medida da evolução interna de sua visão de mundo, em consonância com tudo que acontecia ao redor dele na vida e na arte. Dono de uma obra extremamente auto-referencial, como já dissemos, ele se aprofunda nos temas que lhe são

\footnotetext{
${ }^{79}$ Personagem principal da peça Il berretto a sonagli (1917) que desenvolveu a teoria de que todos nós temos uma "corda pazza", uma "corda séria" e uma "corda civile" e as apertamos ou soltamos, como uma corda de relógio, à medida que necessitamos.

80 "Não pensa em nada. Nem ao menos em ser livre. Nem onde ou como irá acabar. Nada. [...] A noite é suave. O céu estrelado. Amanhã será o que tiver de ser." Pirandello, Luigi. Fortuna di essere cavallo. In: Novelle per un anno. Op. cit., p 759.
} 
caros, modifica e ajusta suas soluções formais, reapresenta com novos tons motivos antigos, dá uma nova veste às soluções de sempre.

\subsection{Língua e estilo}

Muito mais por uma necessidade da narrativa, da organização e transmissão de idéias, essas novelas apresentam um entrecho bastante reduzido, com poucos acontecimentos, sempre privilegiando a caracterização do sentimento do personagem às peripécias do enredo. Na maioria das vezes é possível reduzir a ação a um ou dois acontecimentos narrados rapidamente, mas cruciais para a história do personagem, sobre os quais ele reflete longamente. Os diálogos se rarefazem, transformados em longos monólogos em que a linguagem é poética e onírica, mais em sintonia com a interioridade do personagem. Nas palavras de Petronio:

[...] nessas últimas novelas "surrealistas" o discurso de Pirandello se faz, se não me engano, menos encorpado e violento, os interiores menos kitsch, os retratos menos inclementes, exceto onde [...] seja necessário criar o contraste. $^{81}$

Em muitas dessas novelas há também uma espécie de identificação do narrador com o personagem. Sobretudo nos momentos de maior introspecção do personagem, ambos se unem numa só voz narrativa, passando o narrador a "palavra" ao personagem num ato contínuo de narração para que este possa exprimir diretamente seus pensamentos e angus-

${ }^{81}$ PETRONIO Giuseppe. Op. Cit. Pág. 225-226 
tias. Essas novelas, todas narradas em terceira pessoa, momentaneamente dão um mergulho no íntimo do personagem para que ele mesmo possa expor diretamente sua "pena di vivere", indo buscar em seu âmago o "sentimento do contrário", sem a necessidade de uma "percepção do contrário". Este é um procedimento novo em Pirandello que nas novelas anteriores separava nitidamente as vozes do narrador e do personagem. Isto ocorre apenas nessas novelas, embora não em todas, e tem o sentido contrário ao preconizado em L’umorismo. Não é mais preciso a cena ridícula, risível ou humilhante, que pela reflexão leve à constatação do sofrimento do personagem, pois neste momento a constatação já é patente, o autor busca a solução, a realidade "outra" e, para isso, precisa escutar diretamente da alma de seu personagem, sem a intermediação das palavras, suas aspirações. São fragmentos da alma que anseiam pela unicidade, como se pode ilustrar com o trecho da novela "Il chiodo" (1936, UG), abaixo:

Narrador em $3^{\text {a }}$ pessoa

Con questo sentimento segreto, che lo cuoce, non gli importa se coloro che parlano offendono la verità, e dicono cose contro di lui; anzi n'è contento perché ogni cosa ingiusta che dicono gli dimostra sempre più che vera è invece soltanto quell'altra a cui nessuno vuol credere, di quel chiodo cioè caduto apposta e di Betty e dell'altra ragazza che, proprio mentre lui svoltava dalla strada, si erano azzuffate ugualmente apposta perché lui da quella loro zuffa trascinato a menar le mani, senza più pensarci armato di quel chiodo, commettesse la feroce ingiustizia d'uccidere una innocente. ${ }^{82}$

\footnotetext{
82 “Com esse sentimento secreto que o consome, não lhe importa se os que falam ofendem a verdade, e dizem coisas contra ele; ao contrário, fica contente porque cada coisa injusta que dizem a ele demonstra que a única verdade é aquela em que ninguém quer acreditar, que aquele prego caiu de propósito e que Betty e a outra menina que, justo quando ele virava a rua, se atracaram também de propósito, para que ele, atraído pela briga fosse forçado a agir, sem pensar que estava armado com o prego, e cometesse a feroz injustiça de matar uma inocente.” PIRANDELLO, Luigi. Il chiodo. In: Novelle per un anno. Op. cit., p 768.
} 


\section{Personagem em $1^{a}$ pessoa}

\section{Narrador em $3^{\text {a }}$ pessoa}

E non è vero, Betty, dei tuoi capelli; che i tuoi capelli rossi non erano belli. Erano belli, erano belli e ti stavano bene. E che importa che sul visino affilato abbia tutte quelle lentiggini? Se aprissi gli occhi che non t'ho nemmeno visti! Ah, fosse avvenuto il miracolo che tu, là per terra, fra tutto quel sangue, per far passare a tutti lo spavento, d'improvviso scoprissi la furbizia di due occhietti vispi. Ma non è avvenuto questo miracolo. Gli occhietti te li ho visti soltanto chiusi, per sempre. Forse, malatuccia, non potevi più averli vispi. Non importa, non importa: aprili, aprili, Betty, e sorridi. Forse ti manca qualche dentino; non li avrai ancora rimessi tutti; non importa, sorridi. Ma queste labbra bianche, queste labbra bianche; bisogna lavare subito tutto questo sangue. ${ }^{83}$

Insulto epilettico? Chi dice insulto epilettico?

Lo dicono per lui, e spiegano i sintomi del male. Ma lui è sicuro di non aver mai provato nulla di simile. Può darsi che sia affetto di quel male senza saperlo, rimasto nascosto fino al momento del delitto e tutt'a un tratto esploso in lui ${ }^{84}$

Essas observações levam à constatação de que, nessas novelas, e também nas peças consideradas "míticas", há uma mudança não tanto de ideologia quanto de tom psicológico, o que é bem diferente.

A obra de arte, com meios e técnicas diferentes, pode ser descrita como uma visão da vida que o autor, "animal social", absorve de um grupo social historicamente determinado, reelabora e organiza de acordo com uma perspectiva pessoal. Assim sendo,

\footnotetext{
83 "E não é verdade, Betty, que os seus cabelos, seus cabelos vermelhos, não fossem bonitos. Eram bonitos, eram bonitos, e ficavam bem em você. E que importa se o seu rostinho afilado tinha todas aquelas sardas? Se você abrisse esses olhos que eu nunca vi! Ah, se tivesse acontecido o milagre de você, lá no chão, no meio daquele sangue, para surpresa de todos, de repente mostrasse a esperteza de dois olhinhos vivos. Mas o milagre não aconteceu. Só vi seus olhinhos fechados, para sempre. Talvez, por ser doentinha, não os pudesse ter tão vivos. Não importa, não importa: abra-os, abra-os, Betty, e sorria. Talvez lhe faltem alguns dentinhos, talvez eles não tenham despontando todos, não importa, sorria. Mas estes lábios brancos, estes lábios brancos; é preciso lavar logo todo este sangue." Ibid., p. 768-69

84 "Surto epiléptico? Quem disse surto epiléptico? / Dizem a ele e explicam os sintomas do mal. Mas ele está certo de jamais ter sentido algo parecido. Será que ele tem a doença sem saber, e que esta ficou escondida até o momento do crime e de repente se manifestou?" Ibid., p.769.
} 
não é possível analisar uma obra de arte fazendo apenas análises técnicas ou história da cultura, mas é preciso também entender e buscar o tom particular com que aquele indivíduo, naquele momento de sua vida, organiza as idéias, as experiências que o rodeiam, vindas tanto de seu grupo social quanto de sua história privada, de sua memória cultural ou de suas experiências pessoais.

Ora, a partir do final dos anos 1920, muitas coisas mudaram na vida privada e afetiva de nosso escritor, muitas coisas mudaram no mundo, na arte e na cultura. Mas essas coisas parecem não ter modificado muitas das convicções de Pirandello. O mundo, para ele, é sempre o mesmo, uma natureza fascinante com homens inutilmente agitados; a vida é uma sufocante imposição de máscaras, das quais é preciso se libertar. As soluções são as de sempre: o refúgio na falsa loucura - "Il treno ha fischiato" (1914, US) -, a indiferença como meio de escapar a pressões - "Rimedio: la geografia" (1920, SN) - ou a fuga de tudo e de todos - "Fuga" (1923, NC).

Pirandello, no entanto, nota ao seu redor um clima novo, sente a necessidade de dizer coisas novas. $\mathrm{O}$ caminho traçado até aqui aponta para uma solução que talvez não seja mais representável da maneira que vinha sendo representada até então, se não no conteúdo, pelo menos no tom. Suas novelas que a princípio, como num teorema, levantavam hipóteses, testavam situações, não conseguem mais mostrar os resultados com os recursos que vinham sendo utilizados. É preciso achar novos tons, de estilo e de língua. Novos, mas não a ponto de revolucionar seus modos expressivos, novos apenas o suficiente para demonstrar o que é necessário. É para completar esta operação que Pirandello modifica e calibra não apenas a criação narrativa, mas também a língua e o estilo. 


\subsection{A dissolução da forma}

Embora o número das novelas da última fase seja pequeno se comparado à produção anterior, é possível verificar como Pirandello aplica suas novas idéias à literatura. Juntamente com as três peças míticas, Lazzaro, La nuova colonia e a inacabada I giganti della montagna, elas formam o testamento do autor que depois de uma vida dedicada ao estudo do sofrimento humano, denunciando suas causas, procurando explicações, tecendo hipóteses, parece ter chegado a uma solução. Esta solução passa por uma relação mais próxima com a natureza e pelo distanciamento da sociedade. A morte pode ser agente e não fim; o tempo pode ser suspenso em momentos de epifania que levam a estados de bemestar duradouros; um recomeço é possível em uma realidade "outra".

Assim, em "Visita" (1935, UG), ${ }^{85}$ a terceira novela do volume Una giornata das Novelle per un anno, o passado retorna como uma perturbadora alucinação para acertar contas com o presente. A novela se inicia com um breve diálogo, que mais parece uma pequena cena teatral, entre o narrador e seu mordomo, que vem anunciar a visita da Sra. Anna Wheil. O narrador, que nunca é nomeado, sabe por uma nota de jornal, que Anna Wheil morrera um dia antes em Florença. Entre parêntesis, no texto, o homem afirma que talvez nunca tenha tido aquela conversa com o mordomo, que talvez tenha sido um sonho provocado pela nota do jornal, e que se lembra bem de ter sonhado com Anna Wheil castamente "avvolta in una nuvola bianca di primavera che s'andava man mano si diradando fino a lasciar trasparire la rosea nudità di tutto il corpo di lei”. ${ }^{86}$ Desde o início fica claro que Anna Wheil é o objeto de desejo do narrador, que consegue satisfazê-lo

\footnotetext{
${ }^{85}$ PIRANDELLO, Luigi. Visita. In: Novelle per un anno. Op. cit., pp. 696-701.

86 "envolta em uma nuvem branca de primavera que aos poucos ia se desmanchando até deixar transparecer a rósea nudez de todo seu corpo” Ibid., p. 696.
} 
apenas em sonho. A partir deste momento instaura-se um clima onírico, irreal e atemporal. Quando o narrador vê sua hóspede "vestita d'un bianco abito estivo d'organdis", ${ }^{87}$ sentada em seu estúdio decorado em tons de verde e azul e praticamente imerso no verde do jardim, ou seja, em uma atmosfera irreal e diáfana que recria e absorve a natureza, descobre porque sonhou com ela envolta em uma nuvem: é como se ela vestisse o mesmo vestido branco de verão com o qual a conheceu em um garden-party, três anos antes.

O clima de fantasia criado pela descrição das cores que penetram no ambiente do estúdio traz um conjunto de sensações ideais ligadas à natureza, e ao local onde se deu o primeiro encontro dos dois (o garden-party) extingue qualquer temporalidade e funde o passado no presente. Esta fusão, que o narrador denomina "eterno presente", ${ }^{88}$ acontece através de um jogo de tempos verbais no qual se alternam o presente do indicativo (Apenas a conheço) e o pretérito imperfeito (Apenas a conhecia), o que introduz a cena em que os protagonistas se conheceram durante o garden-party e procura reproduzir o encantamento daquela tarde de primavera.

La conosco appena (morta, dovrei dire: "la conoscevo appena", ma lei è qua ora come nell'assoluto d'un eterno presente, e posso dir dunque: la conosco appena), l'ho veduta una volta sola in una riunione festiva nel giardino d'una villa di comuni amici, a cui lei è venuta con quest'abito bianco d'organdis. ${ }^{89}$

O jardim onde se realiza a festa é descrito como o paraíso terrestre, um locus amoenus onde o narrador se compara ao primeiro homem e Anna à primeira mulher, objeto de

\footnotetext{
87 "vestida com um vestido branco de verão, de organdi" Ibid., p. 697.

${ }^{88}$ Ibid., p. 698.

89 "Mal a conheço (morta, eu deveria dizer: "mal a conhecia", mas agora ela está aqui como no absoluto de um eterno presente, e assim posso dizer: mal a conheço); a encontrei apenas uma vez em uma reunião festiva no jardim de uma casa de amigos comuns, à qual ela compareceu com esse vestido branco de organdi”. Ibid., p. 698.
} 
adoração que não pode ser tocado. Ao ser apresentado a Anna, ela está (estava) inclinada, arrumando os cabelos de algumas crianças com quem brincava momentos antes e, ao se levantar, o amplo decote do vestido se abre mostrando seus seios: “... sicché io non potei fare a meno d'intravedere del suo seno forse più di quanto onestamente avrei dovuto." 90

Uma comunicação intensa e silenciosa inicia-se através de olhares e os enlaça pela "eternidade". A linguagem com que o narrador descreve a cena, de devoção religiosa, mas refinadamente erótica, remete àquela que os poetas do dolce stilnovo utilizavam para louvar suas amadas. Anna é comparável à donna angelicata dos sonetos e canções de Dante e Petrarca, uma Laura ou Beatriz atualizada. Uma mulher que nenhum homem, exceto o narrador, poderá compreender e amar completamente. Seus seios, apesar da ousadia, são como visões do paraíso que consolam o amado de todos os sofrimentos terrestres.

A atmosfera da novela desenvolve-se, a partir daí, em duas dimensões difusas, uma real e outra onírica. Anna continua sendo a dama da sociedade que tem um marido e o narrador compreende que deveria ser vinte anos mais novo para conseguir separá-la dele. Ao mesmo tempo, a distância respeitosa que os separa assemelha-se ao distanciamento que os poetas medievais tinham da amada à qual entregavam seu afeto e devoção, que em geral era uma mulher casada.

Libertando-se de seu devaneio, o narrador nota que Anna está ali a seu lado e fala com ele familiarmente, como se passado e presente estivessem completamente fundidos, fazendo com que a conversa da festa se prolongue naturalmente no estúdio:

- Se dovessimo pensare a te e a me...

Mi voltai. Come! Mi dava del tu ?1 $^{11}$

\footnotetext{
90 “... de modo que não pude deixar de entrever de seu seio, mais do que honestamente deveria ver.” Ibid., p. 699.

91 “- Se tivéssemos que pensar em você e em mim... / Me virei. Como! Ela me tratava por você?” Ibid., p. 701.
} 
O estúdio, na luz esverdeada filtrada pelas árvores do jardim, está como que mesclado no jardim do devaneio e parece envolvido pela mesma atmosfera mágica da festa, que dá um tom harmonioso de esperança a todas as coisas. Tudo parece perfeito: a natureza tem o poder de tudo amenizar. Mas Anna lhe descreve como o câncer a atacou, nos seios, os mesmos seios que ele havia admirado por um instante na festa, e que foram a causa de sua morte:

- Il mio seno, se sapessi! Ne sono morta. Me lo hanno reciso. Un male atroce ne fece scempio due volte. La prima, un anno appena dopo che tu, di qua, ricordi? me lo intravedesti. Ora posso allargare con tutt'e due le mani la scollatura e mostrartelo tutto, com'era, guardalo! guardalo! ora che non sono più. ${ }^{92}$

De repente, o eterno presente se desfaz, e olhando para o sofá, o narrador vê apenas "il bianco del giornale aperto" "93: Anna Wheil desapareceu.

Toda a novela é estruturada na dicotomia eternidade/momento, até o "eterno presente" traz consigo um sentido de urgência e lentidão, o instante que se dissolve na atemporalidade, a vida que passa sem pressa em um minuto. A identidade objetiva do narrador, nunca revelada, faz com que ele seja um homem qualquer que pode transcender o tempo, uma vez que não tem nome, e assim, pode representar todos os homens de todos os tempos, sem solução de continuidade. Por outro lado, o nome da protagonista, Anna Wheil, é formado por dois vocábulos curtos, pequenos, e o segundo tem quase a mesma pronúncia da palavra "Weile", que em alemão, língua que Pirandello conhecia bem, significa “instante", “momento".

\footnotetext{
92 “- Os meus seios, se você soubesse! Morri por causa deles. Eles os tiraram. Um mal atroz os atacou duas vezes. A primeira, apenas um ano depois que você, aqui - lembra-se? - os viu. Agora posso abrir com as duas mãos o decote e mostrá-los inteiros, como eram. Olhe! Olhe agora que não existo mais!" Ibidem.

93 "o branco do jornal aberto". Ibid., p. 701.
} 
Sem tentar uma interpretação freudiana (alguns críticos associam os seios de Anna à imagem da mãe e o câncer é interpretado como a proibição do incesto),${ }^{94}$ podemos dizer que o câncer que matou Anna Wheil é uma espécie de "visita", a visita da morte, o momento no qual o personagem fica entregue a si mesmo em um agudo estado de consciência; no qual a beleza angelical da morta, gravada no inconsciente do narrador, pode ser convocada a qualquer instante como uma experiência erótica transitória de desintegração. A atmosfera onírica, quase surreal, reconduz ao momento de lucidez interior do protagonista, que ao ler sobre a morte no jornal, sente-se culpado por haver conspurcado com o olhar aquela mulher idealizada, casada com outro homem, que nunca poderia nem deveria lhe pertencer - la donna angelicata. Essa atmosfera, no entanto, só é possível com a mediação da natureza - o estúdio verde e azul no meio do jardim liga-se diretamente ao garden-party. A tragicidade consiste em ter sido ele, involuntariamente, o causador da morte; inconscientemente ele conhece a dimensão de seu desejo e o quanto aquele encontro afetou sua vida, tornando-se o ponto culminante de sua existência. O obituário do jornal é o agente que provoca um momento de alienação, uma inversão na ordem lógica das coisas que invade a consciência e produz um estado de sonho anulando a percepção de tempo e espaço. A máscara das relações sociais, depois da morte de Anna Wheil, não pode e nem deve ser mantida; agora ele pode (poderia) olhar calmamente o objeto de seu desejo, e o estúdio do jardim é o local ideal para essa suspensão temporal, pois é capaz, através da natureza, de ligar presente e passado em um amálgama indistinto de sensações. O narrador, apesar da morte da amada, sente-se completo em suas recordações, como já acontecera na festa do jardim:

\footnotetext{
${ }^{94}$ TERRACINI, Benvenuto. Le novelle per un anno di Luigi Pirandello. In: Analisi Stilistica. Op. cit.
} 
[...] una cosa bella, da riempirci della più pura gioja tra tanto splendore di sole e tanto riso di primavera, s'era rivelata a noi: questa cosa essenziale che è sulla terra, con tutto il nudo candore delle sue carni, in mezzo al verde d'un paradiso terrestre, il corpo della donna, concesso da Dio all'uomo come premio supremo di tutte le sue pene, di tutte le sue ansie, di tutte le sue fatiche..$^{95}$

Ainda no volume Una giornata, encontramos as novelas, escritas em 1934, "Fortuna d'esser cavallo" (décima primeira novela) e "C'è qualcuno che ride" (segunda novela). Na primeira, o tema da morte representada em um cavalo velho e doente, abandonado por seu dono (como velho e doente estava Pirandello, abandonado por Marta Abba?), porque não pode mais trabalhar: "Um cavallo che non può servire più a nulla, per dir la verità" ${ }^{96}$ Depois de esperar inutilmente diante do antigo estábulo, é cercado por curiosos que especulam sobre os motivos pelos quais o dono o deixara ali e se mudara para outra cidade:

Non mangiasse, un cavallo, ma mangia. E per il servizio che quello può ancora rendere così vecchio e malandato, siamo giusti, vi par che valga la spesa del fieno o anche di un po' di paglia da dargli a mangiare? ${ }^{97}$

O cavalo, então, vaga pela cidade à procura de comida, cercado por meninos que o maltratam e por adultos que o enxotam. Toda a cidade participa da desventura do animal: crianças, adultos, comerciantes, policiais. Nem um gesto de compaixão, nenhuma atitude positiva. Ser velho e doente na sociedade é um mal que precisa ser afastado, não deve ficar

\footnotetext{
95 “[...] uma coisa bonita, que nos preenchia da mais pura alegria entre tanto esplendor de sol e tanto riso de primavera, nos havia sido revelada: essa coisa essencial que há na terra, com toda a nua ingenuidade de suas carnes, em meio ao verde de um paraíso terrestre, o corpo da mulher, concedido por Deus ao homem como recompensa suprema de todas suas penas, de todos seus desejos, de todos seus cansaços. Op. cit., p. 701.

96 "Um cavalo que não pode mais servir para nada, para dizer a verdade.” PIRANDELLO, Luigi. La fortuna d'esser cavallo. In: Novelle per un anno. Op. cit., p. 753

97 "Se um cavalo não comesse, mas come. E pelo serviço que ainda pode fazer, assim velho e doente, sejamos justos, será que vale a pena a despesa do feno ou mesmo um pouco de palha para dar-lhe de comer?" Ibid., p.754.
} 
exposto à vista de todos. A sociedade é cruel e não está disposta a refletir sobre seus próprios males:

Ma non commoviamoci. Non dimentichiamo la fortuna che ha quel cavallo, come ogni altro: la fortuna d'esser cavallo. ${ }^{98}$

Finalmente, o cavalo sai da cidade sob os aplausos, risos e assobios de seus habitantes. O contato com a natureza, mais uma vez, é a solução. Para um animal repentinamente livre, a única coisa que importa é a sobrevivência:

Perché tra le tante disgrazie che gli possono occorrere, capitando sotto gli uomini, un cavallo ha almeno sempre questa fortuna: che non pensa a nulla. Nemmeno d'esser libero. Né dove o come andrà a finire. Nulla. Lo cacceranno da per tutto? Lo butteranno a sfragellarsi in un burrone?

Ora, per il momento, mangia l'erba della proda. La sera è mite. Il cielo è stellato. Domani sarà quel che sarà.

Non ci pensa. ${ }^{99}$

Mas ao homem não toca a mesma sorte, ele pensa. E não quer ser recompensado por uma vida de trabalhos com uma morte miserável, na indiferença e na solidão. O único refúgio está na estratégia do cavalo: não pensar em nada, abolir o tempo, voltar à natureza benéfica de onde nunca deveria ter saído. A diferença com a análoga condição humana consiste no fato de o cavalo morrer pacificado. Não sabe e não pensa na morte. O homem, nos adverte Pirandello, não consegue se libertar do pensamento do fim de sua dolente aventura terrena; está condenado a

\footnotetext{
${ }^{98}$ Mas não nos comovamos. Não esqueçamos a sorte que tem este cavalo, como qualquer outro: a sorte de ser cavalo. P. 758.

${ }^{99}$ Porque entre as muitas desgraças que lhe podem acontecer, estando entre os homens, um cavalo tem pelo menos esta sorte: não pensa em nada. Nem ao menos em ser livre. Nem onde e como irá acabar. Nada. Será sempre enxotado? Será atirado em um precipício? / Ora, no momento ele come o capim da beira da estrada. A noite é suave. O céu estrelado. Amanhã será o que tiver de ser. Não pensa nisso. Ibid., p. 759.
} 
contar até as últimas palpitações da vida, ou, como já afirmara "o homem com a flor na boca": "sentiamo tutti come un'angoscia nella gola". 100

Em “C'è qualcuno che ride" (1934, BG) encontramos, como escreveu Guglielmi,

[...] um pouco de toda a fenomenologia do riso: a afinidade entre riso e terror, o riso social e até ritual, o riso, enfim, como alheamento do social, puro fenômeno mimético-vital (correspondente ao que em sua Essence du rise, Baudelaire teria chamado de joie, atribuindo-lhe a condição de inacessível e para sempre perdida). ${ }^{101}$

Em uma cidade não identificada, uma proclamação oficial convida toda a população a participar de uma festa. Ninguém sabe o motivo do convite, nem ousa perguntar aos outros para não dar a entender ser o único a ignorá-lo. De tempos em tempos, alguém é convidado a entrar em um quarto secreto onde se supõe que uma grave decisão está sendo tomada. Enquanto esperam uma proclamação qualquer, os convidados parecem ter um acordo tácito de manter um grave decoro, o que parece ser o mais adequado para as circunstâncias. É uma situação paradoxal e grotesca: “un’orchestrina di calvi inteschiati che suona senza fine ballabili, e coppie ballano per dare alla riunione un'apparenza di festa da ballo, all'invito e quasi al comando di fotografi chiamati apposta", ${ }^{102}$ mulheres elegantemente mal vestidas, olhares desconfiados, homens carrancudos por não saberem o que está acontecendo.

\footnotetext{
100 "Todos nós sentimos como que uma angústia na garganta". PIRANDELLO, Luigi. La morte adosso. In: Novelle per un anno. Op. cit., p 40.

${ }^{101}$ GUGLIELMI, Guido. La prosa italiana del novecento: umorismo, metafisica grottesco. Torino, Einaudi, 1986, p. 143.

102 "uma orquestrinha de carecas cadavéricos, que toca sem parar música de dança, e pares que dançam para dar à reunião uma aparência de baile, ao convite e quase comando de fotógrafos chamados para a ocasião”. P. 689.
} 
Toda a novela não é a narração de alguma coisa, mas da remoção de alguma coisa [...]. É uma situação compulsória e angustiante, mas também insensata e cômica (...). E, no entanto, exatamente o riso è um escândalo inadmissível. $^{103}$

A atmosfera claustrofóbica, realçada pelo escurecido afresco do século XVII que ocupa toda a volta do teto, pode ser entendida como uma sátira política do espírito de conformismo que caracterizava a vida na Itália sob o regime fascista, ou mais além, sob os regimes totalitários em geral. De repente:

Serpeggia una voce in mezzo alla riunione.

- C'è qualcuno che ride. ${ }^{104}$

Toda a falsa solidariedade da multidão - baseada no medo e na ignorância - é desafiada por três pessoas que quebram as regras rindo alegremente em meio à reunião. Quem seriam?

Nessuno li conosce. Nemmeno io. Ma so che è lui il padre di quei due ragazzi, signore agiato che vive in campagna con la figlia, mentre il figlio è agli studii qua in città. ${ }^{105}$

Os espelhos da sala refletem a paranóia da multidão acossada pelo riso espontâneo e cristalino daquela pequena família. O espelho, figura recorrente de toda a obra de Pirandello, passa a refletir não mais a angústia do personagem, mas toda a sociedade com seus males e suas máscaras.

103 "GUGLIELMI, Guido. La prosa italiana del novecento: umorismo, metafisica grottesco. Op. cit., p. 146.

104 “Uma voz sibila em meio à reunião. / - Alguém está rindo". PIRANDELLO, Luigi. C'è qualcuno che ride. In: Novelle per un anno. Op. cit., p 689.

105 "Ninguém os conhece. Nem eu. Mas sei que ele é o pai daqueles dois jovens, um senhor de posses que mora no campo com a filha, enquanto o filho estuda aqui na cidade.” Ibid., p. 693. 
Para punir os três por sua rebeldia, a multidão os cerca e com movimentos perfeitamente uniformes, como que robotizados, os acua em um sofá, sempre avançando sobre eles. Da sala secreta saem três figuras encapuzadas, trazendo nas mãos guardanapos para amordaçá-los e se dirigem para o sofá.

Appena sono davanti al divano, una enorme sardonica risata di tutta la folla degli invitati scoppia fracassante e rimbomba orribile più volte nella sala. Quel povero padre [...] riesce a prendersi sotto braccio i due figli e [...] se ne scappa, inseguito dal terrore che tutti gli abitanti della città siano improvvisamente impazziti. ${ }^{106}$

O riso sardônico, escarnecedor e provocador, exorciza a leviandade e a transgride a realidade, buscando restabelecer as convenções.

Toda a novela está estruturada em uma série de repetições e imagens que indicam um pesadelo. O pesadelo fascista ou o pesadelo social que impõe máscaras e comportamentos. Aqueles que não se adaptam são banidos da sociedade, como eram confinados os dissidentes na era fascista, e os três camponeses tiveram a suprema ousadia de se divertir na recepção sem temer as conseqüências dessa conduta, que poderia parecer normal para eles, mas que para a maioria era um desrespeito evidente. Para Bergson, o riso "assinala, no exterior da vida social, as revoltas da superfície", ${ }^{107}$ e a risada final transforma a rigidez robótica da multidão em plasticidade, mas também reprime qualquer tendência à separação. Sob regimes ditatoriais, o normal se torna anormal e suspeito; o ato mais natural, como o riso, pode ser interpretado como

\footnotetext{
106 "Assim que chegam ao sofá, uma enorme e sardônica risada de toda a multidão de convidados estoura ruidosamente e ecoa horrivelmente várias vezes pelo salão. Aquele pobre pai [...] consegue pegar os dois filhos pelo braço e [...] foge, perseguido pelo terror que todos os habitantes da cidade tenham enlouquecido de repente.", Ibid., p. 695.

${ }^{107}$ BERGSON, Henry. O riso. Ensaio sobre a significação do cômico. Rio de Janeiro, Zahar Editores, 1983, p. 101.
} 
um desafio à política oficial. A sociedade é implacável, não pode permitir a dissidência; o totalitarismo é mais implacável ainda.

Mais uma vez a oposição cidade/campo aparece nas últimas novelas. A espontaneidade e a alegria, que só eram permitidas ao homem não fragmentado, são representadas pela família vinda do campo, em contraposição à seriedade e sofrimento da população da cidade que está reunida no salão sem saber por quê. As máscaras sociais assumidas pela multidão só trazem medo e angústia, e são como que abençoadas pelo grande afresco setecentista que circunda o salão. O viver social está condicionado à "pena di vivere”, o viver natural dá ao homem, em sua integração na natureza, a possibilidade de se reconstituir espiritualmente.

L'ossessione di questa serietà è così su tutti incombente e soffocante, che nessuno riesce a supporre che quei tre ne possano esser fuori, lontani, e possano avere in sé invece una innocente e magari sciocca ragione di ridere così di nulla; la ragazza, per esempio, solo perché ha sedici anni e perché è abituata a vivere come una puledra in mezzo a un prato fiorito, una puledra che imbizzarrisca a ogni alito d'aria e salti e corra felice. ${ }^{108}$

Na novela "Di sera, un geranio" (1934, BG), ${ }^{109}$ a última do volume Berecche e la guerra, e talvez a mais lírica de toda a obra de Pirandello, a morte se torna um suave flutuar da consciência em direção ao nada. O tempo é completamente anulado, ou não interessa mais, transcendendo o sentido da narrativa para adquirir a mesma fluidez do espírito que, liberto do corpo, flutua em um ambiente familiar que pouco a pouco se distancia no espaço.

\footnotetext{
${ }^{108}$ A obsessão desta seriedade é tão ameaçadora e sufocante, que ninguém consegue supor que aqueles três possam estar de fora, distantes, e possam ter até uma razão inocente e talvez boba para rir assim à toa. A jovem, por exemplo, apenas porque tem dezesseis anos e está habituada a viver como uma potrinha no meio de um prado florido, uma potrinha que se agita a cada golpe de vento e salta e corre feliz. PIRANDELLO, Luigi. C'è qualcuno che ride. In: Novelle per un anno. Op. cit., pp. 693-694.

109 PIRANDELLO, Luigi. Di sera un geranio. In: Novelle per un anno. Op. cit., p. 678.
} 
Um homem está morrendo após ter sofrido uma operação. Para este homem, mais uma vez anônimo, a morte é perder o contato material com os objetos que lhe eram caros em vida. A confusão do espírito arrancado do corpo e transformado em consciência é representada pelos advérbios de lugar, que tentam reconstituir a posição original das coisas no quarto onde ocorreu a morte (qua, là, giù). Como em "Visita" (1936, UG), e em menor grau nas novelas acima analisadas, a ausência de tempo, ou o tempo amalgamado em um único momento, onde passado e presente se confundem, pode ser observada no uso dos tempos verbais, na alternância ente o uso do imperfeito e do presente: "Dormiva, e non è più nel suo corpo". ${ }^{110}$ Com este artifício, a voz do narrador e do protagonista fundem-se misturadas na inquietação causada por esta última visita. Do alto, o protagonista/narrador vê o corpo que lhe pertencera e não o reconhece mais; não pode reconhecer aquela forma estendida no leito e que não é mais o que fora em vida e nem o que é agora:

Lui non era quel suo corpo; c'era anzi così poco; era nella vita lui, nelle cose che pensava, che gli s'agitavano dentro, in tutto ciò che vedeva fuori senza vedere sé stesso. Case, strade, cielo. Tutto il mondo. ${ }^{111}$

O protagonista/narrador não é mais o personagem, procura "ver-se viver" e não consegue mais, está se desagregando, disseminando-se nas coisas materiais que uma vez lhe pertenceram e que não mais o representam. São, no máximo, a lembrança dele: o "orologio sul comodino, quadretto alla parete, lampada rosea sospesa in mezzo alla camera", ${ }^{112}$ que ficara acesa em vão. Aqui, a máscara também se dissolve, nem é preciso

\footnotetext{
110 “Dormia, e não está mais no seu corpo." Ibid., p. 677.

111 "Ele não era aquele seu corpo; aliás, havia muito pouco dele ali. Ele existia na vida, nas coisas que pensava, que se agitavam dentro dele, em tudo o que via fora, sem ver a si mesmo. Casas, ruas, céu, todo o mundo. Ibid., p. 676.

112 "o relógio no criado-mudo, o quadrinho torto na parede, a lâmpada rosa suspensa no meio do quarto" Ibid., p. 677 .
} 
arrancá-la: se o personagem não tem mais um papel a representar, se está sozinho na essência de seu ser, a máscara não faz mais sentido, nem para ele, nem para os outros que também não existem mais. Morrer é não-ser, é a dissolução de todas as formas, nas quais a vida costuma encontrar uma finalidade.

Mas se existe ainda uma possibilidade, por menor que seja, de continuar a viver sem "adotar uma forma", até a morte pode ser negada e esta poderia ser a solução, só aparentemente paradoxal, da dicotomia vida e forma, que está na tese identificada por Tilgher na obra de Pirandello. Na impossibilidade da forma, a vida não poderia existir, mas a morte também não. O personagem pirandelliano está sempre preso a uma forma que lhe transmite a dimensão humana e os objetos são sua medida e representação. Agora, nesse espaço suspenso entre a vida e a morte, o momento que se faz, mais uma vez, eternidade, a forma não é relevante, mas os objetos ainda têm uma estrutura formal que é negada ao espírito. O que é preciso é tentar resistir um pouco, fundir-se em uma forma qualquer para fazer parte da eternidade, mesmo que seja só por um instante:

Una cosa, consistere ancora in una cosa, che sia pur quasi niente, una pietra. $\mathrm{O}$ anche un fiore che duri poco: ecco, questo geranio... ${ }^{113}$

A flor, que na novela "La morte addosso" (1918, IS) ${ }^{114}$ também representava simbolicamente a morte, recebe aqui um significado mais amplo, representa um momento de extrema lucidez no qual o personagem toma consciência da sua verdadeira vida interior nos instantes que, algumas vezes, precedem a morte física, transformando-os em eternidade. A natureza que acolhe o espírito confere à fenomenologia da morte, mais do

\footnotetext{
113 "Uma coisa, ainda fazer parte de uma coisa, mesmo que seja um quase nada, uma pedra. Ou mesmo uma flor que dure pouco: aqui está, este gerânio..." Ibid., p. 679.

${ }^{114}$ PIRANDELLO, Luigi. La morte addosso. In: Novelle per un anno. Op.cit., vol. 1, tomo 2, pp. 39-41.
} 
que um simples momento de passagem para o nada, um vestígio de dignidade. É por isso que "Di sera, qualche volta, nei giardini s'accende così, improvvisamente, qualche fiore; e nessuno sa spiegarsene la ragione."115

A morte, no último Pirandello, não é mais o final da trajetória de um personagem angustiado que anseia por escapar da vida e da forma, mas de uma voz que representa e se confunde com o narrador em busca de eternidade, em uma tranqüila passagem para uma ordem "outra" das coisas em que ele possa se reconstruir. Não existem mais espelhos para se ver viver, os objetos materiais perdem significado e a máscara é definitivamente posta de lado. O sofrimento humano se dissolve na natureza juntamente com o personagem, e se torna até difícil, como afirmou Luperini, considerar que este morreu.

A descoberta de um inverossímil poder leva o protagonista de "Soffio" (1931, BG) ${ }^{116}$ terceira novela do volume Berecche e la guerra, para fora da vida cotidiana e o transforma em um terrível instrumento de morte, talvez na própria morte.

Um simples gesto, juntar o indicador e o polegar de uma das mãos para soprar sobre eles, em meio a uma conversa trivial, provoca a morte do secretário de um amigo e depois do próprio amigo. Não acreditando ser a causa destes acontecimentos, o homem experimenta repetidamente o gesto pelas ruas da cidade sempre com o mesmo resultado. Os jornais, no dia seguinte, noticiam novecentos e dezesseis mortes em uma noite só: é uma epidemia, dizem. Assustado, e temendo ter enlouquecido, o homem procura uma prova que demonstre a ausência de relação entre seu gesto e as mortes repentinas, procurando outras causas para a "epidemia". Evita repetir o gesto por quinze dias e a

\footnotetext{
115 “À noite, algumas vezes, nos jardins desabrocha, de repente, alguma flor; e ninguém sabe explicar a razão." PIRANDELLO, Luigi. Di sera, un geranio. In: Novelle per un anno. Op. cit., p. 679.

${ }^{116}$ PIRANDELLO, Luigi. Soffio.In: Novelle per un anno. Op. cit., pp. 631-647.
} 
“epidemia” cessa. A cidade volta à normalidade. Mas é necessário fazer mais uma experiência:

[...] una prova, ma timida e cautelosa; una prova quanto più fosse possibile "giusta". 117

Duas semanas depois, com a meticulosidade de um cientista que leva adiante um experimento, o protagonista procura uma criança que conhece, nascida com uma doença deformante, e repete o gesto diante dela: a criança morre com um sorrido no rosto. Aí está a tremenda confirmação, é ele mesmo o agente da morte, ou melhor, ele é a própria morte, que mata as pessoas sem qualquer sentimento de inimizade ou remorso:

Ero io, ero io; la morte ero io; la avevo lì, nelle due dita e nel fiato; potevo far morire tutti. ${ }^{118}$

Desesperado, o protagonista, que também é o narrador, sai pelas ruas da cidade e, passando em frente aos portões do hospital, encontra ali um grupo de médicos reunidos e decide fazer mais uma experiência repetindo o gesto diante de um deles: o resultado é sempre o mesmo. Enquanto morre, o médico grita "L’epidemia! L'epidemia!". ${ }^{119}$ Os presentes fogem apavorados e o homem continua caminhando pelas ruas da cidade até se encontrar diante do espelho de uma loja. Sem se conformar com esta triste realidade, e talvez para provar que não havia sido ele, que ele não poderia ter provocado aquelas mortes, o protagonista, no espelho, faz o gesto experimentando-o sobre si mesmo:

\footnotetext{
117 “[...] uma experiência, mas tímida e cautelosa; uma experiência que fosse o quanto possível “justa””. Ibid., p. 640.

118 "Era eu, era eu; a morte era eu; eu a tinha ali, nos dois dedos e no sopro; podia matar todos." Ibid., p. 642

119 “A epidemia! A epidemia!” Ibid., p. 645.
} 
M'intravidi per un attimo appena in quello specchio, con occhi che io stesso non sapevo più come guardarmeli, così cavati dentro. Com'erano nella faccia da morto; poi, come se il vuoto mi avesse inghiottito, o colto una vertigine, non mi vidi più; toccai lo specchio, era lì, davanti a me, lo vedevo e io non c'ero; mi toccai, la testa, il busto, le braccia; mi sentivo sotto le mani il corpo, ma non me lo vedevo più e neanche le mani con cui me lo toccavo; eppure non ero cieco; $[\ldots]^{120}$

Até esse momento, a novela se desenvolve de maneira praticamente linear. O protagonista, mais uma vez sem nome, depois da descoberta de seu dom fatal, não quer acreditar e procura razões, tenta encontrar uma explicação diferente para a implacável realidade que o oprime. O elemento surreal, se assim pode ser chamado (e neste caso talvez seja mais comparável ao realismo mágico de Bontempelli ${ }^{121}$ e mais tarde à obra de Dino Buzzati), é colocado em dúvida pela racionalidade do narrador que, além de não acreditar, não consegue se ver como o anjo da morte. A novela poderia tranqüilamente terminar neste ponto, com a morte do personagem. Mas os personagens de Pirandello, desta fase, não morrem simplesmente; para o autor a vida "non conclude"122 e vai além da própria morte.

O tema do espelho, aqui, liga-se diretamente ao da dissolução da forma. O espelho não reflete mais o aspecto deformante da realidade, onde a vida é aprisionada em formas que impedem seu natural e desejável fluir, e se transforma em uma superfície cega, escapando da forma, ou seja, a vida continua dentro da morte, e a consciência individual, espelhando-se em si mesma, está pronta para uma dissolução completa.

\footnotetext{
120 "Vi-me apenas por um instante naquele espelho, com olhos que eu mesmo não sabia mais como olhar, de tão encovados. Como se fossem do rosto de um morto; depois, como se o vazio vivesse me engolido, ou eu vivesse tido uma vertigem, não me vi mais; toquei o espelho, estava ali, na minha frente, eu o via e não estava lá; toquei-me, a cabeça, o peito, os braços; sentia o corpo sob minhas mãos, mas não o via mais e nem as mãos com que o tocava; mas eu não estava cego; [...] Ibid., p. 646.

121 M. Bontempelli, L' avventura novecentista: selva polemica, 1926-1938 : dal realismo magico allo stile naturale, soglia della terza epoca, Firenze, Vallecchi, 1938.

${ }^{122}$ PIRANDELLO, Luigi. Uno, nessuno e centomila. Op. cit., p. 755.
} 
A novela, que havia começado com tons realistas, passa da incômoda aceitação por parte do narrador de seu dom mortal a uma atmosfera de pesadelo. Quando o corpo do narrador desaparece, porém, a natureza exterior persiste. A morte é uma força gentil que anula o tempo e se completa na dissolução total do $\mathrm{Eu}$, sem, no entanto, anular a consciência. Esta dissolução acontece como uma espécie de renascimento tão absoluto que a indeterminação da forma não parece mais uma ameaça, mas uma tentação.

A essência imaterial que resulta da experiência do protagonista soprando sobre si mesmo, percorre a cidade em direção ao campo. A integração com a natureza, já experimentada pelo protagonista do romance Uno, nessuno e centomila, Vitangelo Moscarda, e demonstrada necessária para a reconstituição do Eu na maioria das últimas novelas, realiza-se plenamente e anula a relação tempo-espaço: a visão de uma garota, sentada sob oleandros, remete o protagonista a uma imagem talvez perdida na memória. O tempo, a forma, o sofrimento e a morte não existem mais e o olhar do narrador torna-se "l'aria stessa che la carezzava senza che lei se ne sentisse toccare."123

\footnotetext{
123 "o próprio ar que a acariciava sem que ela se sentisse tocar” PIRANDELLO, Luigi. Soffio. In: Novelle per un anno. Op. cit., p. 647.
} 


\section{Considerações finais}

Ao final deste itinerário de exploração e descrição dos motivos e formas que caracterizam a ampla, variada e às vezes impenetrável, tanto quanto sugestiva, produção novelística de Pirandello, algumas considerações se impõem.

Em primeiro lugar, é preciso enfatizar que estamos diante de um autor de inúmeros recursos e infinitas surpresas, e devemos, por essa razão, lê-lo com a honestidade e a paciência que sua obra exige, sem preconceitos e longe de tentações instrumentais e hipóteses extravagantes que, ditadas pela originalidade ou pela "modernidade", possam determinar um percurso que nos afaste dos reais objetivos do autor.

Em segundo lugar, devemos insistir que essa obra extraordinariamente renovadora é o modo como Pirandello experimenta a única abordagem possível para se aproximar de uma condição social e existencial ainda em formação, sujeita a mudanças imprevisíveis, ou seja, a desobediência à norma, à ordem, ao classicismo e à literariedade, com a utilização de estruturas retóricas novas, anti-literárias e anti-clássicas.

Pirandello assume um código de escrita adequado à tensão do personagem e da atmosfera em que ele se movimenta, e sem se preocupar em ser aderente à realidade, é centrado na palavra capaz de exprimir a inquietude do paradoxo, do irreal, do absurdo que caracterizam e autenticam o labirinto da alma humana e das relações sociais. Trata-se de um 
método muito particular para a investigação da alma humana; um método mais do que empírico, este "método Pirandello" procura examinar exaustivamente todas as situações a que seus personagens possam ser submetidos para colocar diante de nossos olhos o grande afresco em que o grito da humanidade ferida e desiludida penetra profundamente em nós para não mais nos abandonar.

A força mais íntima e persuasiva de sua obra, principalmente nas novelas, está na carga humana que ele coloca em seus personagens, na sua profunda piedade pelos fracos, os incompreendidos, os esquecidos, as vítimas da violência, os sem identidade e sem destino. Preocupado em fazer "falar" o personagem e retratar sua caótica e desesperada condição existencial, Pirandello certamente não cultiva o "escrever bem”, a página harmoniosa, o estilo formalmente elaborado. Seu texto é convulso, desordenado, tortuoso, irreverente, às vezes humilde, negligente, de uma simplicidade extrema, de uma transparência singular; despojado, mas sempre luminoso e nunca difícil: escreve como falam e agem seus delirantes personagens. É um escritor que pensa no serviço que sua obra pode prestar ao dizer aos outros homens algo de não efêmero, importante e sem ingenuidades morais. Em 1935, um ano antes de sua morte, Pirandello escreveu:

Ho sempre riconosciuto tutto, e più che mai gli uomini, dovunque. M'è sempre bastato guardarli negli occhi, forse solo un pochino più addentro di quanto essi non s'aspettassero, in modo da superare il vano schermo delle convenzioni dietro cui ciascuno vuol sentirsi sicuro della sua diversità. Uomini, tutti, come me; nonostante i linguaggi, le tradizioni, le nature, che avrebbero dovuto farmeli lontani e stranieri. E che posso fare io se il mio solo interesse reale è per gli uomini? quali veramente sono nel loro segreto $?^{124}$

\footnotetext{
124 "Sempre reconheci tudo, e antes de mais nada os homens de todos os lugares. Sempre me bastou olhá-los nos olhos, talvez um pouquinho mais do que estes esperassem, de modo a superar a vã proteção das convenções por trás das quais cada um pretende se sentir seguro de sua diversidade. Homens, todos, como eu, apesar das
} 
Este foi o objetivo que ele perseguiu, com obstinada e apaixonada coerência, da primeira à última novela, em uma pesquisa ininterrupta em que houve tempo apenas para esboçar os primeiros resultados. Dissecando repetidamente a alma humana, Pirandello foi além dos males de seu tempo, sempre procurando encontrar uma solução ou um alívio que seja para a alienação, a obscuridade, a precariedade, a inquietude e a angústia existencial do homem. Em sua etapa final, desencantado e desiludido, ele toma outros caminhos, pois se o corpo vestido pela forma não parece encontrar paz e a máscara não se deixa arrancar, fraturando-se e se recompondo em novas e cada vez mais terríveis máscaras, talvez o espírito, em conjunção com a natureza pudesse finalmente sentir-se uno e reparado. Esta é a direção tomada por Pirandello nas últimas novelas: a morte como desejo, a solidão como recompensa e toda a natureza mítica para nos reconfortar.

Embora as últimas novelas, juntamente com as peças míticas, pareçam um corpo estranho dentro da novelística do autor, com personagens sem nome, onirismo exacerbado, longos momentos de introspecção, traços surrealistas, alegorias e dissolução, elas não têm a carga negativa que lhes poderia ser atribuída. Também não devem ser confundidas com evasão, negação da realidade ou escapismo, pois estes elementos são, antes de mais nada, apenas algumas das hipóteses que Pirandello testava em sua tentativa de resgatar o real sentimento de cada um, a unidade espiritual a que o homem aspira e da qual necessita para viver em paz consigo mesmo.

A mensagem final ficou sem conclusão; ainda seria preciso um estudo mais aprofundado e minucioso. Mas como o próprio Pirandello escreveu: a vida "non conclude..." 


\section{REFERÊNCIAS BIBLIOGRÁFICAS}

\section{OBRAS DE LUIGI PIRANDELLO}

Novelle per un anno. Edizione "I Meridiani" a cura di Mario Costanzo. Milano: Mondadori, 3 vol., 2007.

Saggi e interventi. Edizione "I Meridiani" a cura di Ferdinando Taviani. Milano: Mondadori, 2006.

L’umorismo. Roma: Tascabili Economici Newton, 1993.

Carteggi inediti. A cura di S. Zapulla Muscarà. Roma: Bulzoni, 1980.

Saggi, poesie e scritti varii. Milano: Mondadori, 1960.

Tutti i romanzi. Milano: Mondadori, 2 vol., 1949.

Maschere nude. Milano: Mondadori, 4 vol., 1949.

\section{SOBRE O AUTOR E SUA OBRA}

BARILLI, Renato. Pirandello. Una rivoluzione culturale. Milano: Arnoldo Mondadori Editore, 2005.

La linea Svevo-Pirandello. Milano: Arnoldo Mondadori Editore, 2003.

BORSELLINO, Nino. Ritratto e immagini di Pirandello. Roma-Bari: Editori Laterza, 1991. BOSCHIGGIA, Elisabetta. Guida alla lettura di Pirandello. Milano: Mondadori, 1986. 
BOSI, Alfredo. Céu, inferno. Ensaios de crítica literária e ideológica. São Paulo: Editora Ática, 1988.

CAMBON, Glauco (org.). Pirandello. A collection of critical essays. Hew Jersey: PrenticeHall, 1967.

CAMILLERI, Andrea. Biografia del figlio cambiato. Milano: Rizzoli, 2000.

CANTELMO, Marinella Di lemmi del riso e altri saggi su Pirandello. Ravenna. Longo Editore Ravenna, 2004.

CESERANI, Remo. Il fantastico. Bologna: Il Mulino, 1996.

DEBENEDETTI, Giacomo. Il romanzo del Novecento. Milano: Garzanti, 1983. Italiani del novecento. Firenze: Giunti, 1995.

DE CASTRIS, A. Leone. Storia di Pirandello. Bari: Editori Laterza, 1962.

DE CASTRIS, Arcangelo Leone. Il decadentismo italiano. Bari: Editori Laterza, 1989.

GRIMALDI, Emma. Il labirinto e il caleidoscopio. Percorsi di letture tra le "Novelle per un anno" di Luigi Pirandell. Soveria Mannelli: Rubbettino Editore, 2007.

GUARAGNELA, Pasquale. Un moderno viaggio agl'inferi. Indagini tematiche su Uno, nesuno e centomila. In: Ferdinado Pappalardo (org.). La torre abolita. Saggi sul romanzo italiano del Novecento. Bari: Edizioni Dedalo, 1988.

LAURETTA, Enzo (org.). Pirandello e la lingua. Milano: Mursia Editore, 1994.

LUPERINI, Romano Pirandello. Roma-Bari: Editori Laterza, 2005. Introduzione a Pirandello. Roma-Bari: Laterza, 1992.

MACCHIA, Giovanni. Premessa. In: Luigi Pirandello, Novelle per un anno, Edizione "I Meridiani” a cura di Mario Costanzo. Milano: Mondadori, 3 vol., vol. 1, tomo 1, 2007. MANOTTA, Marco. Luigi Pirandello. Milano: Bruno Mondadori, 1998.

MAURO, Sérgio. Pirandello e Machado de Assis: um estudo comparado. Dissertação de Mestrado. Faculdade de Filosofia, Letras e Ciências Humanas. São Paulo, 1989.

MAZZALI, Ettore. Luigi Pirandello. Roma: La nuova Italia, 1974.

MAZZACURATI, Giancarlo. Pirandello nel romanzo europeo. Bolognga: Il Mulino, 1995. 
MILIOTO, Stefano (org.), Le novelle di Pirandello, Atti del Convegno di Studi, Agrigento, 610 dicembre 1979. Agrigento: Edizioni del Centro Nazionale di Studi, 1980.

NOBILI, Claudia Sebastiana. La materia del sogno. Pirandello tra racconto e visione. Pisa: Giardini Editori e Stampatori, 2007.

PETRONIO, Giuseppe. Le novelle surrealistiche di Pirandello. In: S. Milioto (org.), Le novelle di Pirandello, Atti del Convegno di Studi, Agrigento, 6-10 dicembre 1979. Agrigento: Edizioni del Centro Nazionale di Studi, 1980.

PUGLISI, Filippo. L’arte di Luigi Pirandello. Messina-Firenze: Casa Editrice G. D’Anna, 1958.

Pirandello e la sua lingua. Rocca San Casciano: Cappelli Editore, 1962.

PUPO, Ivan. Interviste a Pirandello. "Parole da dire, uomo, agli altri uomini". Soveria Mannelli: Rubbettino Editore, 2002.

RADCLIFF-UMSTEAD, Douglas. The mirror of our anguish. A study of Luigi Pirandello's narrative writings. New Jersey: Associated University Presses, 1978.

SCIASCIA, Leonardo. Pirandello e la Sicilia. Caltanisseta-Roma: Salvatore Sciascia Editore, 1968.

STARKIE, Walter. Luigi Pirandello. New York,:E. P. Dutton \& CO., 1926.

TERRACINI, Benvenuto. Le "Novelle per un anno" di Luigi Pirandello. In: Analisi stilistica. Milano: Feltrinelli, 1966.

TILGHER, Adriano. Studi sul teatro contemporaneo. Roma: Libreria di Scienze e Lettere, 1923.

TUSCANO, Pasquale. L'identità impossibile. L'opera di Luigi Pirandello. Napoli: Loffredo, 1989.

III - OBRAS DE REFERÊNCIA

ADORNO, Theodor W. Notas de literatura I. São Paulo: Editora 34, 2003. 
ASOR ROSA, Alberto. La novella occidentale dalle origini ad oggi. Roma: Edizioni Moderne Canesi, 1960. . Genus italicum. Torino: Einaudi, 1997.

AUERBACH, Erich. Mimesis. São Paulo: Editora Perspectiva, 2001.

BAKHTIN, Mikhail. Estética da criação verbal. São Paulo: Martins Fontes, 2003.

BAKHTIN, Mikhail. Problemas da poética de Dostoiévski. Rio de Janeiro: Ed. ForenseUniversitária, 1981.

BARTHES, Roland. O grau zero da escrita. São Paulo: Martins Fontes, 2004.

BERMAN, Marshall. Tudo que è sólido desmancha no ar. São Paulo: Companhia das Letras, 1986.

BARTHES, Roland. O grau zero da escrita. São Paulo: Martins Fontes, 2004.

BENEDETTI, Carla. La soggettività nel racconto. Napoli: Liguori Editore, 1984.

BERGSON, Henri. O riso. Rio de Janeiro: Zahar Editores, 1983.

CIRILLO, Silvana (org.). Il comico nella letteratura italiana. Roma: Donzelli Editore, 2005.

BONTEMPELLI, Massimo. L' avventura novecentista: selva polemica, 1926-1938: dal realismo magico allo stile naturale, soglia della terza epoca. Firenze: Vallecchi, 1938.

FERRONI, G., et al. Storia e testi della letteratura italiana - Guerre e fascismo (1910-1945). Milano: Mondadori Universtà, 2004.

GENETTE, Gérard. Figure III. Discorso del racconto. Torino: Einaudi, 2006.

GOTLIB, Nádia Batella. Teoria do conto. São Paulo: Editora Ática, 2004.

JOUVE, Vincent. A leitura. São Paulo: Editora UNESP, 2002.

LEITE, Ligia Chiapini Moraes, O foco narrativo. São Paulo: Editora Ática, 2005.

LUPERINI, Romano. L'autocoscienza del moderno. Napoli: Liguori Editore, 2005.

MAYER, Arno J. A força da tradição. São Paulo: Companhia das Letras, 1990.

MERLEAU-PONTY, Maurice. Senso e non senso. Milano: Il Saggiatore, 2004.

NUVOLI, Giuliana (org.). La novella italiana. Milano: Bruno Mondadori, 2000.

PABST, Walter. La novela corta en la teoría y en la creación literaria. Madrid: Editorial Gredos, 1972. 
SALINARI, Carlo. Miti e coscienza del decadentismo italiano. Milano: Feltrinelli Editore, 1984.

SEGRE, Cesare. Avviamento all'analisi del testo letterario. Torino: Einaudi, 1985.

SICILIANO, Enzo. Racconti italiani del Novecento. Milano: Mondadori, 2001 
ANEXOS 


\section{Anexo 1: Gráfico}

Número de novelas publicadas por ano

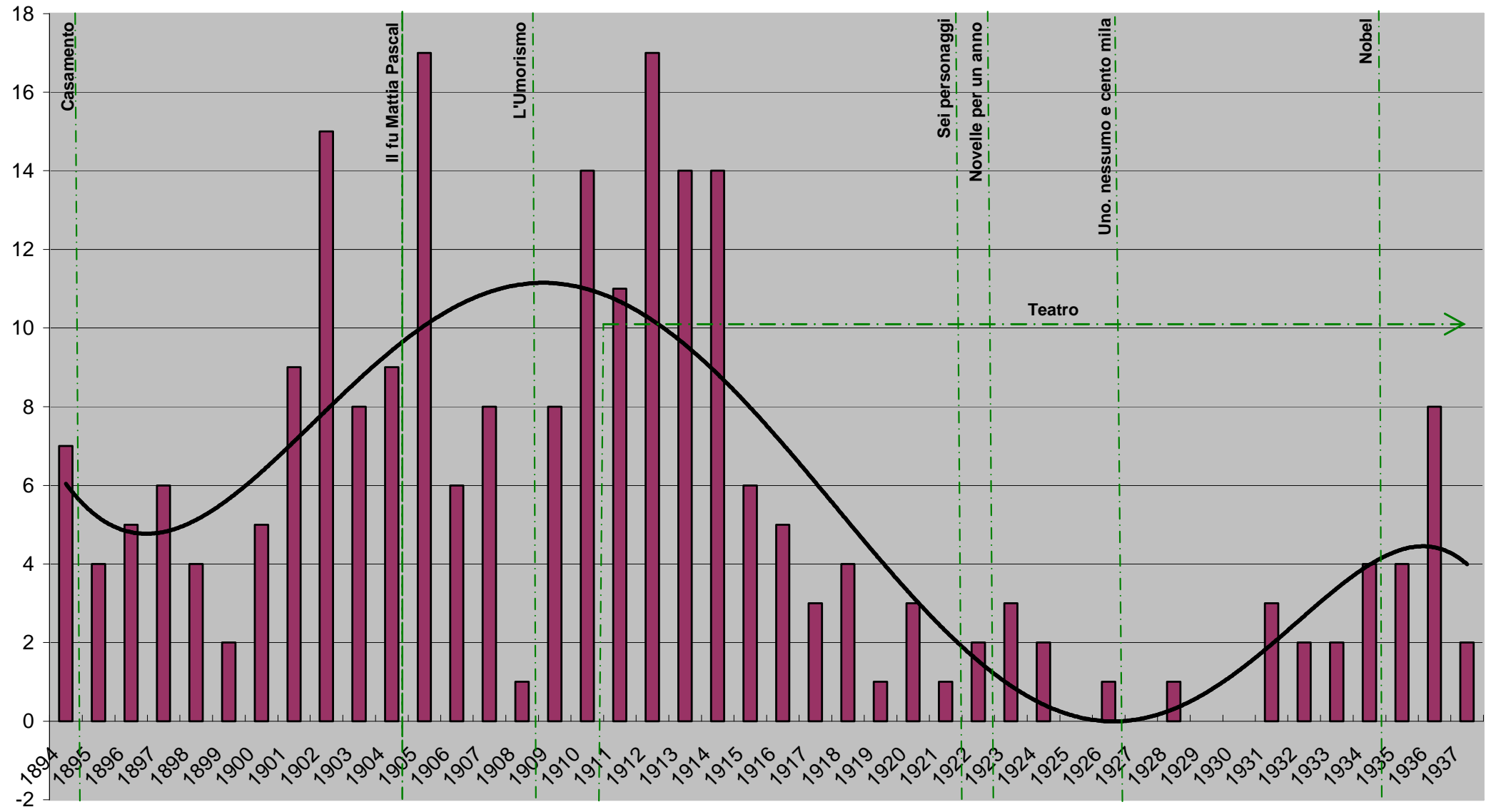


Anexo 2

Novelas publicadas entre 1931 e 1936.

\begin{tabular}{|l|l|l|}
\hline \multicolumn{1}{|c|}{ Título } & Data de Publicação & \multicolumn{1}{c|}{$\begin{array}{c}\text { Volume das } \\
\text { Novlle per un anno }\end{array}$} \\
\hline Uno di più & $1 / 2 / 1931$ & Berecche e la guerra \\
\hline Soffio & $1 / 7 / 1931$ & Berecche e la guerra \\
\hline I muricciuoli, un fico, un uccellino & $18 / 10 / 1931$ & Testi estravaganti \\
\hline Cinci & $1 / 6 / 1932$ & Berecche e la guerra \\
\hline Lucilla & $26 / 6 / 1932$ & Berecche e la guerra \\
\hline Sgombero & $00 / 00 / 1933$ & Appendice \\
\hline I piedi sull'erba & $20 / 4 / 1934$ & Berecche e la guerra \\
\hline Di sera un geranio & $6 / 5 / 1934$ & Berecche e la guerra \\
\hline Un'idea & $2 / 6 / 1934$ & Berecche e la guerra \\
\hline Una giornata & $24 / 9 / 1935$ & Una giornata \\
\hline La prova & $22 / 10 / 1935$ & Una giornata \\
\hline La casa dell'agonia & $6 / 11 / 1935$ & Una giornata \\
\hline Fortuna d'esser cavallo & $23 / 11 / 1935$ & Una giornata \\
\hline Una sfida & $00 / 00 / 1936$ & Una giornata \\
\hline Il chiodo & $21 / 1 / 1936$ & Una giornata \\
\hline Vittoria delle formiche & $2 / 2 / 1936$ & Una giornata \\
\hline Visita & $16 / 6 / 1936$ & Una giornata \\
\hline La tartaruga & $1 / 8 / 1936$ & Una giornata \\
\hline C'è qualcuno che ride & $7 / 11 / 1936$ & Una giornata \\
\hline Effetti d'un sogno interrotto & $9 / 12 / 1936$ & Una giornata \\
\hline Il buon cuore & $16 / 2 / 1937$ & Una giornata \\
\hline
\end{tabular}


Anexo 3

Bio-bibliografia

Pirandello "novellaro"

1867

Luigi Pirandello nasce em 28 de junho, filho de Stefano Pirandello, de família lígure, e Caterina Ricci-Gramitto, nas proximidades de Girgenti (hoje Agrigento), na Sicília.

\section{0-1879}

Recebe instrução elementar em casa e depois de freqüentar dois anos do Instituto Técnico passa ao Ginásio seguindo os estudos clássicos.

\section{$1880-1883$}

A família transfere-se para Palermo, onde ele prosegue os estudos. Escreve algumas poesias.

1884

Publica sua primeira novela "Capanetta" (A) em "La Gazzetta del popolo della domenica" (Palermo).

1886

Terminada a escola média, volta para Girgenti. Trabalha com o pai nas minas de enxofre. Inscreve-se na Faculdade de Letras e na de Direito da Universidade de Palermo. Fica noivo da prima Paolina, alguns anos mais velha do que ele.

1887

Transfere-se para a Faculdade de Letras da Universidade de Roma.

1889

Devido a uma discussão com o professor de latim, é obrigado a abandonar a Universidade de Roma e inscreve-se na Universidade de Bonn. Rompe o noivado com Paolina. Publica, em Palermo, seu primeiro livro de poesias (Mal Giocondo). 


\section{0-91}

Ainda em Bonn, conhece e se enamora de Jenny Schulz-Lander para quem dedica seu segundo livro de poesias (Pasqua di Gea). Traduz para o italiano as Elegie Renane, de Goethe. Gradua-se em Filologia românica com uma tese sobre o dialeto de Girgenti.

1892

Voltando à Itália, passa alguns meses em Girgenti e se transfere para Roma. Publica sua segunda novela - "La ricca" (A).

1893

Incentivado por Luigi Capuana a tentar a narrativa, escreve seu primeiro romance (Marta Ayala) que publicará, com o título de L'esclusa, em 1901.

\section{4}

Casa-se em Girgenti com Maria Antonietta Portolano, indo morar definitivamente em Roma. Publica seu primeiro livro de novelas (Amori senza amore) composto das novelas "L'onda" (A), "La signorina" (A) e "L'amica delle mogli" (A). Publica em jornais e revistas outras quatro novelas. ${ }^{125}$

1895

Escreve seu segundo romance (Il turno) que sairá em 1902 e publica as Elegie renane (poesia). Nasce seu primogênito Stefano. Publica em jornais e revistas quatro novelas. ${ }^{126}$

1896

Publica a tradução das Elegie romane de Goethe e o ensaio Un preteso umorista del secolo XIII. As novelas publicadas neste ano são cinco. ${ }^{127}$

\section{7}

Nasce a filha Rosalia (Lietta). Começa a dar aulas no Istituto Superiore di Magistero di Roma. Publica seis novelas. ${ }^{128}$

${ }^{125}$ Concorso per referendario al Consiglio di Stato (VD); Se... (SN); Le tre carissime (VD); I galletti del bottaio (A).

${ }^{126}$ In corpore vili (VD); Il "no" di Anna (A); Dialoghi fra il Gran Me e il piccolo me (A); Il nido (A).

${ }^{127}$ Natale sul Reno (A); Chi fu? (A); Sole e ombra (R); Visitare gl'infermi (DM); Sogno di natale (A). 
1898

Funda com Ugo Fleres e Italo Falbo a revista semanal literária "Ariel”. Publica as novelas "Incontro" - depois renomeada "La veglia" (IS) -, "Disdetta" - depois renomeada "La disdetta di Pitagora" (VD) -, "La scelta" (A) e "Padron Dio" (UG)

\section{9}

Nasce o filho Fausto. Publica o ensaio L'azione parlata e as novelas "Dono della Vergine Maria" (US) e "La maestrina Boccarmè" (TT).

\section{0}

Publica cinco novelas: "Scialle nero" (SN), "Alberi cittadini" (A), "La paura del sonno" (G), "Lumìe di Sicilia" (VD), "Prima notte" (SC).

\section{1}

Publica várias novelas, ${ }^{129}$ o volume de poesia Zampogna e o romance L’esclusa, este último em capítulos no jornal "La tribuna".

\section{2}

Reune em dois livros, Beffe della vita e della morte e Quand'ero matto, as novelas escritas nos anos anteriores e mais algumas inéditas. ${ }^{130}$ Publica o romance Il turno.

\section{3}

Ano particularmente difícil para Pirandello: a mina de enxofre, na qual seu pai havia empregado todo seu capital mais o dote de Antonietta, alaga-se levando a família à ruína. Antonietta fica semi-paralisada com a notícia e desenvolve uma forma grave de paranóia da qual nunca mais se curará. Para enfrentar a situação econômica, Pirandello é obrigado a dar aulas particulares. Neste ano publica sete novelas ${ }^{131}$, pedindo aos editores pagamento por elas.

\footnotetext{
${ }^{128}$ Vexilla regis (V); La paura (A); Il giardinetto lassù (IS); Le dodici lettere (A); Creditor galante (A); Acqua e lì (TT).

${ }^{129}$ Il fumo (SN); La levata del sole (VD); Nenia (R); Notizie dal mondo (US); Prudenza (A); Il vecchio Dio (VD); Con altri occhi (M); E due! (SN); Marsina stretta (TT).

${ }^{130}$ Lontano (M); Pallottoline! (G); Quand'ero matto... (VD); Un goj (R); Un invito a tavola (VD); Un'altra allodola (G); Gioventù (V); La berretta di Padova (M); Il figlio cambiato (DC); Tanino e Tanotto (VD); Il dovere del medico (VN); Alla zappa! (IS); Amicissimi (SN); Il corvo di Mìzzaro (IS); Al valor civile (VD).

${ }^{131}$ La disdetta di Pitagora (VD); La signora Speranza (A); Come gemelle (TT); Il marito di mia moglie (TT); La balia (IS); Il ventaglino (SN); Il tabernacolo (SN).
} 
1904

Publica Il fu Mattia Pascal, seu primeiro romance de sucesso, e o livro de novelas Bianche e nere. $^{132}$

1905

È publicada a tradução em alemão de Il fu Mattia Pascal. As novelas publicadas são dezessete. $^{133}$

1906

Começa a escrever o romance I vecchi e $i$ giovani. Publica pela prestigiada editora Treves o livro de novelas Erma bifronte. As novelas inéditas são: "L'uscita del vedovo" (VN); "Personaggi" (Agg); "Richiamo all'obbligo" (G); "Tutto per bene" (VN); "La toccatina" (VN); "Nel dubbio" (NC)

1907

Publica as novelas "Distrazione" (VN); “Tra due ombre" (M); "La vita nuda" (VN); "Dal naso al cielo" (NC); "La corona" (NC); "Un cavallo nella luna" (DM); "Pari” (VN); "Volare" (US)

\section{8}

Para a nomeação de professor efetivo, publica seu principal ensaio, L'umorismo, e outro volume de ensaios - Arte e scienza. É nomeado para cátedra de "Lingua italiana, stilistica e precettistica e studio dei classi, compresi i greci e i latini nelle migliori versioni”, no Istituto Superiore di Magistero di Roma. Publica uma única novela: "Il guardaroba dell'eloquenza" (G).

\footnotetext{
132 Formalità (SN); Nel segno (VN); La veglia (IS); La buon'anima (VN); Sua Maestà (R); Le medaglie (M); Una voce (IS); La mosca (M); La fedeltà del cane (VN).

${ }^{133}$ La Messa di quest'anno (A); Il sonno del vecchio (M); In silenzio (IS); Fuoco alla paglia (VN); L'altro figlio (IS); L'eresia catara (M); I tre pensieri della sbiobbina (R); Lo scaldino (M); Senza malizia (VN); Di guardia (US); La casa del Granella (VN); Acqua amara (VN); Tirocinio (G); Pallino e Mimì (VN); Va bene (IS); Le sorprese della scienza $(\mathrm{M})$; Guardando una stampa $(\mathrm{G})$.
} 
1909

Inicia a colaboração com o jornal "Corriere della sera", que se estenderá até 1936. Publica a primeira parte do romance $I$ vecchi $e$ i giovani. As novelas publicadas este ano são: "L'ombrello" (V); "Due letti a due" (G); "Stefano Giogli, uno e due" (A); "Difesa del Mèola" $(\mathrm{SN})$; "Mondo di carta" (M); "La giara" (G); "L'illustre estinto" (G); "Il lume dell'altra casa" (V). Começa a escrever aquile que será seu último romance: Uno, nessuno e centomila.

1910

Estréia como autor teatral em 9 de dezembro, em Roma, com os atos únicos Lumìe di Sicilia e La morsa, retirados das novelas homônimas. Publica quatorze novelas. ${ }^{134}$

\section{1}

Publica o romance Suo marito, mais tarde renomeado Giustino Roncella nato Boggiòlo. No "Corriere della sera" saem algumas de suas novelas mais conhecidas. ${ }^{135}$

\section{2}

Sai o livro de novelas Terzetti e seu último volume de poesias Fuori di chiave.Continua a publicar novelas em jornais e revistas. ${ }^{136}$

\section{$1913-1915$}

Sai a edição completa de I vecchi e i giovani (dois volumes). Com a entrada em guerra da Itália, o filho Stefano parte como voluntário e cai prisioneiro dos austríacos; o outro filho, Fausto, também se alista no exército italiano. Em Girgenti, morre a mãe do autor. A doença de Antonietta agrava-se. Neste período, dedica-se a escrever para o teatro, retirando os argu-

\footnotetext{
${ }^{134}$ Ignare (V); Non è una cosa seria $(\mathrm{G})$; L'uccello impagliato (V); Musica vecchia (NC); Benedizione (NC); Pensaci, Giacomino! (G); Il professor Terremoto (US); Lo spirito maligno (IS); La lega disciolta (G); Leviamoci questo pensiero (V); Lo storno e l'angelo Centuno (NC); Il viaggio (V); La morta e la viva (G); "Leonora, addio" (V).

${ }^{135}$ Paura d'esser felici (DM); Felicità (V); Zafferanetta (V); L'uomo solo (US); La cassa riposta (US); I fortunati $(\mathrm{SN})$; La patente (R); Il libretto rosso (V); La tragedia d'un personaggio (US); "Ho tante cose da dirvi..." (C); Canta l'epistola (R).

${ }^{136}$ I nostri ricordi (US); Risposta (SN); L'avemaria di Bobbio; (R); Certi obblighi (NC); Nenè e Ninì (R); O di uno o di nessuno (R); "Superior stabat lupus" (NC); La trappola (US); Il coppo (US); La verità (US) Maestro Amore (A); Notte (R); Chi la paga (NC); L'imbecille (R); Tu ridi (TT); I due compari (TT); Ciàula scopre la luna $(\mathrm{NC})$.
} 
mentos principalmente das novelas que, no entanto, não pára de escrever e publicar como obras autônomas. ${ }^{137}$

\section{6}

A atividade teatral é constante, o que faz com que a escrita e publicação das novelas diminua. ${ }^{138}$ Publica o romance Si gira..., depois renomeado Quaderni di Serafino Gubbio operatore.

\section{7}

Grande atividade teatral. Publicação do volume de novelas $E$ domani, lunedì... As novelas inéditas são poucas. ${ }^{139}$

\section{8}

Sai o livro de novelas Un cavallo nella luna e o primeiro volume da reunião de seus textos teatrais Maschere nude. A atividade de novelista é pequena. ${ }^{140} \mathrm{O}$ filho Stefano é libertado.

$1919-1920$

Dedicando-se cada vez mais ao teatro, não tem mais o tempo necessário para as novelas. ${ }^{141}$ Mesmo assim, saem dois volumes de novelas Berecche e la guerra e Il carnevale dei morti.

\section{1}

Encena sua peça teatral mais conhecida na Itália e no exterior e, talvez, a mais importante: Sei personaggi in cerca d'autore. Publica apenas uma novela: "La distruzione dell'uomo" (M)

\footnotetext{
1371913 - Candelora (C); Il bottone della palandrana (TT); La veste lunga (US); "Requiem aeternam dona eis, Domine" (R); Quando s'è capito il gioco (UG); Tutt'e tre (TT); L'abito nuovo (DM); Nel gorgo (NC); La Madonnina (M); Male di luna (NC); La rallegrata (R); Da sé (C); Rondone e Rondinella (DM); Il capretto nero (DM). 1914 - I pensionati della memoria (DM); La liberazione del re (TT); Mentre il cuore soffriva (C); L'ombra del rimorso (TT); Il treno ha fischiato... (US); Sopra e sotto (R); Filo d'aria (TT); Zia Michelina (US); Un matrimonio ideale (TT); Un ritratto (C); Servitù (C); La realtà del sogno (C); La rosa (C); Zuccarello distinto melodista (C). 1915 - La mano del malato povero (V); Nell'albergo è morto un tale (C); Romolo (C); Visto che non piove... (SN); Il vitalizio (VD); Colloqui coi personaggi (A).

${ }^{138}$ Il signore della nave (C); La carriola (C); La camera in attesa (C); I due giganti (A); Piuma (C).

${ }^{139}$ Donna Mimma (DM); Il gatto, il cardellino e le stelle (DM); La signora Frola e il signor Ponza suo genero (UG).

${ }^{140}$ La cattura (G); Quando si comprende (DM); La maschera dimenticata (IS); La morte addosso (IS).

${ }^{141} 1919$ - Jeri e oggi (NC). 1920 - Il pipistrello (SN); Rimedio: la Geografia (SN); Pena di vivere così (IS)
} 
$1922-1925$

Começa a organização do projeto Novelle per un anno, que deixará incompleto e sobre o qual adverte no primeiro volume: "Una novella al giorno, per tutt'un anno, senza che dai giorni, dai mesi o dalle stagioni nessuna abbia tratta la sua qualità". Em 1922 saem os primeiros quatro volumes. Neste período, as novas novelas são poucas. ${ }^{142}$

\section{6}

Sai seu último romance - Uno, nessuno e centomila -, 15 anos depois do início da escrita. Apenas uma novela inédita é publicada: "Pubertà" (V).

\section{$1927-1934$}

Continua a atividade teatral e a reorganização de sua obra, o que não lhe permite dedicar-se às novelas. ${ }^{143}$ Em novembro de 1934, a Real Academia da Suécia confere-lhe o prêmio Nobel de literatura.

\section{5}

É grande o desejo de Pirandello de completar o projeto das Novelle per un anno. Tanto que escreve a Aldo Borrelli, editor do "Corriere della sera": "Vi mando, appena tornato da New York, questa novella, e Vi prometto che riprenderò regolarmente la mia collaborazione perché è ferma mia intenzione compire le mie Novelle per un anno." 144

\section{6}

Sempre no "Corriere della sera", publica suas últimas novelas, deposi reunidas no volume póstumo das Novelle per un anno - Una giornata. ${ }^{145}$ Morre em 10 de dezembro, de pneumonia, deixando incompletas as Novelle per un anno e a peça teatral I giganti della montagna.

\footnotetext{
1421922 - La fede (M); Niente (M); 1923- Fuga (NC); Ritorno (TT); Un po' di vino (TT); 1924 - Resti mortali (DM); Sedile sotto un vecchio cipresso (DM).

${ }^{143} 1928$ - Spunta un giorno (V); 1931 - Uno di più (BG); Soffio (BG); 1932 - Cinci (BG); Lucilla (BG); 1933 Sgombero (A); La vendetta del cane (DM); 1934 - Berecche e la guerra (BG); I piedi sull'erba (BG); Di sera un geranio (BG); Un'idea (BG).

${ }^{144}$ PIRANDELlo, Carteggi inediti, cit., p. 241.

${ }^{145}$ Una sfida (UG); Il chiodo (UG); Vittoria delle formiche (UG); Visita (UG); La tartaruga (UG); C'è qualcuno che ride (UG); Effetti d'un sogno interrotto (UG); Il buon cuore (UG).
} 